\title{
Biodiversity hotspot in cold waters: a review of the genus Cuthonella with descriptions of seven new species (Mollusca, Nudibranchia)
}

\author{
Tatiana A. Korshunova \\ Koltzov Institute of Developmental Biology RAS, 26 Vavilova Str., 119334, Russia
}

Nadezhda P. Sanamyan

Kamchatka Branch of Pacific Geographical Institute FEB RAS, Partizanskaya Str. 6, 683000

Petropavlovsk-Kamchatsky, Russia

\section{Karen E. Sanamyan}

Kamchatka Branch of Pacific Geographical Institute FEB RAS, Partizanskaya Str. 6, 683000

Petropavlovsk-Kamchatsky, Russia

\section{Torkild Bakken}

NTNU University Museum, Norwegian University of Science and Technology, NO-7491

Trondheim, Norway

\section{Kennet Lundin}

Gothenburg Natural History Museum, P.O. Box 7283, 40235 Gothenburg, Sweden

Gothenburg Global Biodiversity Centre, P.O. Box 461, 40530 Gothenburg, Sweden

\section{Karin Fletcher}

Milltech Marine Port Orchard, Washington, 98366, USA

\section{Alexander V. Martynov}

Zoological Museum, Moscow State University, Bolshaya Nikitskaya Str. 6, 125009 Moscow, Russia

martynov@zmmu.msu.ru

\footnotetext{
Abstract

Cuthonella Bergh, 1884 is of one of the most neglected nudibranch groups, with a long history of taxonomic confusion with other aeolidacean genera. Owing to its predominantly Arctic distribution with 
cold water, its species are difficult to find and to collect, and thus to describe. In this study we revise the genus by presenting molecular and morphological data for a majority of the species, including the type, C. abyssicola Bergh, 1884 . The material is based on a broad geographic sampling throughout the Northern Hemisphere. Particular emphasis is placed on the Kuril Islands, a diversity hotspot for the genus. Seven new species and two subspecies of Cuthonella are described from the Arctic and North Pacific regions. The number of species of Cuthonella is thus increased over threefold and now comprises 15 species plus two subspecies instead of five species. This work is the most substantial update of the genus Cuthonella since its description in 1884. To delineate taxonomic and phylogenetic limits of Cuthonella-like aeolidaceans, the molecular phylogeny of the wider traditional "tergipedids" is presented and shows that Cuthonellalike aeolidaceans form a distinct molecular clade as the family Cuthonellidae Miller, 1977, corroborated by reliable morphological apomorphies.

\section{Keywords}

molecular systematics - morphology - Mollusca - phylogenetics - taxonomic revision

Zoobank: http://urn:lsid:zoobank.org:pub:B52211DD-FA1B-419D-87B7-89EEA19o9266

\section{Introduction}

Nudibranch molluscs are marine invertebrates that display unique adaptations, like the storage of stinging nematocysts from cnidarian prey in their specialized dorsal outgrowths, i.e., cerata, for defence (Martin et al., 2009). Cold waters are commonly equated with low species richness and diversity, whereas tropical waters are usually noted as biodiversity hotspots for marine animals (e.g., Roberts et al., 2002; Hoeksema, 2007; Barman et al., 2018). It has been concluded that a rise in sea water temperature along a latitudinal gradient from the poles to the equator considerably increases biodiversity (e.g., Bickford et al., 2007). This is generally true for nudibranchs as there are many times the number of species in tropical waters compared to the number of species found in cold polar and temperate waters (e.g., Marshall \& Willan, 1999; Martynov \& Korshunova, 2012; Papu et al., 2020). However, for some groups of invertebrates biodiversity is higher in northern seas, e.g. in marine isopods (Poore \& Bruce, 2012) or nudibranchs of the family Dendronotidae (Korshunova et al., 2020a). Here we report the unexpectedly high diversity of a genus of aeolidacean nudibranch molluscs in the waters of the North Pacific.

In this study, we report the discovery of five new species of nudibranch molluscs of the genus Cuthonella Bergh, 1884 among the fauna of a tiny volcanic island, which forms part of the Kuril Islands group. These new species are confirmed with both morphological and molecular data. In addition, we have discovered four more new species and subspecies of the genus Cuthonella from adjacent waters of both sides of the North Pacific and the Arctic. To place these new species within a broad phylogenetic and taxonomic framework of 'tergipedid' aeolidaceans, we reviewed the genus Cuthonella using various specimens collected in the cold waters of the Northern Hemisphere. We also document that the genus Cuthonella, which was originally described from the deep waters of the 
North Atlantic, actually has a wide distribution in the shallow waters of northern Eurasia and northern America. Additionally, based on the broad selection of various aeolidacean taxa, the validity of the family-rank taxon Cuthonellidae Miller, 1977 is confirmed following recent morphological and molecular studies (Korshunova et al., 2017a, 2018a; Martynov et al., 2020a).

\section{Material and methods}

\section{Material examined}

Material for this study was obtained from various expeditions, and includes specimens belonging to different taxa of aeolidacean nudibranchs. These specimens are deposited in the Zoological Museum of Lomonosov MoscowState University(zMMU), Gothenburg Natural History Museum (GNM), Natural History Museum, University of Oslo (zMO), and the NTNU University Museum, Norwegian University of Science and Technology (NTNUVM) (Bakken et al., 2020). The majority of specimens were collected in various locations in the North Atlantic, including Sweden, Norway, the United Kingdom, in the Arctic Sea (including the Barents Sea), the Russian arctic coasts of the White Sea, the East Siberian Sea, the Chukchi Sea, the North Pacific (including Kamchatka, the Kuril Islands, the Sea of Japan, and the Canadian and the United States Pacific coasts). Some specimens were collected during ship-based research cruises in the North Atlantic and the Arctic Seas.

\section{Morphological analysis}

Nudibranch morphology was studied under a stereomicroscope and using digital Nikon D810 and Nikon D6oo cameras. For the descriptions of the internal features, both preserved and fresh specimens (when available) were dissected under a stereomicroscope. The buccal mass of each specimen was extracted and processed in 10\% sodium hypochlorite solution. The features of the jaws of each species were studied under a stereomicroscope and scanning electron microscope (CamScan, JSM). The platinumpalladium coated radulae were examined and photographed using a scanning electron microscope. The reproductive systems were examined and drawn using a stereomicroscope.

\section{Molecular analysis}

Twenty-four specimens of the genus Cuthonella were sequenced for the mitochondrial genes cytochrome c oxidase subunit I (COI) and $16 \mathrm{~S}$ rRNA, and the nuclear genes Histone $3\left(\mathrm{H}_{3}\right)$ and $28 \mathrm{~S}$ rRNA (C1-C2 domain). Small pieces of tissue were used for DNA extraction with Syntol S-Sorb kit by Syntol Company, according to the manufacturer's protocols. The primers and polymerase chain reaction programs that we used are presented in Appendix (table A1). DNA sequences of both strands were obtained using the ABI PRISMiBig-Dye Terminator v.3.1. on an automated DNA sequencer (Applied Biosystems Prism 370O). COI and $\mathrm{H}_{3}$ sequences were translated into amino acids to verify coding regions and avoid improper basecalling. All new sequences were deposited in GenBank (Appendix, table A2; highlighted in bold). Additional molecular data for Cuthonella specimens and several outgroup specimens were obtained from GenBank. All new and publicly available sequences were checked via BLAST searches in GenBank (https://blast.ncbi. nlm.nih.gov/Blast.cgi) to verify identification and avoid potential contamination and errors. Original data and publicly available sequences were aligned with the MAFFT algorithm (Katoh et al., 2002). Separate analyses were conducted for COI (657 bp), 16S (445 bp), H3 (327 bp), 28S (333 bp) and four concatenated markers (1762 bp). The GTR $+\mathrm{I}+\mathrm{G}$ model was chosen for the concatenated datasets using MrModelTest 2.3 (Nylander et al., 2004). Two 
different phylogenetic methods, Bayesian Inference (BI) and Maximum Likelihood (ML), were used to infer evolutionary relationships. Bayesian estimation of posterior probability was performed in MrBayes 3.2 (Ronquist et al., 2012). Four Markov chains were sampled at intervals of 500 generations. Analysis was started with random starting trees and $10^{7}$ generations. ML analysis was performed using RAxML 7.2.8 (Stamatakis et al., 2008) with 1000 bootstrap replicates. Final phylogenetic tree images were rendered in FigTree 1.4.2. Nodes in the phylogenetic trees with Bayesian posterior values > $0.96 \%$ and bootstrap values > 90\% were considered 'highly' supported, nodes with 0.90-0.95\% and 80-89\% accordingly were considered 'moderately' supported (lower support values were considered not significant, Korshunova et al., 2018a). The program MEGA7 (Kumar et al., 2016) was used to calculate the uncorrected p-distances between all the sequences. Automatic Barcode Gap Discovery (ABGD) (Puillandre et al., 2012) was used to estimate the diversity of Cuthonella species. An alignment of the COI marker was submitted and processed in ABGD using the JukesCantor (JC69) and Kimura (K8o) models and the default settings. To evaluate the genetic distribution of the different haplotypes, a haplotype network for the cor molecular data was reconstructed using Population Analysis with Reticulate Trees (PopART, http://popart. otago.ac.nz) with the TCS network method.

\section{Results}

\section{Molecular analysis}

In this molecular study, 55 specimens of Cuthonella were included, combining 78 novel sequences with 93 sequences from GenBank. Six outgroup specimens (22 sequences) from the genera Murmania, Xenocratena, and Calma were used according to previous results (Korshunova et al., 2017b, 2018a; Martynov et al., 2019, 202Oa). Bayesian Inference (BI) and Maximum Likelihood (ML) analyses based on the combined dataset for the mitochondrial COI and $16 \mathrm{~S}$, and the nuclear $\mathrm{H}_{3}$ and $28 \mathrm{~S}$ genes yielded similar results (figs 1, 2).

All Cuthonella species constituted a highly supported clade ( $\mathrm{PP}=1, \mathrm{BS}=99)$. The ABGD analysis of the COI dataset run with two different models revealed 14 lineages that could be assigned to morphologically distinct Cuthonella species (fig. 1): Cuthonella osyoro (Baba, 1940), C. soboli Martynov, 1992, C. georgstelleri sp. nov., C. benedykti sp. nov., C. ainu sp. nov., C. hiemalis (Roginskaya, 1987), C. denbei sp. nov., $C$. vasentsovichi sp. nov., $C$. concinna (Alder \& Hancock, 1843) with subspecies $C$. concinna bellatula subsp. nov. and $C$. concinna concinna, C. sandrae sp. nov., C. abyssicola kryos subsp. nov., C. punicea (Millen, 1986), and two potential species in the $C$. cocoachroma (Williams \& Gosliner, 1979) group. Cuthonella soboli was sister $(\mathrm{PP}=1, \mathrm{BS}=100)$ to $C$. osyoro; C. benedykti sp. nov. $(\mathrm{PP}=1, \mathrm{BS}=97)$ was sister $(\mathrm{PP}=1, \mathrm{BS}=100)$ to $C$. ainu sp. nov. and together with $C$. georgstelleri sp. nov. they formed a highly supported lineage ( $\mathrm{PP}=1, \mathrm{BS}=98)$. Cuthonella sandrae sp. nov. and $C$. abyssicola kryos subsp. nov. clustered in two distinct and separate sister clades $(\mathrm{PP}=0.98, \mathrm{BS}=92)$ that formed the sister group $(\mathrm{PP}=1, \mathrm{BS}=98)$ to the maximally supported $(\mathrm{PP}=1, \mathrm{BS}=100)$ C. punicea clade. Unresolved evolutionary ties were revealed for the $C$. concinna clade. All seven $C$. concinna specimens from the NE Pacific formed a separate clade $(\mathrm{PP}=0.99, \mathrm{BS}=90)$ and clustered together with sixteen $C$. concinna individuals from the NE Atlantic $(\mathrm{PP}=1, \mathrm{BS}=100)$.

The maximum intragroup distance for the COI marker in C. concinna from the NE Atlantic is $0.91 \%$ and in C. concinna from the NE Pacific the maximum intragroup distance is $1.67 \%$. The minimum intergroup distance for the COI marker between the NE Atlantic and the NE Pacific C. concinna is $1.07 \%$. Thus, the molecular divergence within $C$. concinna from the NE Downloaded from Brill. com๑4/26/2023 12:21:06PM 


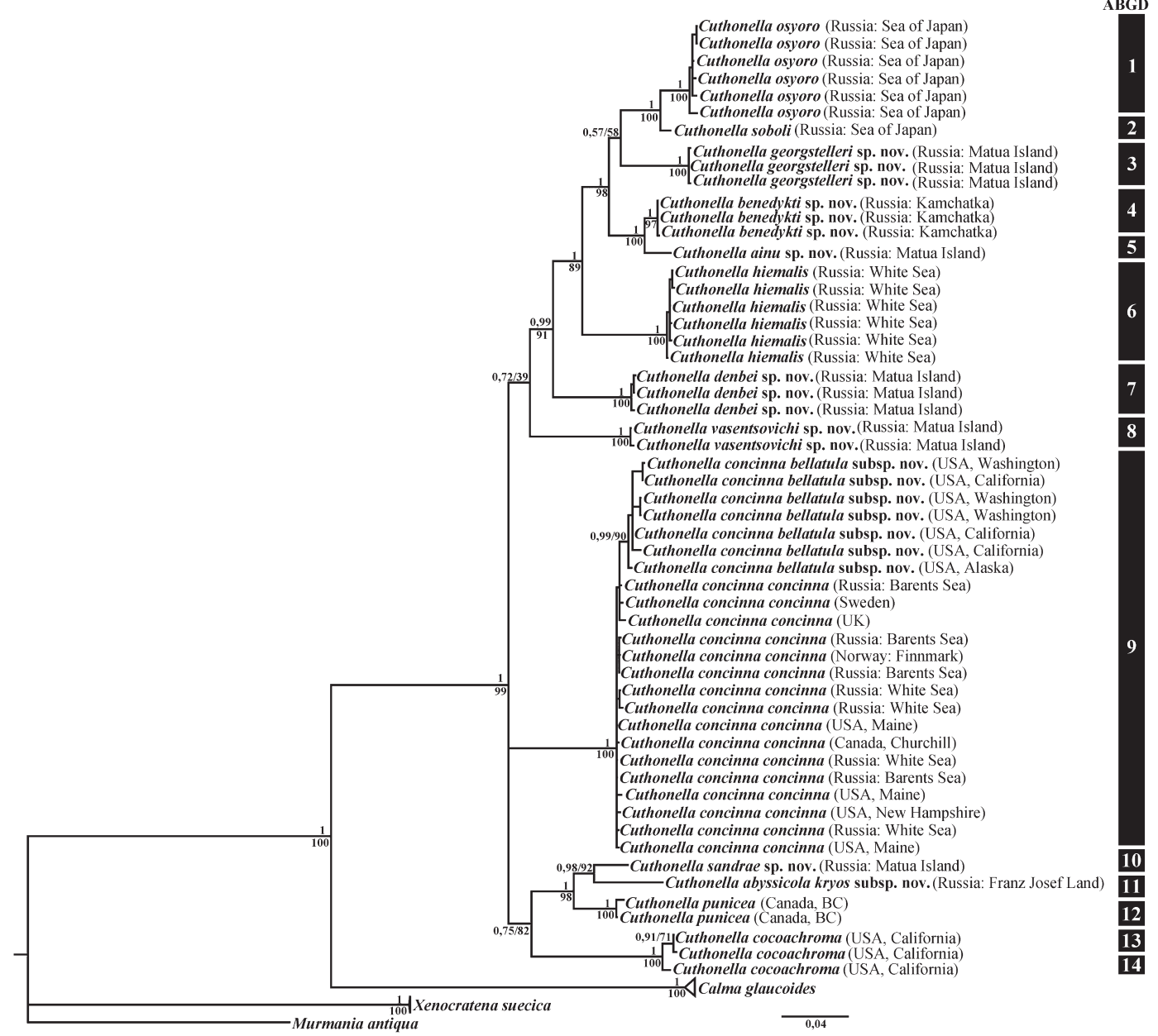

FIGURE 1 Phylogenetic relationships of Cuthonella based on COI $+16 \mathrm{~S}+\mathrm{H}_{3}+28 \mathrm{~S}$ concatenated dataset inferred by Bayesian inference (BI). Numbers above branches represent posterior probabilities from BI; numbers below branches indicate bootstrap values for Maximum Likelihood. Summary of species delimitation results are noted by numbered clusters from the abgd analyses for the co I dataset.

Pacific group exceeded the molecular divergence between the NE Atlantic and the NE Pacific. The division of $C$. concinna into two subgroups (C. concinna concinna and $C$. concinna bellatula subsp. nov.) was also confirmed by the haplotype network based on coI molecular data (fig. 3). Two C. cocoachroma (CAS179471 and CAS185193) clustered together $(\mathrm{PP}=0.91, \mathrm{BS}=71)$ and formed the sister group to the $C$. cocoachroma CAS181307b. All three $C$. cocoachroma formed a maximally supported clade $(\mathrm{PP}=1, \mathrm{BS}=100)$. The COI distance of $0.15 \%$ is found between $C$. cocoachroma CAS179471 and C. cocoachroma
CAS185193. The col distances of $1.37 \%$ and $1.5^{2} \%$ are found between $C$. cocoachroma CAS181307b and two C. cocoachroma (CAS179471 and $\mathrm{CAS} 185193$ ) respectively. The ABGD analysis suggested that two potential species within $C$. cocoachroma may become revealed in future studies. Nevertheless, the three $C$. cocoachroma specimens aligned as the same species in the present analysis according to the integrative molecular results. The maximum intragroup and minimum intergroup genetic distances in Cuthonella species for the COI marker are presented in table 1 . 


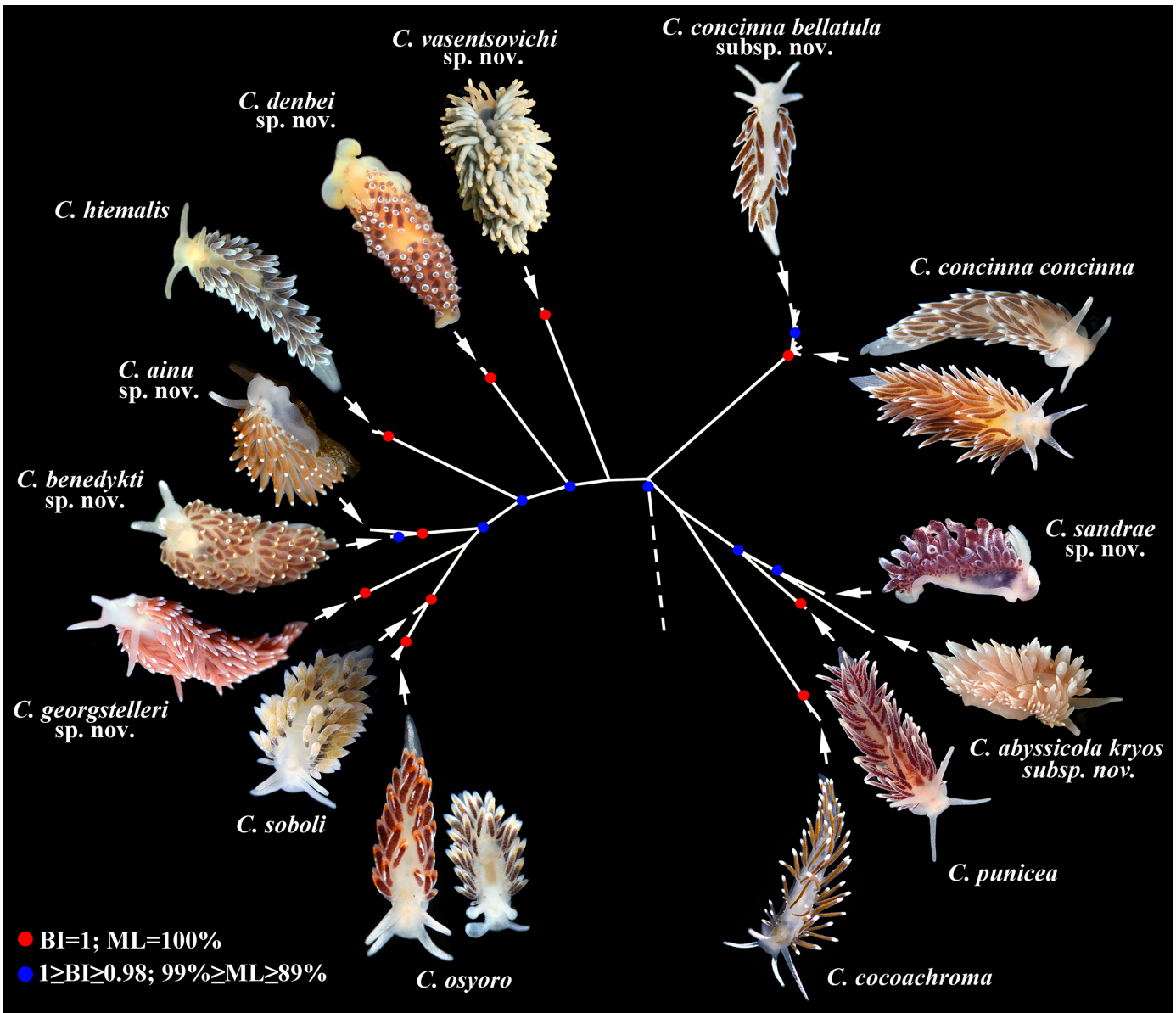

FIGURE 2 Phylogenetic relationships of Cuthonella based on COI $+16 \mathrm{~S}+\mathrm{H}_{3}+28 \mathrm{~S}$ concatenated dataset inferred by Bayesian inference (BI), radial tree layout. Posterior probabilities from BI and bootstrap values for Maximum Likelihood (ML) are indicated on the figure. Cuthonella species are illustrated on the tree.

\section{Cuthonella concinna concinna}

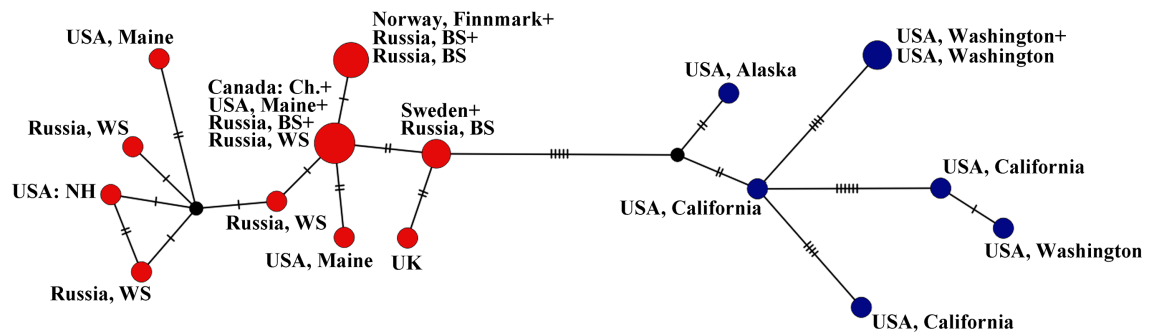

FIGURE 3 Haplotype network based on cytochrome c oxidase subunit I (COI) molecular data showing genetic mutations occurring within Cuthonella concinna concinna (red circles) and Cuthonella concinna bellatula subsp. nov. (blue circles) species. Abbreviations: BS: Barents Sea; Ch: Churchill (Canada); NH: New Hampshire; UK: United Kingdom; WS: White Sea. 


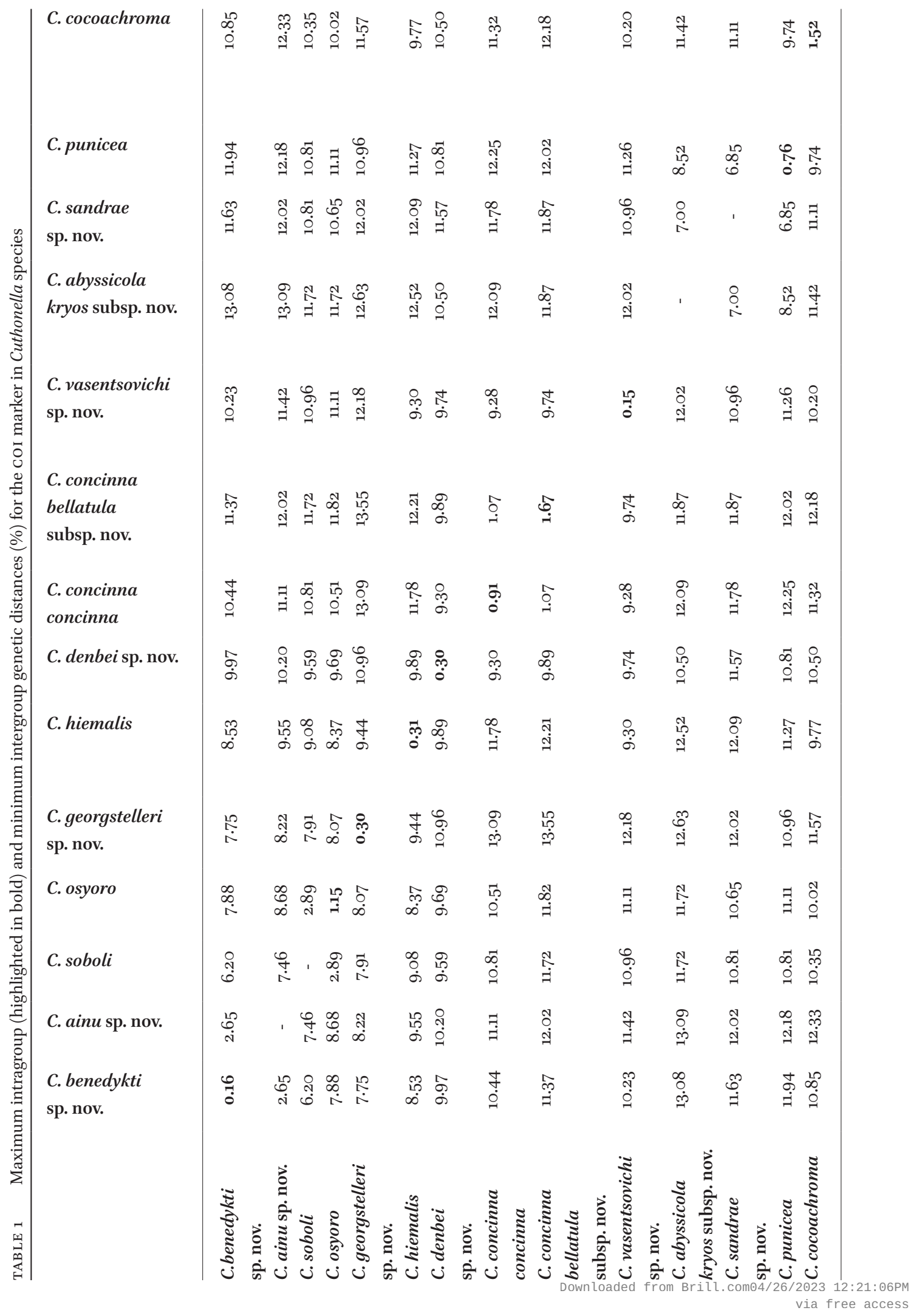




\section{Systematic account}

Family Cuthonellidae Miller, 1977

Diagnosis. Aeolidaceans with a wide to moderately broad body. Notal edges fully reduced. Cerata non elevated, several per row. Ceratal rows branched or simple. Rhinophores smooth to wrinkled, without distinct lamellae. Anus acleioproctic or cleioproctic, in anterior to middle part of dorsal side. Radula formula o.1.o. Rachidian teeth usually with strong cusp, not compressed by adjacent lateral denticles. Distal receptaculum seminis present. Vas deferens usually moderate, with indistinct prostate. Massive external permanent penial collar absent. Penis internal, unarmed. Supplementary gland present, commonly inserts to vas deferens.

Type genus Cuthonella Bergh, 1884.

\section{Genus Cuthonella Bergh, 1884}

(Figs 1-22)

Cuthonella Bergh, 1884: 23-24.

Cuthonella Martynov, 1992, revision: 23.

Non Cuthona sensu Millen (1986)

Type species: Cuthonella abyssicola Bergh, 1884. Recent, North Atlantic Ocean. Gender feminine.

Diagnosis. Body wide to moderately broad (rarely more narrow). Cerata numerous, continuous. Rhinophores smooth to wrinkled, longer or similar in size to oral tentacles. Anterior foot corners never tentaculate. Anus acleioproctic (rarely cleioproctic). Central teeth with strong cusp and distinct denticles. Distal receptaculum seminis. Long vas deferens without separate granulated prostate. Supplementary gland (= "penial gland") inserts into vas deferens. Penis commonly elongated conical, unarmed.

Contained species: Cuthonella abyssicola abyssicola Bergh, 1884 (fig. 4), C. abyssicola kryos subsp. nov. (fig. 5), C. ainu sp. nov. (fig. 6), C. benedykti sp nov. (fig. 7), C. cocoachroma (Williams \& Gosliner, 1979), C. concinna concinna (Alder \& Hancock, 1843) (fig. 8), C. concinna bellatula subsp. nov. (fig. 9), C. denbei sp. nov. (fig. 10), C. elenae Martynov, 200o, C. georgstelleri sp. nov. (fig. 11), C. hiemalis (Roginskaya, 1987) (fig. 12), C. orientosiberica sp. nov. (fig. 13), C. osyoro (Baba, 1940) (fig. 14), C. punicea (Millen, 1986) (fig. 15), C. sandrae sp. nov. (fig. 16), C. soboli Martynov, 1992 (fig. 17), C. vasentsovichi sp. nov. (fig. 18).

Remarks. Until 1992, the genus Cuthonella was rarely used to refer just to the deep-sea species, C. abyssicola, and its two synonymous taxa (e.g., Odhner in Franc, 1968; Miller, 1977), or more often it was considered invalid (Millen, 1986). Other species that demonstrate morphological similarities to the type species $C$. abyssicola were never considered as belonging to the genus Cuthonella in faunal lists and guides (e.g., Odhner, 1907, 1939; Thompson \& Brown, 1984; Behrens, 1980; Behrens \& Hermosillo, 2005). Martynov (1992) initially revised the composition of the genus Cuthonella to include six species $-C$. abyssicola (Bergh, 1884), C. concinna (Alder \& Hancock, 1843), C. distans (Odhner, 1922), C. hiemalis (Roginskaya, 1987), C. marisalbi (Roginskaya, 1963), C. punicea (Millen, 1986) and to describe a new one, C. soboli Martynov, 1992.

Thus, a future monophyletic molecular clade (fig. 1) was predicted using only morphological data. This is a clear indication that morphological data (ontogenetic in a broad sense) should have value independent of molecular data (Korshunova et al., 2017a, b) instead of being considered merely an inferior auxiliary addition, a view commonly held in the current use of molecular techniques to delineate species (e.g., Carmona et al., 2013).

In the present study, five of the seven species that were included in the genus Cuthonella by Martynov (1992) are confirmed to belong to the monophyletic molecular clade that includes Cuthonella abyssicola s.l. Moreover, Cuthonella concinna s.l., C. hiemalis (Roginskaya, 1987), C. punicea (Millen, 1986) 
and $C$. soboli Martynov, 1992 are confirmed to be valid species (figs 1-3, 4, 8, 12, 15, 17), whereas $C$. distans (Odhner, 1922) and $C$. marisalbi (Roginskaya, 1963) - while still Cuthonella as predicted by Martynov (1992) are now both considered to be junior synonyms of Cuthonella concinna concinna (see below and fig. 8).

Previously, a few Antarctic species were described under the genus Cuthonella, i.e. Cuthonella antarctica Eliot, 1907 (currently is known under a replacement name Cuthonella elioti (Odhner, 1944)), Cuthonella modesta Eliot, 1907 and Cuthonella paradoxa Eliot, 1907. Since $C$. elioti is known to have supplementary gland that inserts into the penial base and possibly a penial stylet, and $C$. modesta is also described as having supplementary gland that inserts into the penial base and jaws without denticles (Eliot, 1907; Valdés et al., 2012), they are definitely not considered to be Cuthonella. The taxonomic placement of these taxa should be addressed in a separate study.

It has also subsequently been shown that Cuthonella paradoxa belongs to a valid Antarctic genus Guyvalvoria Vayssière, 1906, and has been synonymised with the type species of the genus Guyvalvoria, $G$. francaisi Vayssière, 1906 because of the high morphological similarity (Martynov, 2006a). However, Guyvalvoria paradoxa sensu Valdés et al. (2012: 1171-1173) does not match the original description of Cuthonella paradoxa in Eliot (1907: 24-25) and considerably differs in the radular morphology. There are seven distinct, "fairly stout and long" lateral denticles of the central teeth in the original description of Cuthonella paradoxa (Eliot 1907: 25, $11 \mathrm{~mm}$ preserved length) and 13-15 small denticles in Guyvalvoria "paradoxa" sensu Valdés et al. (2012: 1172, $15 \mathrm{~mm}$ preserved length). Notably, a fewer number (ca. $5^{-11}$ ) of distinct, long lateral denticles is well attested for the type species of Guyvalvoria, G. francaisi Vayssière, 1906 with similar body size (up to $14.5 \mathrm{~mm}$ preserved length), whereas another Antarctic species Guyvalvoria gruzovi Martynov, 2006 has a clearly larger number (11-15) of less distinct lateral denticles in specimens with smaller $(8-9 \mathrm{~mm})$ preserved body length (Martynov, 2006a: 78-84). In addition, Cuthona schraderi (Pfeffer in Martens \& Pfeffer, 1886) was considered as a potential synonym of $G$. "paradoxa" sensu Valdés et al. (2012: 1173). Nonetheless, Cuthona schraderi differs significantly from any species of the genus Guyvalvoria by the presence of distinct ceratal rows and from G. "paradoxa" sensu Valdés et al. (2012) also by considerably fewer lateral denticles (Odhner, 1926). Thus, Cuthona schraderi is not a potential synonym of $G$. francaisi Vayssière, 1906 or G. "paradoxa" sensu Valdés et al. (2012: 1173). According to the morphology of the radular teeth and reproductive system, Guyvalvoria "paradoxa" sensu Valdés et al. (2012) is the most similar to G. gruzovi (Martynov, 2006a), but not to $G$. francaisi Vayssière, 1906 (= "Cuthonella" paradoxa Eliot, 1907).

The genus Guyvalvoria is a well-defined taxon by the very specific combination of a posterior anus, laterally compressed branched rows of cerata, uniserial radula and a supplementary gland that inserts into the penial base. These features were already described in detail elsewhere (Martynov, 2006a) and by those characters Guyvalvoria is not only clearly different from the genus Cuthonella, but also from the majority of other aeolidacean families (Korshunova et al, 2017b; Martynov et al., 2020a). Some morphological similarity in presence of the posterior anus Guyvalvoria shares only with the family Murmaniidae (Martynov, 2006a; Martynov et al., 2020a). Therefore, Guyvalvoria recently was transferred with 
reservation to the family Murmaniidae (Korshunova et al., 2017b: Supplementary material1, Synopsis of the families of suborder Aeolidacea). The current status of the genus Guyvalvoria as "taxon inquirendum" of the "family Eubranchidae" (MolluscaBase, 2020) should therefore be corrected to fully valid status and, pending the availability of molecular data, to the family Murmaniidae. The family Murmaniidae, on one hand, is morphologically consistent with the characters of Guyvalvoria, but on the other hand, is related to the families Cuthonellidae and Xenocratenidae according to the most recent phylogenetic analysis (Martynov et al., 2020a). Therefore a future phylogenetic analysis will show if Guyvalvoria can be retained in the family Murmaniidae or should be placed in its own family.

In the original diagnosis of the genus Cuthonella, Bergh (1884) did not mention the key feature that has proven to be present in all species of the genus Cuthonella studied so far (except for uncertainties in the species $C$. cocoachroma Williams \& Gosliner, 1979, see below), which is that the supplementary gland is inserted into the vas deferens instead of the penis (Martynov, 1992; present study). From the characters initially mentioned by Bergh (1884), the dorso-lateral position of the anus cannot be considered specific for the genus Cuthonella, and the absence of cnidosacs in the type species of the genus Cuthonella was disproved by Millen (1986).

So, at this time the genus Cuthonella should be defined by the following features: relatively abundant anterior pre-anal rows of cerata, either branched or unbranched (the majority of species have at least five to six, or more, pre-anal ceratal rows in the adult state), a predominantly acleioproctic anus (the type species and a few other species may have a cleioproctic one), relatively broad jaws with usually a single row of distinct denticles (the type species apparently may also have a few additional indistinct rows), an exclusively uniserial radula with a central cusp always protruding (except for the few anteriormost eroded teeth), either with lateral denticles closely adhering to the central cusp (as in the type species) or usually distinct from the central cusp. In the reproductive system, so far only a single receptaculum seminis is reported (with a tendency to be more proximal in Cuthonella concinna s.l., otherwise in the majority of species it is distal) and the receptaculum seminis is usually oval, but it can also be a rather tubular one (e.g., C. abyssicola s.l., C. punicea). The penis is unarmed.

The most specific feature of the genus - the insertion of the supplementary gland into the vas deferens instead of the penis - was evident in all the Cuthonella species that we were able to examine (figs 4-20). Cuthona norvegica was originally described by Odhner (1929) within the genus "Cuthonella". However, $C$. norvegica has a supplementary gland inserted into the penial base (Millen, 1986) and was transferred to the genus Cuthona s.str. by Martynov (1992). There are no new specimens of Cuthona norvegica available, and after a future clarification of its phylogenetic position, it may be necessary to transfer this species to a different genus.

The insertion of the supplementary gland into the vas deferens is likely a plesiomorphic feature because it is also present in at least one very different taxon with a triserial radula - Eubranchus tricolor - within the family Eubranchidae (Korshunova et al., 2017a, b). Potentially, this feature may occur within some other basal 'tergipedids'. However, among genera and families with a uniserial radula it has so far been confirmed only for Cuthonella and Cuthonellidae. Therefore, the insertion of the supplementary gland into the vas deferens should be used in combination with the other characters mentioned above to identify future 
members of Cuthonellidae. Notably, within the family Cuthonidae (genera Cuthona and Bohuslania) this feature has so far never been observed (Korshunova et al., 2017a, 2018a).

The family Cuthonellidae Miller, 1977 has been resurrected recently, including a morphological diagnosis and molecular phylogenetic data (Korshunova et al., 2017a, b, 2018a). Miller (1977: 200) proposed the subfamily name Cuthonellinae based on the valid genus name Cuthonella and provided a brief morphological diagnosis "digestive ducts unbranched". This diagnosis meets the requirements of the relevant ICZN (1999) articles (i.e., 11.7, 13, 29) for the availability of a family group name. Miller (1977: 200) also mentioned that the name Cuthonellinae "replaced" the name Precuthoninae introduced by Odhner in Franc (1968: 885). Miller did not provide explanations of his reasons and did not make a special indication why this is a "replacement" name. Bouchet \& Rocroi (2005: 59) commented that Cuthonellinae Miller (1977) was invalid; they said in their remarks that it was "Introduced presumably (and thus in violation of Art. 40.1)
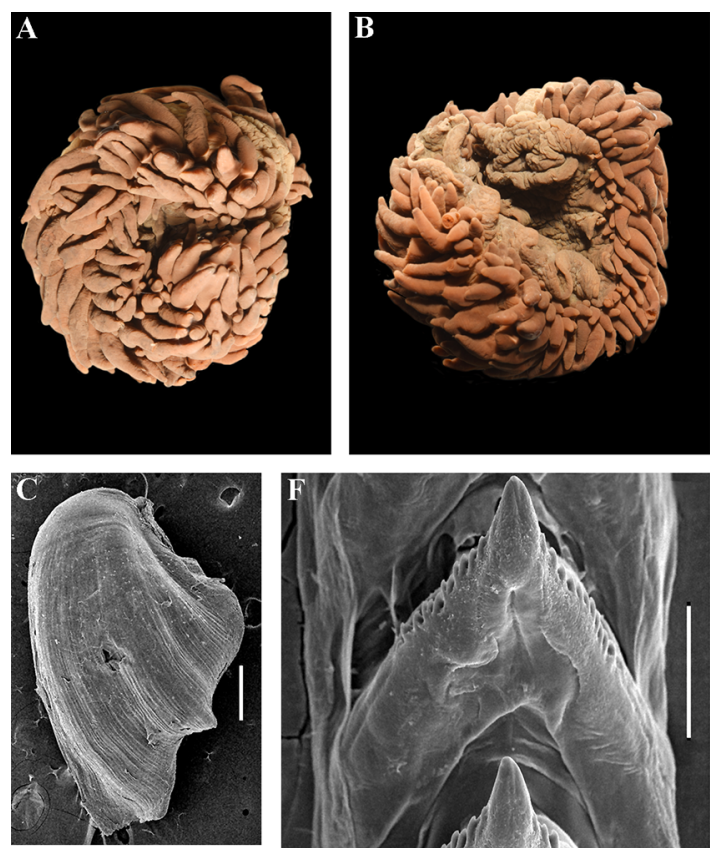

D
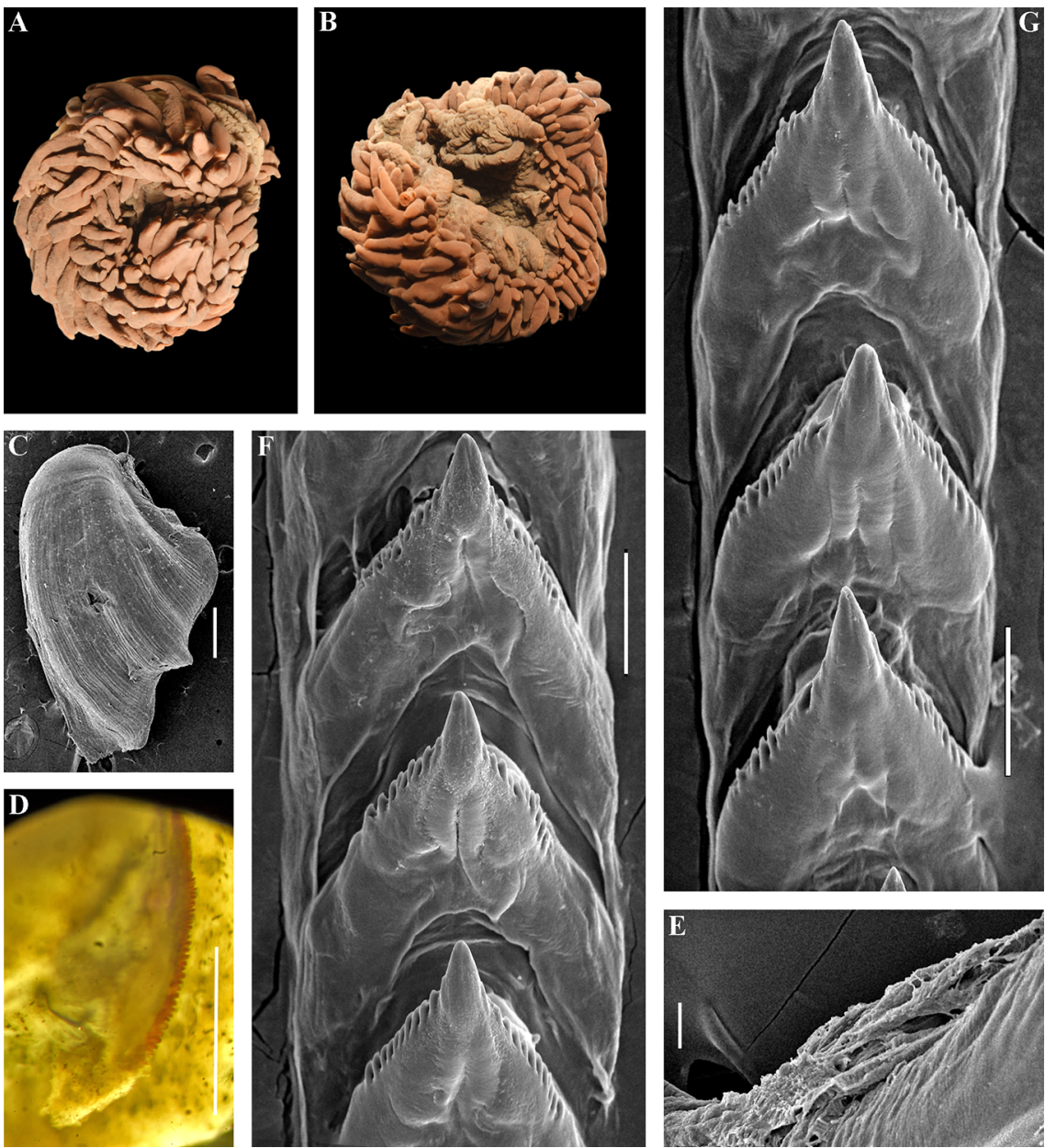

FIGURE 4 Cuthonella abyssicola abyssicola Bergh, 1884. A, B, dorsal and ventral views, respectively, of a preserved specimen ZMMU Op-616 from the deep waters of the Barents Sea, 23 mm. C, jaw (SEM). D, jaw, details (light microscopy). E, jaws, details (SEM). F, posterior part of the radula (SEM). G, anterior part of the radula (SEM). Scale bars: C, D, $500 \mu \mathrm{m}$; E, $10 \mu \mathrm{m} ; \mathrm{F}, \mathrm{G}, 30 \mu \mathrm{m}$; Photos: Alexander Martynov. 
as a replacement name for Precuthoninae, because Cuthonella has precedence over Precuthona Odhner, 1929." However, Precuthona Odhner, 1929 is not a synonym of the genus Cuthonella Bergh, 1884 and therefore there is no violation of Article 40.1 of ICZN (1999). The name Precuthona Odhner, 1929 is a synonym of the genus Cuthona (Brown, 1980), which belongs to the different family Cuthonidae, supported by morphological and molecular data (Korshunova et al., 2017a, 2018a). The name Precuthoninae Odhner in Franc (1968: 885), therefore, is a synonym of the family Cuthonidae Odhner, 1934. The name Cuthonellinae Miller, 1977 is thus an available family group name in full compliance with Article 13 ("to be available, every new family-group name published after 1930 must satisfy the provisions of Article 13.1 and must be formed from an available genus-group name then used as valid by the author in the family-group taxon [Arts. 11.7.1.1, 29]", ICZN 1999). The available family group name Cuthonellinae Miller, 1977 (in a restricted sense compared to the mention in Miller (1977), without "Precuthona") with an amended diagnosis was therefore introduced as the valid family Cuthonellidae Miller, 1977 and the (incorrect and unnecessary) term "replaced" should be discounted.

Cuthonellidae is distinct by the morphological and molecular phylogenetic data (Korshunova et al., 2017a, 2018a, this study). In some publications (Korshunova et al., 2017a, b) the year of the original publication of Cuthonellinae was indicated as 'Miller, 1971' due to a typo (the reference 'Miller, 1977' was provided correctly). The correct year of publication is Miller (1977). The type genus of the family Cuthonellidae is Cuthonella Bergh, 1884.

In the present revision of the genus Cuthonella the number of known species is increased threefold. It is the most substantial update to the knowledge of the genus Cuthonella since its description in 1884. All previously known and novel species are presented below in alphabetical order (figs $4^{-18) .}$

Cuthonella abyssicola abyssicola Bergh, 1884

(figs 1, 2, 4, 19A, 21)

Cuthonella abyssicola Bergh, 1884: 24-26, pl. 10, figs. 1-3, pl. 11, fig. 2, pl. 12, figs. 913; Martynov, 1992: 23; Martynov, 2006a: 73; Martynov, 2006b: 29o; Martynov \& Korshunova, 2011: 195.

Cuthonella berghi Friele, 1903: 11, tab. II, fig. 3-4, tab. III, fig. 7-10.

Cuthonella ferruginea Friele, 1903: 10, tab. II, fig. $1-2$, tab. III, fig. $3-5$.

Cuthona abyssicola (Bergh, 1884) - Millen, 1986: 1358-1359, figs 8, 9.

Type material. Holotype lost (K. Jensen (ZMUC), personal communication; K. Lundin performed an additional search in ZMUC and confirmed the absence of the type material).

Material. ZMMU Op-616, $L=23 \mathrm{~mm}$ length (preserved, convoluted, more than $30 \mathrm{~mm}$ if unrolled), Arctic Ocean, Barents Sea, $77^{\circ} \circ 6^{\prime} \mathrm{N}, 5^{\circ} 12^{\prime} \mathrm{E}, 307 \mathrm{~m}, 07.08 .1948$. NTNU-VM 73124, 1 spec., $\mathrm{L}=31 \mathrm{~mm}$ length (preserved), Norwegian Sea, Nyegga, $64^{\circ}$ $40.115 \mathrm{~N} 5^{\circ}$ 15.702E, $731 \mathrm{~m}$, coll. Hans Tore Rapp, 05.08.2008.

External morphology. Body wide, massive. Foot and tail broad. Oral tentacles moderate. Rhinophores smooth to slightly wrinkled, similar in size to oral tentacles. Dorsal cerata elongate, thick, arranged in continuous rows. Up to 17 pre-anal branched ceratal rows. Anal opening cleioproctic.

Colour (preserved). Background colour yellowish white. Digestive gland diverticula in cerata possibly reddish to pinkish. Ceratal tips without distinct spots or bands of opaque white pigment. 
Jaws. Jaws broad, yellowish to brown in colour. Masticatory processes of jaws covered with several rows of denticles (with a few indistinct additional rows) (fig. 4C-E).

Radula. Radula formula $21 \times 0.1 .0$ (specimen $23 \mathrm{~mm}$ in length, Barents Sea). Central tooth broad, with a strongly protracted, pointed non-compressed cusp (fig. 4F, G). Central teeth with up to 14 lateral denticles, which are rarely clustered. Cusp quite clearly delineated from the adjacent lateral denticles which do not reach the top of the cusp.

Reproductive system. Diaulic. Hermaphroditic duct leads to a swollen ampulla. Vas deferens long, without a distinct prostate. Supplementary gland long, inserts into the vas deferens at a considerable distance from the elongated penial sheath. Penis conical, strong, unarmed. Oviduct connects through the insemination duct into the female gland complex. Exceedingly long tubular receptaculum seminis placed distally, widened in the middle part with a small oval reservoir (fig. 19A).

Ecology. Lives on soft bottoms with stones, commonly at bathyal and shelf depths of $c$. 300-1112 m. A record from the shallow waters of the Laptev Sea (Martynov \& Korshunova, 2011) (49 m depth) needs verification.

Distribution. Faroe Islands in the North Atlantic; Norwegian Sea; Barents Sea, possibly the Laptev Sea (Millen, 1986; Martynov \& Korshunova, 2011; present study).

Remarks. Cuthonella abyssicola differs from the majority of other Cuthonella species by the substantial number of anterior ceratal rows (up to 17), radular teeth with small denticles which are not always clearly delineated from the cusp, long vas deferens and distal seminal receptacle on a very long stalk.

In the present study, we give for the first time both morphological and molecular data for a relatively shallow-water specimen from Franz Joseph Land in the Arctic (see description below). Morphologically, this specimen showed closely similar features with the deeper-water specimens (300 m) from the Barents Sea in the presence of up to 17 pre-anal branched ceratal rows, a long vas deferens and a receptaculum seminis on a long stalk. In the original description (Bergh, 1884), a type specimen from deeper waters of the Faroe Channel (c. $1000 \mathrm{~m}$ ) shows closely similar external and reproductive features with the shallowwater specimen from Franz Joseph Land, but the radular teeth have a significantly fewer number of lateral denticles (10-14 vs. 13-36). Notably, in the Franz Joseph Land specimen the lateral denticles are usually clustered and extend to the top of the central cusp (fig. 5I, J), compared to the deep-sea $C$. abyssicola (fig. 4F, G). Millen (1986) performed a detailed investigation of the surviving type material of the nominal species Cuthonella berghi Friele, 1903 and C. ferruginea Friele, 1903, which have been considered synonymous with $C$. abyssicola. Both of these synonymous species come from similar geographic regions (NE Atlantic, Norwegian Sea) and also from similar depths (from deeper waters of 590-1098 m) as C. abyssicola. The radulae of $C$. berghi and $C$. ferruginea are similar to the original description of $C$. abyssicola (Bergh 1884): the central teeth possess only a few lateral denticles (c. 6-10), and the cusp is more clearly delineated. This agrees well with our specimens from the deep waters of the Barents Sea (c. 6-14) (fig. $4 \mathrm{~F}$, $G)$. The number of teeth of the radula of the deeper water specimen from the Barents Sea (21 teeth) also corresponds well with the first description of Bergh (1884) and also to those described by Friele (1903) and Grieg (1913) (18-21 teeth), but not to the shallow-water specimen from Franz Joseph Land (27 teeth). Thus, the radular characters (which are reliably based on several deep-sea specimens collected in various locations) are different 

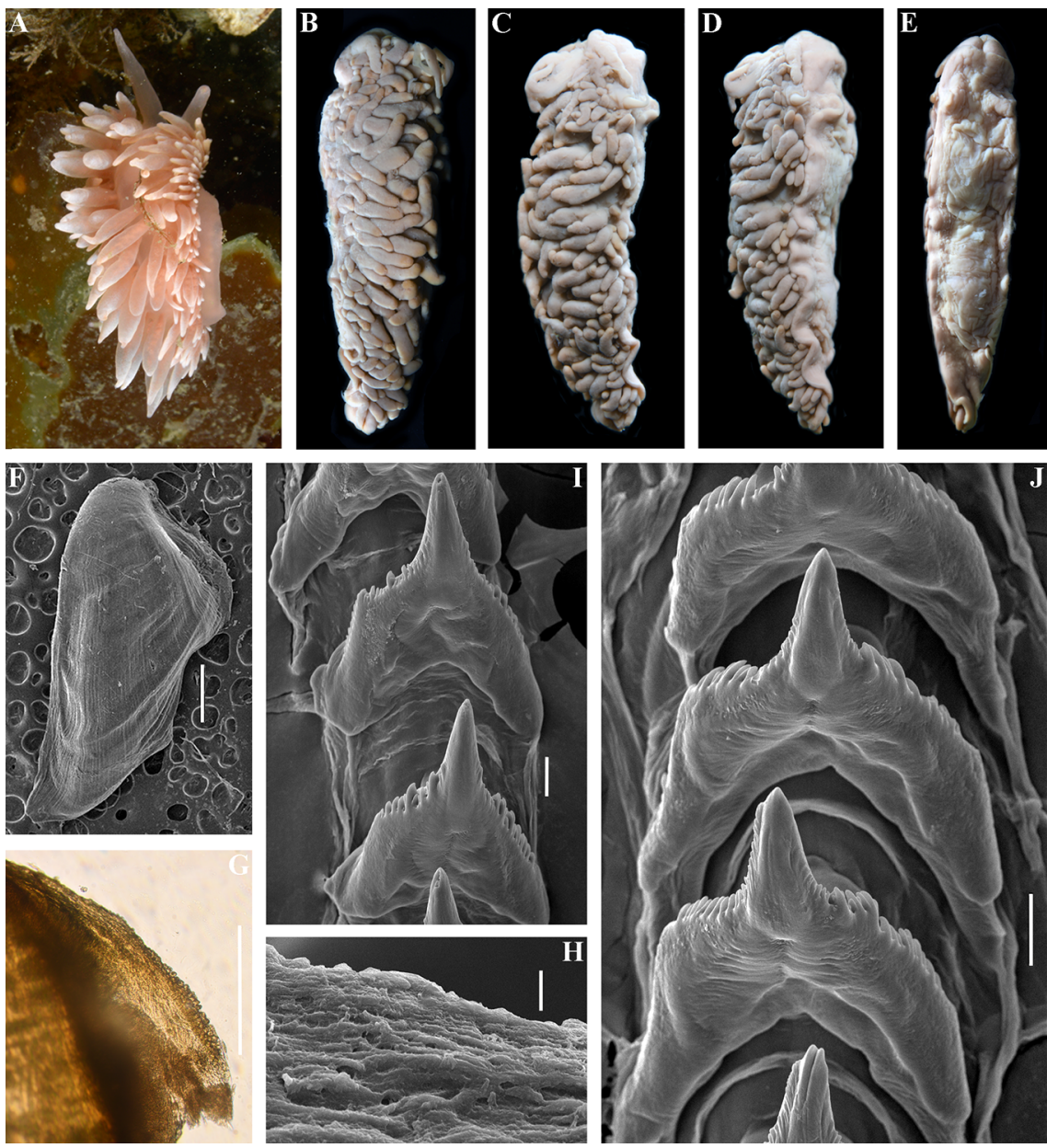

FIGURE 5 Cuthonella abyssicola kryos subsp. nov. A, dorsal view of living holotype ZMmU Op-727, shallow water of Franz Josef Archipelago, $25 \mathrm{~mm}$ (preserved length). B-E, dorsal, lateral, latero-ventral and ventral views respectively of the same preserved specimen. F, jaw (SEM). G, jaw, details (light microscopy). $\mathrm{H}$, jaws, details (SEM). I, anterior part of the radula (SEM). J, posterior part of the radula (SEM). Scale bars: F, G, $500 \mu \mathrm{m}$; H, 50 m; I, J, $100 \mu \mathrm{m}$; Photos: A, Oleg Savinkin, B-J, Alexander Martynov.

from the shallow-water specimen from Franz Joseph Land, which by other features are similar to the real $C$. abyssicola. Therefore, these differences cannot be ignored while making a taxonomic decision. Because only a single shallow-water specimen was available, we preferred in this case to separate it here as a subspecies; Cuthonella abyssicola kryos subsp. nov. (see description below).

It was previously shown (Korshunova et al., 2017b; Martynov \& Korshunova, 2017) that the waters of Franz Josef Land demonstrate considerable endemism in other various nudibranch taxa, such as in the genera Adalaria, Microchlamylla, and Ziminella. We have also studied a single specimen from the Laptev Sea, from a relatively shallow-water locality at $c .5^{\circ} \mathrm{m}$. Remarkably, compared to the specimen from Franz Joseph Land, the Laptev Sea specimen possesses no more than 14-15 lateral denticles on the central tooth (23 teeth in total), and thus more closely matches the real deep-sea $C$. abyssicola than the Franz Joseph Land specimen. Thus, the distributional data for $C$. abyssicola abyssicola and C. abyssicola kryos subsp. nov. 
implies that the nominative subspecies can be found in shallow depths, but not in the high latitude Franz Joseph Land. It should also be taken into consideration that the shallow-water record from the Laptev Sea needs further verification. C. abyssicola s.l. potentially feeds on athecate hydroids. We have studied few deep-sea specimens of C. abyssicola abyssicola, but none of them were suitable for molecular investigation due to the considerable age of collection and primary fixation in formaldehyde. We made additional inquiries to obtain recent deep-sea specimens, but none were available. Therefore, though details of the radular features and distributional patterns may potentially imply that we are dealing with two sister species rather than with two subspecies, we need more data to confirm this. However, because the shallow-water subspecies (see below) shows substantially similar major features in both external and internal morphology, including the reproductive system, we can confirm that it represents a form that is close to the original Cuthonella abyssicola and therefore can be used here for defining the genus Cuthonella. For a morphological comparison with other Cuthonella species, see table 2.

\section{Cuthonella abyssicola kryos subsp. nov.}

(Figs 1, 2, 5, 19B, 21)

ZooBank:

http://urn:lsid:zoobank. org:act: $9 \mathrm{~F}_{7} \mathrm{FA}_{1} \mathrm{E}_{7}-3326$ - 4 o o 9-9F 9 B $\mathrm{ADFFC1OE}_{7} \mathrm{~F}_{2}$

Type material. Holotype, zMMU Op-727, $L=25 \mathrm{~mm}$ length (preserved), Arctic Ocean, Franz Josef Land, Wiltona Island, 18-33 m depth, collected by O.V. Savinkin, 23.08.2013.

Etymology. From Ancient Greek xpúos (kryos), "icy cold" in reference to the Arctic, high latitude type locality.

External morphology. Body wide, massive. Foot and tail broad. Oral tentacles moderate. Rhinophores similar in size to oral tentacles, smooth to slightly wrinkled. Dorsal cerata elongate, thick, arranged in continuous rows. Up to 17 pre-anal branched ceratal rows. Anal opening cleioproctic.

Colour (live). Background colour light pinkish to whitish. Digestive gland diverticula in cerata light pinkish to whitish. Ceratal tips with dispersed white pigment. Rhinophores light yellowish with indistinct white pigment towards the top (fig. $5 \mathrm{~A}$ ).

Jaws. Jaws broad, yellowish to brown in colour. Masticatory processes of jaws covered with a few rows of denticles (with a few indistinct additional rows) (fig. $5 \mathrm{~F}, \mathrm{G}, \mathrm{H}$ ).

Radula. Radula formula $27 \times$ o.1.o. Central tooth broad, with a strongly protracted, pointed non-compressed cusp (fig. 5I, J). Central teeth with up to 36 lateral denticles (often clustered and increasingly irregular towards the cusps). Cusp is not clearly delineated from the adjacent lateral denticles which may reach the top of the cusp.

Reproductive system. Diaulic. Hermaphroditic duct leads to a long, moderately swollen convoluted ampulla. Vas deferens long, without a distinct prostate. Supplementary gland long, inserts into the vas a considerable distance from the elongated penial sheath. Penial sheath elongated. Penis conical, strong, unarmed. Oviduct connects through the insemination duct into the female gland complex. Very long tubular receptaculum seminis in a distal position, with a widened base and small pear-shaped reservoir (fig. 19B).

Ecology. Lives on soft bottom with stones at depths of $18-33 \mathrm{~m}$.

Distribution. High latitude arctic region of Franz Josef Land.

Remarks. See remarks for C. abyssicola abyssicola. The lowest co intergroup distance of $7.00 \%$ is found between C. abyssicola kryos subsp. nov. and $C$. sandrae sp. nov. (table 1 ). For a morphological comparison with other Cuthonella species, see table 2. 

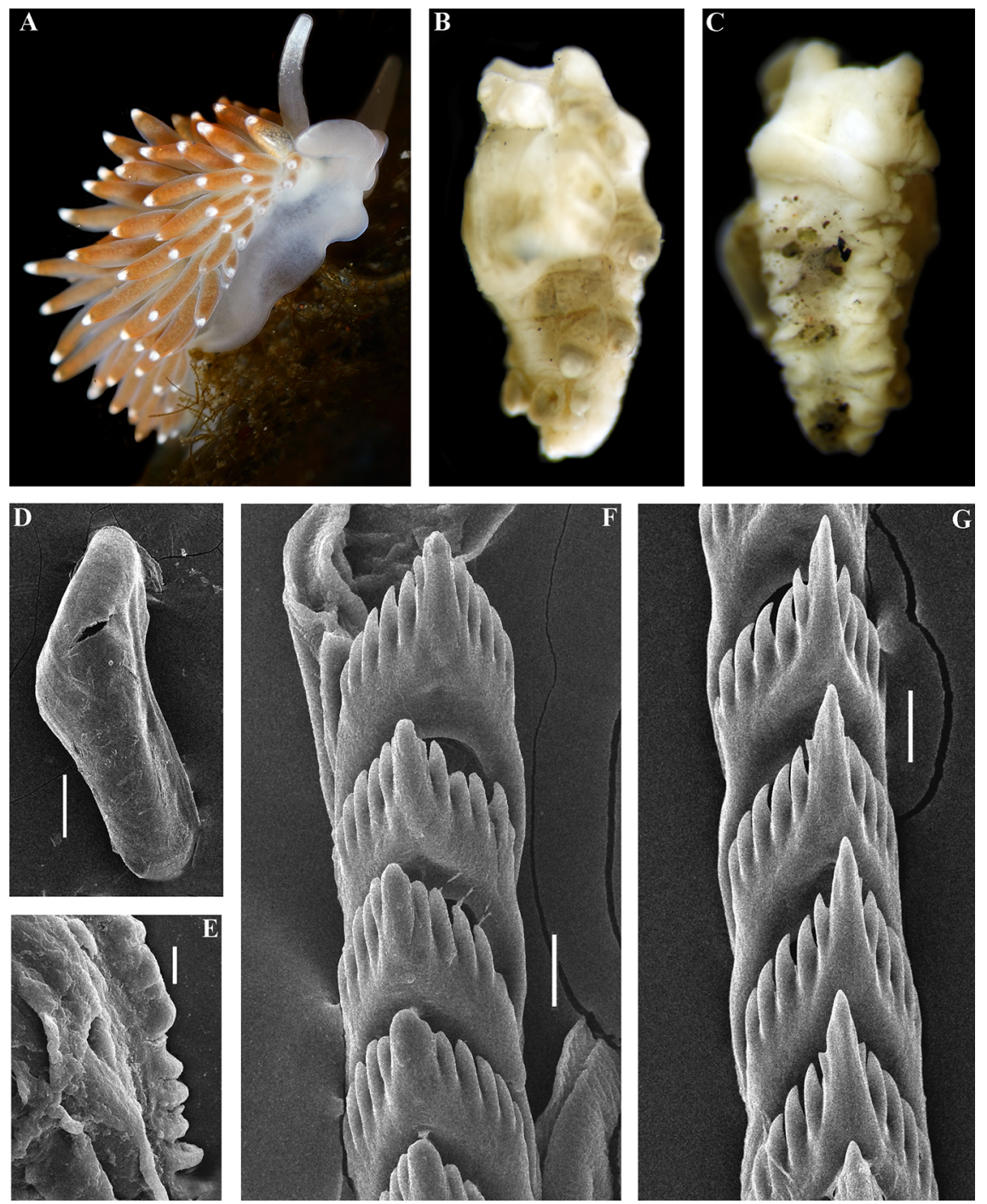

FIGURE 6 Cuthonella ainu sp. nov. A, dorsolateral view of living holotype ZMMU Op-618, Matua Island. B, C, dorsolateral and ventral views of preserved holotype, $4 \mathrm{~mm}$. D, jaw (SEM). E, jaws, details (SEM). F, anterior part of the radula (SEM). G, posterior part of the radula (SEM). Scale bars: D, $200 \mu \mathrm{m} ; \mathrm{E}, 10 \mu \mathrm{m}$; F, G, $20 \mu \mathrm{m}$. Photos: A, Nadezhda Sanamyan, B-J, Alexander Martynov.

\section{Cuthonella ainu sp. nov.}

(Figs 1, 2, 6, 19C, 21)

ZooBank:

http://urn:lsid:zoobank.

org:act:29DB6C 94-45E8-4826-9o7D${ }_{2} \mathrm{~F}_{5} \mathrm{~B} 53 \mathrm{~B} 85413$

Type material. Holotype. ZMMU Op-618, 1 spec., $L=4 \mathrm{~mm}$ length (preserved), Pacific Ocean, Middle Kuril Islands, Matua Island, Klyuv Cape, 14 m, collected by N.P. Sanamyan, 04.08.2017.
Etymology. Named in honour of the Ainu, the indigenous people of the Kuril Islands (type locality of this new species), southern Kamchatka, Sakhalin, Hokkaido and northern Honshu (Tohoku). The Ainu speak a highly isolated language, which is now critically endangered. The Ainu were forced to leave their original lands both by Japanese and Russian authorities. Ainu de facto was extinct in Russia since the early 7os, but attempts to 

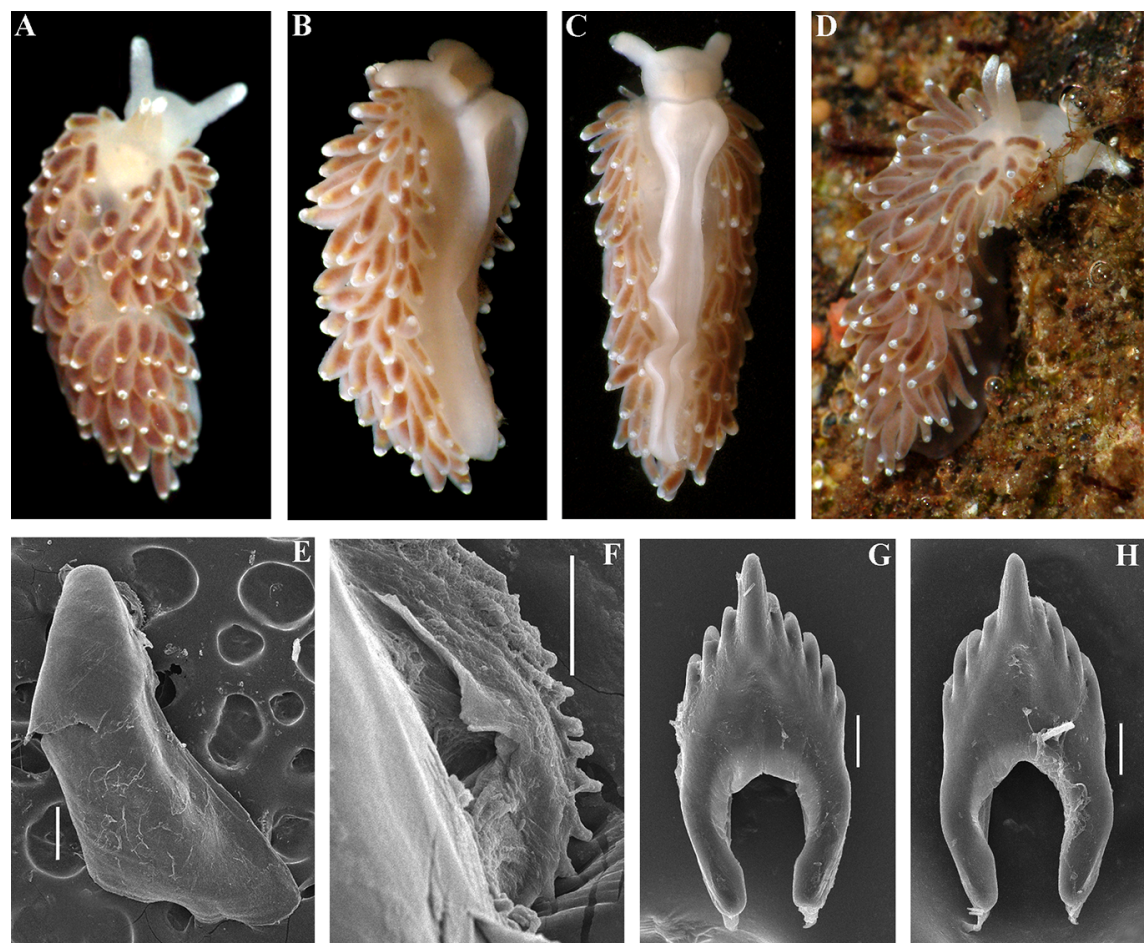

FIGURE 7 Cuthonella benedykti sp. nov. A-D, dorsal, lateral, ventral and dorsolateral views of living holotype ZMMU Op-194 from Kamchatka, 6 mm (preserved length). E, jaw (SEM). F, jaws, details (SEM). G, anterior part of the radula (SEM). H, posterior part of the radula (SEM). Scale bars: E, $200 \mu \mathrm{m} ; \mathrm{F}, 50 \mu \mathrm{m}$; G, H, $20 \mu \mathrm{m}$. Photos: A-D, Tatiana Korshunova, E-H, Alexander Martynov.

revitalize Ainu culture based on descendants withpartialAinuancestry have been carried out recently in Kamchatka without governmental support and official recognition (e.g., Tanaka, 2017). In Japan, formerly forcedly-assimilated Ainu now have governmental support for their language and culture with official recognition (Tsunemoto, 2019).

External morphology. Body moderately wide. Foot and tail broad. Oral tentacles moderate. Rhinophores similar in size to oral tentacles, smooth to slightly wrinkled. Dorsal cerata elongate, thick, arranged in a moderate number of continuous rows. Five pre-anal unbranched ceratal rows. Anal opening acleioproctic.

Colour (live). Background colour yellowish white. Digestive gland diverticula in cerata brownish to light orange. Ceratal tips with opaque white spot, sometimes with very small white spots. Rhinophores semi-transparent and covered with a dense white pigment at the top (fig. 6A).

Jaws. Jaws broad, yellowish in colour. Masticatory processes of jaws covered with a single row of distinct denticles (fig. 6D, E).

Radula. Radula formula $18 \times$ o.1.o. Central tooth elongated with a strongly protracted, pointed non-compressed cusp (fig. 6F, G). Central tooth bears up to 7 lateral denticles. Cusp clearly delineated from the adjacent first lateral denticles.

Reproductive system. Diaulic. Hermaphroditic duct leads to a relatively short, slightly bent, swollen ampulla. Vas deferens short, without a distinct prostate. Supplementary gland long, inserts into the vas deferens a short distance from the elongated penial sheath. Penis conical, unarmed. Oviduct connects through the insemination 
duct into the female gland complex. Receptaculum seminis in distal position, on a short stalk, elongate-oval (fig. 19C).

Ecology. Only found on soft bottom with stones at $14 \mathrm{~m}$ depth.

Distribution. Matua Island, Middle Kuril Islands.

Remarks. According to the molecular phylogenetic analysis Cuthonella ainu sp. nov. is closely related to $C$. benedykti sp. nov. (figs 1, 2). The maximum intragroup distance in $C$. ainu sp. nov. is $0.15 \%$. The lowest COI intergroup distance of $2.65 \%$ is found between $C$. ainu sp. nov. and C. benedykti sp. nov. (table 1). Morphological analysis reveals differences in radular patterns between $C$. benedykti sp. nov. and $C$. ainu sp. nov. (figs $6 \mathrm{~F}, \mathrm{G}$ and $7 \mathrm{G}, \mathrm{H}$ ). Externally, $C$. ainu sp. nov. differs from $C$. benedykti sp. nov. by its orangebrownish colouration and spot-shaped rather than ring-shaped patterns of the white pigment on the ceratal apices. For a morphological comparison with other Cuthonella species, see table 2.

\section{Cuthonella benedykti sp. nov.}

(Figs 1, 2, 7, 19D, 21)

ZooBank: http://urn:lsid:zoobank. org:act: ${ }_{4} \mathrm{CDE}_{4} \mathrm{~F}_{2}-\mathrm{O}_{5} \mathrm{~F}_{3}-46 \mathrm{E}_{4}-8 \mathrm{C} 6 \mathrm{~B}$ B233722AAB25

Type material. Holotype. zMMU Op-194, 1 spec., $L=6 \mathrm{~mm}$ length (preserved), Pacific Ocean, Kamchatka, Starichkov Island, 6-12 m, stones, collected by T.A. Korshunova and A.V. Martynov, 19.08.2008.

Etymology. The name is in honour of a polymath scientist of Polish origin, Benedykt Dybowski (1833-1930), who made substantial achievements especially in zoology and the anthropology of Russian Siberia and the Far East. Benedykt Dybowski belonged to the Polish intelligentsia, and he was arrested after the Polish rebellion against the Russian Empire (1863, "January Uprising") and sentenced to death, later changed to exile in Siberia, where he started his research (Wszolek et al., 1990). He also served as the only physician at the time (starting in 1879) for the large region of Kamchatka, the type locality of this new species. Among other achievements, Dybowski contributed to Kamchatka's Ainu dictionary.

External morphology. Body moderately wide. Foot and tail broad. Oral tentacles moderate. Rhinophores blunt and similar in size to oral tentacles, smooth to slightly wrinkled. Dorsal cerata elongate, thick, arranged in continuous rows. Five pre-anal unbranched ceratal rows. Anal opening acleioproctic.

Colour (live). Background colour yellowish white. Digestive gland diverticula in cerata brownish with a darker reddish to brown hue. Ceratal tips with opaque white ring or spot, sometimes with additional yellow ring, and small white spots. Rhinophores light yellowish with white pigment on the top (fig. 7A-D).

Jaws. Jaws broad, yellowish in colour. Masticatory processes of jaws covered with a single row of distinct denticles (fig. $7 \mathrm{E}, \mathrm{F}$ ).

Radula. Radula formula $36 \times$ o.1.o (specimen $6 \mathrm{~mm}$ in length). Central tooth elongated with a strongly protracted, pointed non-compressed cusp (fig. $7 \mathrm{G}, \mathrm{H}$ ). Central tooth bears up to 5 lateral denticles. Cusp clearly delineated from the adjacent first lateral denticles.

Reproductive system. Diaulic. Hermaphroditic duct leads to a relatively short, swollen ampulla. Vas deferens wide and moderate in length, without a distinct prostate. Supplementary gland relatively short, inserts into the vas deferens a short distance from the elongated penial sheath. Penis conical, unarmed. Oviduct connects through the insemination duct into the female gland complex. Receptaculum seminis in distal position, on a short stalk, oval (fig. 19D). 

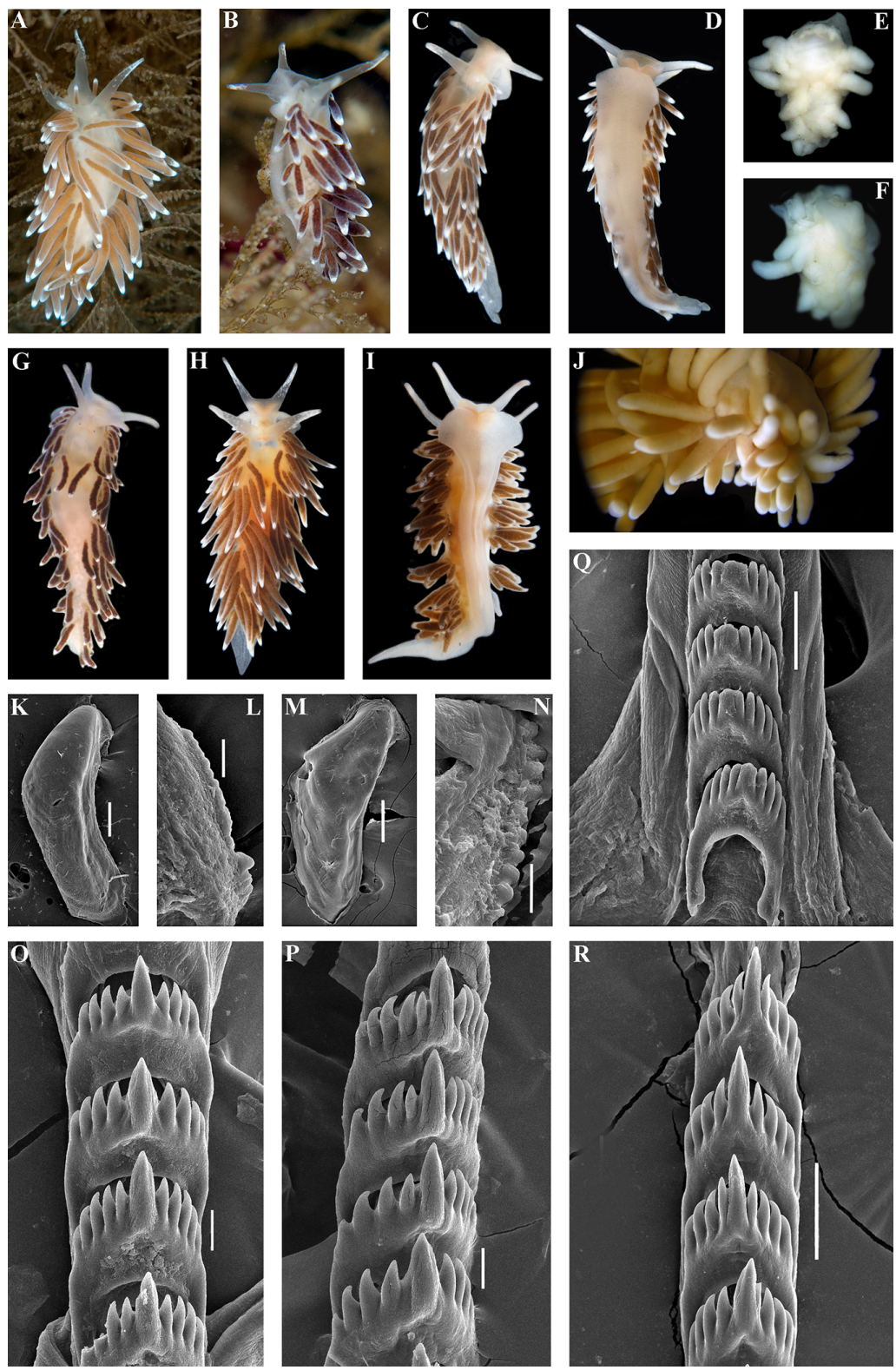

FIGURE 8 Cuthonella concinna concinna (Alder \& Hancock, 1843). A, living specimen GNM Gastropoda 8866, Sweden, 9.5 mm (preserved length), dorsal view. B, living specimen from UK, $3.5 \mathrm{~mm}$ (preserved length), laterodorsal view. C, D, living specimen from Finnmark, Norway, $12.5 \mathrm{~mm}$ (live specimen), dorsal and ventral views respectively. E, F, lectotype of "Cuthona distans", zMO D 25946, Finnmark, Norway, $3 \mathrm{~mm}$ (preserved length), dorsal and ventral views respectively. G, living specimen from the Barents Sea, Russia, $9 \mathrm{~mm}$ (preserved length), dorsal view. H, I, living specimen from the White Sea (previously identified as “C. marisalbi"), Russia, zMMU Op-523, $8 \mathrm{~mm}$ (preserved length), dorsal and ventral views respectively. J, same, lateral view of fixed specimen. K, jaw, GNM 8866, Sweden (SEM). L, same, details. M, jaw, Finnmark, Norway (SEM). N, same, details. O, anterior part of the radula, Sweden (SEM). P, posterior part of the radula, Sweden (SEM). Q, anterior part of the radula, Norway (SEM). R, posterior part of the radula, Norway (SEM). Scale bars: K, M, $200 \mu \mathrm{m} ; \mathrm{L}, \mathrm{N}, \mathrm{O}, \mathrm{P}, 20 \mu \mathrm{m} ; \mathrm{Q}, \mathrm{R}, 50 \mu \mathrm{m}$; Photos: A, Klas Malmberg, B, Bernard Picton, C-I, Tatiana Korshunova, J-R, Alexander Martynov. 
Ecology. Lives on stones at depths of $c$. 6-12 m.

Distribution. Kamchatka, Pacific side.

Remarks. According to the molecular phylogenetic analysis Cuthonella benedykti sp. nov. forms a separate clade sister to $C$. ainu sp. nov. (figs 1, 2). The maximum intragroup distance in $C$. benedykti sp. nov. is $0.16 \%$. The minimum COI intergroup distance of $2.65 \%$ is found between $C$. benedykti sp. nov. and $C$. ainu sp. nov. (Table 1). Morphological analysis reveals considerable differences in the denticulation of the central teeth between $C$. benedykti sp. nov. and its sister $C$. ainu sp. nov. as well as more distantly related, $C$.georgstelleri sp. nov., $C$. hiemalis, $C$. osyoro, and $C$. soboli (figs 6, 7, 11, 12, 14, 17). Externally, $C$. benedykti sp. nov. (fig. $7 \mathrm{~A}-\mathrm{D}$ ) differs from $C$. ainu sp. nov. (fig. 6A) by a more brownish colouration with a dark reddish hue, and more distinct ringshaped white pigment on the ceratal apices. For a morphological comparison with other Cuthonella species, see table 2.

\section{Cuthonella cocoachroma (Williams \& Gosliner, 1979) \\ Cuthona cocoachroma Williams \& Gosliner,} 1979: 204-211, figs. 3-6.

Remarks. Cuthonella cocoachroma has been described in detail by Williams \& Gosliner (1979), which will not be repeated here except to say that it differs from the sympatric $C$. concinna bellatula in having rhinophores which are twice as long as the oral tentacles, having fewer preanal ceratal rows (3-4 vs $5^{-6}$ ) and fewer ceratal rows altogether (9-10 vs 10-12), and lacking scattered white or bluish spots on its cerata. In the present material commonly up to 4 preanal rows in $C$. concinna bellatula, that make external differences from $C$. cocoachroma as more subtle. According to figure $5 \mathrm{D}$ in Williams \& Gosliner (1979), C. cocoachroma possess a supplementary gland which is inserted into the penial base instead of the vas deferens. This feature needs to be particularly commented on, because all the other 15 species of the genus Cuthonella invariably possess a supplementary gland inserted into the vas deferens and not into the penial sheath or penial base. The reproductive system of $C$. cocoachroma (not available for the present study) needs to be re-examined in this respect, considering that according to the molecular data it belongs to the genus Cuthonella (fig. 1). The thecate hydroid Thuiaria sp. was reported as a food object for $C$. cocoachroma (Goddard, 1985). The maximum intragroup distance in $C$. cocoachroma is $1.52 \%$. Interestingly, the minimum COI intergroup distance of $9.74 \%$ is found between C. cocoachroma and the allopatric $C$. punicea (table 1) rather than between the sympatric $C$. cocoachroma and $C$. concinna bellatula subsp. nov. which are externally nearly identical. For a morphological comparison with other Cuthonella species, see table 2.

\section{Cuthonella concinna concinna (Alder \&} Hancock, 1843)

(Figs 1-3, 8, 19E, 21)

Eolis concinna Alder \& Hancock, 1843: 234; Alder \& Hancock, 1845-1855: 50, fam. 3, pl. 24, plus unnumbered pages.

Cuthona concinna - Brown, 1980: 249-250, fig. $5 \mathrm{H} ; 6 \mathrm{D}, \mathrm{H}$.

Cuthona distans Odhner, 1922: 28-29, figs 11, 12, syn. nov.

Cratenopsis concinna - Nordsieck, 1972: 81.

Trinchesia concinna - Pruvot-Fol, 1954: 385 .

Cuthonella marisalbi Roginskaya, 1963: 258-264, figs 1-7; Martynov \& Korshunova, 2011: $200-201$, figs.

Cuthonella concinna - Martynov, 1992: 23; Martynov, 2006: 290; Martynov \& Korshunova, 2011: 198 -200, figs.

Type material. Natural History Museum, London, one specimen collected by Joshua Alder at Cullercoats (original type locality) and indicated as "type" (NHM, 2O2O). 
Other material. ZMMU Op-41, 2 spec., $L=9 \mathrm{~mm}$ and $5 \mathrm{~mm}$ length (preserved), Barents Sea, DalnieZelentsy, intertidal, collected byT.A. Korshunova, 08.2006. KM 452, $L=3$ mm length (preserved), Barents Sea, Dalnie Zelentsy, o.2$0.5 \mathrm{~m}$ depth, collected by T.A. Korshunova and A.V. Martynov, 05.08.2005. KM 453, $L=8 \mathrm{~mm}$ length (preserved), Barents Sea, Dalnie Zelentsy, 0.2-0.5 m depth, collected by T.A. Korshunova and A.V. Martynov, 01.08.2005. ZMMU Op-523, two spec., $L=7 \mathrm{~mm}$ and $8 \mathrm{~mm}$ length (preserved), White Sea, Rugozerskaya Bay, intertidal, collected T.A. Korshunova and A.V. Martynov, 15.06.2009. GNM Gastropoda 8866, $L=9.5 \mathrm{~mm}$ length (preserved), Skagerrak, Sweden, $5^{-10} \mathrm{~m}$ depth, collected by Klas Malmberg. KM 616, $L=3.5 \mathrm{~mm}$ length (preserved), the North Atlantic, Northern Ireland, Strangford Lough, UK, $10-20 \mathrm{~m}$ depth, collected B. Picton, 23.05.2015. ZMO D 25946 (lectotype of "Cuthona" distans), $L=3 \mathrm{~mm}$ length (preserved), Finnmark, Vadsø, collected G.O. Sars. KM 767, 1 spec., $L=12.5 \mathrm{~mm}$ (live), Finnmark, Kirkenes vicinity, intertidal, collected by T.A. Korshunova and A.V. Martynov, 29.04.2019. NTNU-VM 76078, 1 spec., Finnmark, Altafjorden, $70.156664^{\circ} \mathrm{N}$ $23.285329^{\circ} \mathrm{E}$, intertidal, collected by T.A. Korshunova, A.V Martynov, and K. Hårsaker, o8.05.2019. NTNU-VM 76o79, 1 spec., Finnmark, Altafjorden, $\quad 70.156664^{\circ} \mathrm{N} \quad 23.285329^{\circ} \mathrm{E}$, intertidal, collected by T.A. Korshunova, A.V Martynov, and K. Hårsaker, o8.o5.2019. NTNU-VM 75959, 1 spec., Finnmark, Bugøynes, $69.972744^{\circ} \mathrm{N} 29.627895^{\circ} \mathrm{E}$, intertidal, collected by T.A. Korshunova and A.V. Martynov, 29.04.2019. NTNU-VM 76oo9,1 spec., Finnmark, Porsanger, $70.245495^{\circ} \mathrm{N} 24.999314^{\circ} \mathrm{E}$, intertidal, collected by T.A. Korshunova, A.V Martynov, and K. Hårsaker, 03.05.2019. NTNU-VM 76o10, 1 spec., Finnmark, Porsanger, $70.245495^{\circ} \mathrm{N}$ $24.999314^{\circ} \mathrm{E}$, intertidal, collected by T.A. Korshunova, A.V Martynov, and K. Hårsaker, O3.05.2019. NTNU-VM 75991, 1. spec., Finnmark,
Berlevåg, $70.85021^{\circ} \mathrm{N} 29.15125^{\circ} \mathrm{E}$, intertidal, collected by T.A. Korshunova, A.V Martynov, and K. Hårsaker, o1.05.2019. NTNU-VM 76044, 1 spec., Finnmark, Kamøyvær, $71.049696^{\circ} \mathrm{N}$ $25.9125^{\circ} \mathrm{E}$, intertidal, collected by T. Bakken, C. Skauge, 05.05.2019. NTNU-VM 76045, 2 spec., Finnmark, Kamøyvær, $71.049696^{\circ} \mathrm{N}$ $25.91252^{\circ} \mathrm{E}$, intertidal, collected by T. Bakken, C. Skauge, 05.05.2019. NTNU-VM 75960, 1 spec., Finnmark, Bugøynes, $69.972744^{\circ} \mathrm{N}$ $29.627895^{\circ} \mathrm{E}$, intertidal, collected by T.A. Korshunova and A.V. Martynov, 29.04.2019. NTNU-VM 75981, 1. spec., Finnmark, Berlevåg, $70.850088^{\circ} \mathrm{N} 29.154291^{\circ} \mathrm{E}$, intertidal, collected by T. Bakken, T.A. Korshunova, A.V. Martynov, and K. Hårsaker, 30.04.2019. NTNU-VM 75992, 1. Spec., Finnmark, Berlevåg, $70.85021^{\circ} \mathrm{N}$ $29.15125^{\circ} \mathrm{E}$, intertidal, collected by T.A. Korshunova, A.V Martynov, and K. Hårsaker, o1.05.2019. NTNU-VM 75994, 4. Spec., Finnmark, Berlevåg, $70.85021^{\circ} \mathrm{N} 29.15125^{\circ} \mathrm{E}$, intertidal, collected by T.A. Korshunova, A.V Martynov, and K. Hårsaker, 01.05.2019.

External morphology. Body moderately wide.

Foot and tail broad. Rounded foot corners present. Oral tentacles moderate. Rhinophores similar in size, or slightly longer than oral tentacles, smooth to slightly wrinkled. Dorsal cerata elongate, arranged in continuous rows. Up to 6 pre-anal unbranched ceratal rows. Anal opening acleioproctic.

Colour (live). Background colour yellowish white. Digestive gland diverticula in cerata brown to purplish-brown. Ceratal tips with opaque white subapical band or spot, sometimes with a bluish hue and smaller white spots. Rhinophores and oral tentacles semi-transparent with commonly white pigment on the tips (fig. 8A-D, G-I).

Jaws. Jaws broad, yellowish in colour. Masticatory processes of jaws covered with a single row of distinct denticles (fig. $8 \mathrm{~K}-\mathrm{N}$ ).

Radula. Radula formula $30 \times 0.1 .0$ (specimen $8 \mathrm{~mm}$ in length), $29 \times$ 0.1.o (specimen $9.5 \mathrm{~mm}$ 
in length), $19 \times 0.1 .0$ (specimen $3 \mathrm{mmin}$ length), $26 \times$ 0.1.o (specimens $8 \mathrm{~mm}$ in length). Central tooth elongated with a strongly protracted cusp (fig. 80-R). Central tooth bears up to 10 lateral denticles (more commonly, up to $4-5$ ). Cusp clearly delineated from the adjacent first lateral denticles.

\section{Reproductive}

system.

Diaulic. Hermaphroditic duct leads to a relatively short or folded swollen ampulla. Vas deferens relatively long, without a distinct prostate. Supplementary gland usually relatively long, sometimes shorter, inserts into the vas deferens at a relatively short distance from the elongated penial sheath. Penis conical, unarmed. Oviduct connects through the insemination duct into female gland complex. Receptaculum seminis in a more proximal position than in most other Cuthonella species, and on a short stalk, without a distinct reservoir (fig. 19E).

Ecology. Lives on stones and rocks. Intertidal to $30 \mathrm{~m}$ depth.

Distribution. Boreal European waters of the NE Atlantic (France, British Isles, Netherlands, Denmark, Sweden, Norway to the Barents Sea and the White Sea in Russia) and the Atlantic coast of the USA and Canada.

Remarks. In the present study we obtained morphological and molecular data from specimens of $C$. concinna concinna from the British Isles (the type locality of this subspecies) and thereby confirm that it is conspecific with our other specimens from different localities across the North Atlantic. Present molecular phylogenetic analysis (figs 1,2) hereby confirms that $C$. concinna concinna has an amphiatlantic distribution, but North Pacific populations belong to the separate subspecies $C$. concinna bellatula subsp. nov. (see details below). The range of $C$. concinna concinna is confirmed here from the White Sea to the Northeast Atlantic coast, including occurrences in Eastern Canada, the Netherlands, Norway, Russia, Sweden, the UK, and the Eastern USA.
In this study we also obtained recently collected specimens (fig. 8C, D) from the type locality of the enigmatic Norwegian species Cuthona distans Odhner, 1922 in the northernmost mainland Norwegian county of Finnmark. We also studied the type specimen of $C$. distans from the Oslo Natural History Museum in Norway (ZMO D 25946, designated here as the lectotype) (fig. 8E, F). According to the morphological study of the type material of $C$. distans, it has a supplementary gland that inserts into the vas deferens relatively close to the penis, similar to that of $C$. concinna concinna. Molecular analysis shows that new specimens from Finnmark belong to $C$. concinna concinna (figs 1-3). Morphological data from the original description of $C$. distans (Odhner, 1922) and our study of the type material also confirm that $C$. distans syn. nov. is a junior synonym of $C$. concinna concinna. In the northern localities such as the Barents Sea and the Finnmark region, $C$. concinna concinna is one of the most common shallow-water species of nudibranchs. Several thecate hydroid species of the families Campanulariidae and Sertulariidae were reported as food objects for $C$. concinna concinna: Diphasia fallax (Johnston, 1847), Dynamena pumila (Linnaeus, 1758), Sertularia spp. (Roginskaya, 1987; Martynov \& Korshunova, 2011), Hartlaubella gelatinosa (Pallas, 1766), Laomedea flexuosa Alder, 1857, Obelia longissima (Pallas, 1766), Sertularia argentea Linnaeus, 1758, Sertularia cupressina Linnaeus, $175^{8}$ (Alder \& Hancock, 1845-1855; Swennen, 1961; Brown, 1980; Thompson \& Brown, 1984; Picton \& Morrow, 1994). A report of the feeding on the athecate Tubularia indivisa Linnaeus, $175^{8}$ (Hamond, 1972) needs a verification.

The maximum intragroup distance in $C$. concinna concinna is $0.91 \%$. The minimum COI interspecies distance of $9.28 \%$ is found between C. concinna concinna and C. vasentsovichi 

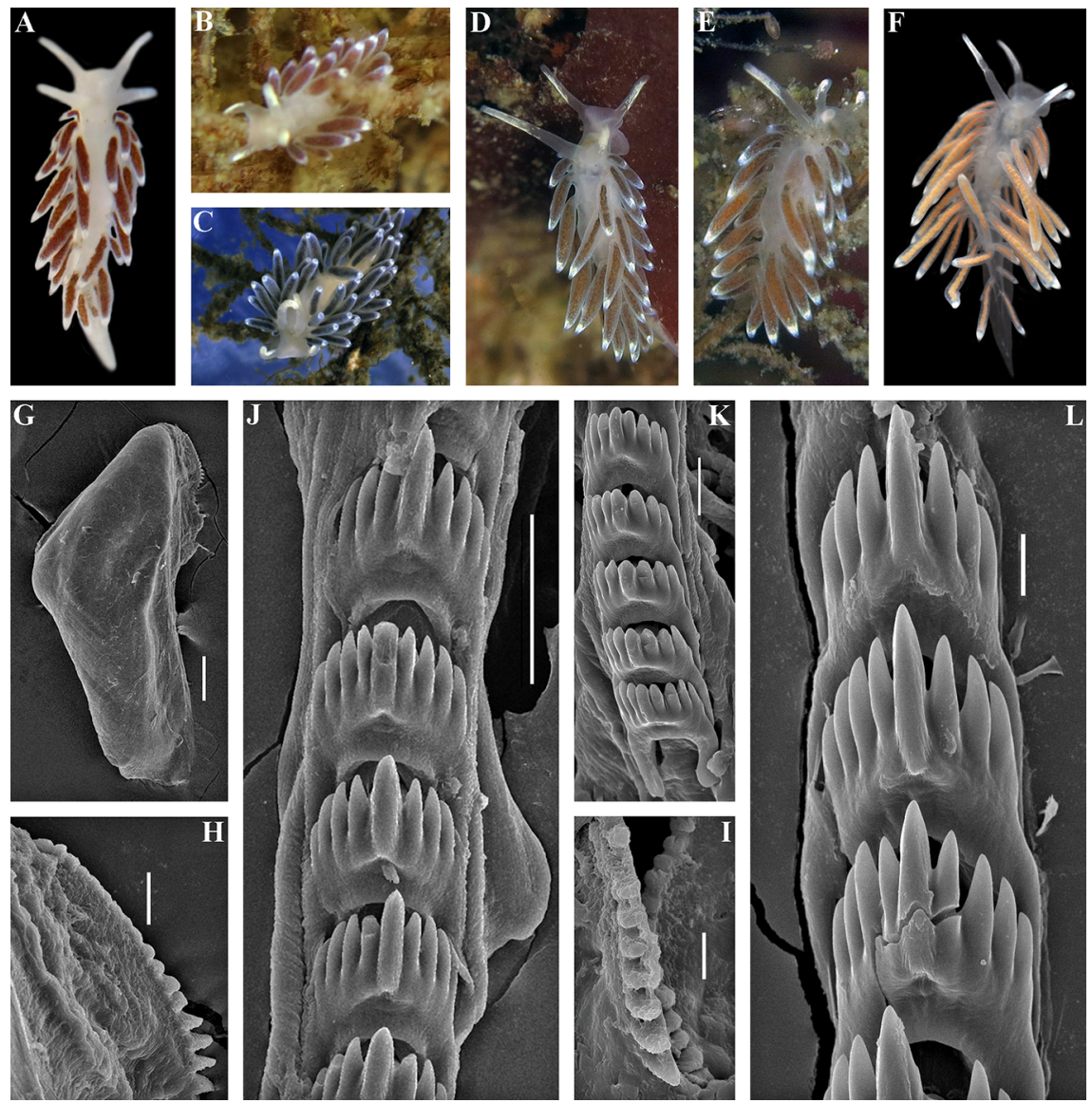

FIGURE 9 Cuthonella concinna bellatula subsp. nov. A, living holotype ZMMU Op-729 from the NE Pacific, Port Orchard, USA, $6 \mathrm{~mm}$ (live length), dorsal view. B, living holotype in natural conditions. C, living paratype ZMMU Op-728 in natural conditions on a hydroid of the family Sertulariidae, Port Orchard, USA, $8 \mathrm{~mm}$ (live length), dorsolateral view. D, E, two living paratypes zMmu Op-742, 5-6 mm (live length), dorsal view in natural conditions, including hydroid of the family Sertulariidae (E). F, living paratype zMMU Op-740, Port Orchard, USA, 7 mm (live length), dorsal view. G, jaw, paratype ZMMU Op-728 (sEM). H, same, details. J, anterior and middle parts of radula of paratype ZMMU Op-728 (SEM). K, same, anterior part of the radula (SEM). I, jaw, details of the paratype ZMMU Op-74O (SEM). $\mathrm{L}$, posterior part of the radula paratype zMMU Op-74O (sEM). Scale bars: G, $100 \mu \mathrm{m} ; \mathrm{H}, \mathrm{K}, 20 \mu \mathrm{m}$; I, L,10 $\mu \mathrm{m} ; \mathrm{J}, 50 \mu \mathrm{m}$; Photos: A-F, Karin Fletcher, G-L, Alexander Martynov.

sp. nov. (Table 1). Morphologically, the nominative subspecies differs from $C$. concinna bellatula subsp. nov. by its larger maximum body size (20 $\mathrm{mm}$ compared to $15 \mathrm{~mm}$ ), and a larger number of lateral denticles of the central teeth of the radula. We also checked several specimens of $C$. concinna s.l. from different locations over large geographic distances, but were unable to confirm the presence of a narrow distal "bursa" (in addition to the receptaculum) reported for this species by Williams \& Gosliner (1979). The reason the receptaculum in $C$. concinna s.l. (figs $19 \mathrm{E}, \mathrm{F}$ ) appears to be placed in a more proximal position than in the majority of Cuthonella species (figs 19, 20) is possibly because a channel from the receptaculum to the female opening is partially concealed within female gland mass. For a morphological comparison with other Cuthonella species, see table 2. 
Cuthonella concinna bellatula subsp. nov.

(Figs 1-3, 9, 19F, 21)

ZooBank:

http://urn:lsid:zoobank.

org:act:8 2 CF $5393-\mathrm{CF} 70-42 \mathrm{DF}-\mathrm{A} 95 \mathrm{~A}-$ $\mathrm{E} 8869 \mathrm{~B} 4 \mathrm{FBED} 8$

Cuthonella concinna s.l. auct., e.g. O'Donoghue, 1922: 162-163; Millen, 1983: 384; Behrens, 1980: 98; Korshunova et al., 2018a: 317, non Alder \& Hancock, 1843

Type material. Holotype. ZMMU Op-729, $L=6 \mathrm{~mm}$ length (live), NE Pacific, Rich Passage, West of Pt. Glover, c. $12 \mathrm{~m}$ depth, collected by Karin Fletcher, 13.07.2013.

Paratypes. ZMMU Op-728, one spec., $L=8 \mathrm{~mm}$ length (live), NE Pacific, Rich Passage, Port Orchard, $10.7 \mathrm{~m}$, collected by Karin Fletcher, 18.04.2012. ZMMU Op-74O, one spec., $L=7 \mathrm{~mm}$ length (live), NE Pacific, Rich Passage, West of Pt. Glover, $c .10 \mathrm{~m}$ depth, collected by Karin Fletcher, 02.02.2019. ZMMU Op-742, two spec., $L=5^{-6} \mathrm{~mm}$ length (live), NE Pacific, Rich Passage, West of Pt. Glover, c. $10 \mathrm{~m}$ depth, collected by Karin Fletcher, 30.04.2014.

Etymology. From Latin bellatula ("small beautiful") referring to the morphological similarity, but smaller size, compared to the nominative subspecies $C$. concinna concinna, for which the name "concinna" has a similar meaning in Latin, "beautiful, well-proportionated".

External morphology. Body moderately narrow. Foot and tail moderate. Rounded foot corners present. Oral tentacles moderate. Rhinophores similar in size, or slightly longer than oral tentacles, smooth to slightly wrinkled. Dorsal cerata elongate, arranged in continuous rows. Potentially up to 6 , but in present material commonly up to 4 pre-anal unbranched ceratal rows. Anal opening acleioproctic.

Colour (live). Background colour white to yellowish white. Digestive gland diverticula pinkish, brownish-orange, reddish, grayishpurple to blackish. Cerata can have a bluish sheen and a few scattered white or bluish spots. Ceratal tips with opaque white spots or bands. Rhinophores and oral tentacles semitransparent with white pigment on the tips (fig. 9A-F).

Jaws. Jaws broad, yellowish in colour. Masticatory processes of jaws covered with a single row of distinct denticles (fig. $9 \mathrm{G}, \mathrm{H}, \mathrm{I}$ ).

Radula. Radula formula about $17 \times$ 0.1.o (specimen $8 \mathrm{~mm}$ in length), Central tooth elongate with protracted, pointed noncompressed cusp(fig. 9J, K,L). Central tooth bears 3-5 lateral denticles. Cusp clearly delineated from the adjacent first lateral denticles.

Reproductive system. Diaulic. Hermaphroditic duct leads to a short, swollen ampulla. Vas deferens short, without a distinct prostate. Supplementary gland short, inserts into the vas deferens a relatively long distance from the elongated penial sheath. Penis conical, unarmed. Oviduct connects through the insemination duct into the female gland complex. Receptaculum seminis in a more proximal position than in most other Cuthonella species, and on a short stalk, with only a weakly defined reservoir (fig. 19F).

Ecology. Lives on stones and rocks at depths of $c$. 10-15 m, primarily found between March-September on its prey, the hydroids of the family Sertulariidae.

Distribution. Temperate NE Pacific waters from Alaska to Sonoma County, California.

Remarks. Morphologically C. concinna bellatula subsp. nov. differs from the nominative subspecies by its smaller maximum body size $(15 \mathrm{~mm}$ compared to $20 \mathrm{~mm}$ ), more varied ceratal colour (in $C$. concinna bellatula subsp. nov. the ceratal colour ranges from pinkish to brownishorange, reddish, grayish-purple to blackish, whereas in $C$. concinna concinna the colour is a rather uniform brownish to dark brown) and fewer number of lateral denticles on the central teeth of the radula (in $C$. concinna 

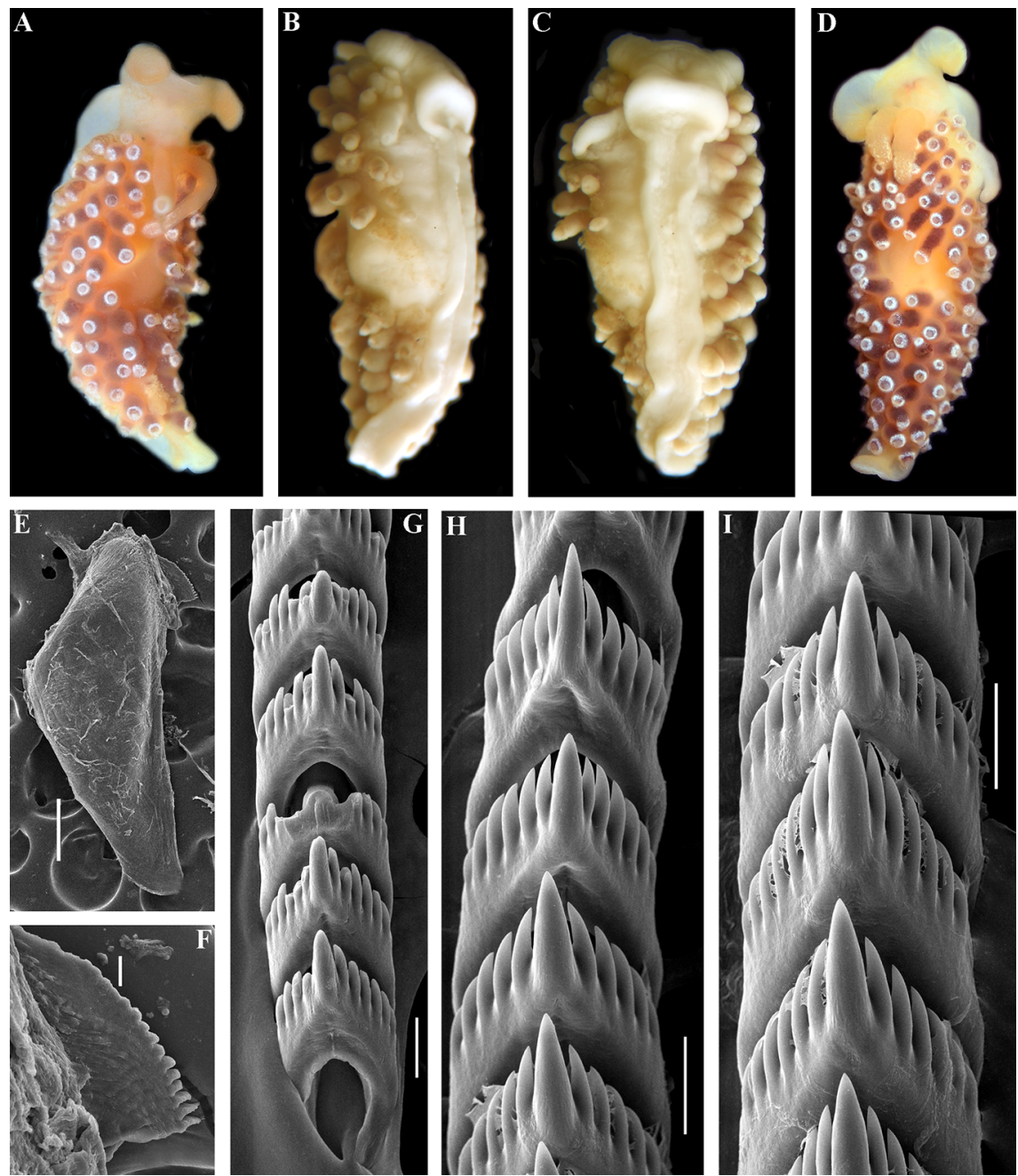

FIGURE 10 Cuthonella denbei sp. nov. A, living holotype zMmU Op-73o, $6 \mathrm{~mm}$ (preserved length), Matua Island, dorsal view. B, preserved holotype, lateral view. C, preserved holotype, ventral view. D, living paratype Op-741, 7 mm (preserved length), Matua Island, dorsal view. E, jaw, paratype ZMmU Op-673 (sEM). F, jaw, same, details. G, anterior part of the radula of the paratype zMmU Op-673 (SEM). H, I, middle and posterior part of the radula of the paratype zMMU Op-673 respectively (SEM). Scale bars: E, $200 \mu \mathrm{m}$; F, $20 \mu \mathrm{m}$; G-I, $30 \mu \mathrm{m}$; Photos: A, B, Nadezhda Sanamyan, C-I, Alexander Martynov.

bellatula subsp. nov. the number of lateral denticles is commonly no more than 5 , whereas in the nominative subspecies the number of denticles can reach up to 10).

Cuthonella concinna bellatula and $C$. cocoachroma are also likely to be mistaken for each other. These two species are so similar externally that two of the five specimens collected at the same time in Sonoma County,
California (CASIZ 181307a and CASIZ 181307d), plus another specimen collected from the same site on a different date (CASIZ 179469), all putatively considered to be $C$. cocoachroma when they were collected, turned out to be C. concinna (named C. concinna bellatula in this paper). These results were not discussed in details within the study which originally sequenced the specimens (Cella et al., 2016) 
but until then the southernmost limit of the range of $C$. concinna bellatula was Vancouver Island, British Columbia, Canada. A record of Cuthonella concinna s.l. from the Commander Islands (Martynov, 1997) may also include a different species and needs further investigation. Several hydroid species were previously reported as food objects for NE Pacific C. concinna s.l.: Bougainvillia glorietta Torrey, 1904, Obelia commissuralis McCrady, 1859 (currently also mentioned as Obelia dichotoma (Linnaeus, 1758)), Coryne eximia Allman, 1859 (Waters, 1966), and Sertularia sp. (Behrens \& Hermosillo, 2005). These reports need verification. In the present study we found C. concinna bellatula subsp. nov. on hydroids of the family Sertulariidae.

The maximum intragroup distance in $C$. concinna bellatula subsp. nov. is $1.67 \%$. At the same time, the minimum intergroup distance between $C$. concinna concinna and $C$. concinna bellatula subsp. nov. is $1.07 \%$. A considerable intragroup genetic divergence suggests that the present North Pacific populations of $C$. concinna bellatula subsp. nov. may conceal potentially more taxonomic diversity and may also have experienced a genetic introgression with Atlantic C. concinna concinna occasionally introduced to the Pacific coast. While making a decision on the taxonomic status of " $C$. concinna" from the NE Pacific we encountered a difficult situation because of the lack of a clear and universal definition of a "species" concept. "Cuthonella concinna" from the NE Pacific is case of a "species" (or a part of a group of species) which has likely only relatively recently started to diverge into a separate species, where specimens already show some morphological and molecular differences from $C$. concinna concinna, but these differences are not distinct enough for a full species status.

At the same time, a clear and significant geographic gap was revealed in the case of
C. concinna bellatula subsp. nov. from the NE Pacific compared to the location of the nominative subspecies. In our opinion, the best decision in this case was the separation of such forms as subspecies, which meets the requirements of both the ICZN and general taxonomic practice when subspecies status commonly implies a considerable geographic separation. It is possible that with a really large dataset this decision can be clarified, but given the amount of currently available data we prefer to consider it a subspecies. The maximum intragroup distance in $C$. concinna bellatula is $1.67 \%$. The minimum COI intergroup distance of $9.74 \%$ is found between C. concinna bellatula subsp. nov. and $C$. vasentsovichi sp. nov. (table 1). For a morphological comparison with other Cuthonella species, see table 2.

\section{Cuthonella denbei sp. nov.}

(Figs 1, 2, 10, 2०A, 21)

ZooBank: http://urn:lsid:zoobank.org:act:9DD9o2C3-B8CA-4941-9712-11E77977DB77

Type material. Holotype. zMMU Op-73о, $L=6 \mathrm{~mm}$ length (preserved), Pacific Ocean, Middle Kuril Islands, Matua Island, Klyuv Cape, intertidal, collected by N.P. Sanamyan, o6.08.2017.

Paratypes. ZMMU Op-674, 1 spec., $L=4.5 \mathrm{~mm}$ length (preserved), Pacific Ocean, Middle Kuril Islands, Matua Island, Klyuv Cape, intertidal, collected by N.P. Sanamyan, 22.08.2016. zMMU Op-673, 1 spec., $L=4 \mathrm{~mm}$ length (preserved), Pacific Ocean, Middle Kuril Islands, Matua Island, Klyuv Cape, 16 m depth, on brown algae Thalassiophyllum clathrus, collected by N.P. Sanamyan, 23.08.2016. zMMU Op-741, 1 spec., $L=7 \mathrm{~mm}$ length (preserved), Pacific Ocean, Middle Kuril Islands, Matua Island, Klyuv Cape, intertidal, collected by N.P. Sanamyan, o6.08.2017.

Etymology. Named in honour of the Japanese merchant clerk Denbei (Dembei) - 
伝兵衛（でんべえ）(c.1670-1714） from Osaka who represented the first welldocumented case of the appearance of a Japanese native in Russia. Denbei arrived in Russia due to the shipwrecking of a Japanese vessel on the Kamchatka coast, followed by a long drift through the Kuril Islands chain, the type locality of the present species. Afterwards, Denbei had an audience with the Russian tsar Peter the Great in 1702. This became an historic event since Denbei promoted the first official connections between Japan and Russia, and also established the first school of Japanese language in Russia (e.g., Ikuta, 2008).

External morphology. Body moderately narrow. Foot and tail broad. Oral tentacles moderate. Rhinophores similar in size to oral tentacles, smooth to slightly wrinkled. Dorsal cerata elongate, thick, arranged in continuous rows. Up to 6 pre-anal unbranched ceratal rows. Anal opening acleioproctic.

Colour (live). Background colour yellowish to more intense yellow-pinkish. Digestive gland diverticula within cerata brownish to dark-reddish. Ceratal tips with distinct ringshaped opaque white pigment, sometimes with few scattered white spots. Rhinophores light yellowish with a sparse white pigment at the top (fig. 10A, B).

Jaws. Jaws broad, yellowish in colour. Masticatory processes of jaws covered with a single row of distinct denticles (fig. 1oE, F).

Radula. Radula formula $19 \times$ 0.1.o (specimen $4 \mathrm{~mm}$ in length). Central tooth elongated with a strongly protracted, pointed non-compressed cusp (fig. 10G-I). Central tooth bears up to 7 lateral denticles. Cusp clearly delineated from the adjacent first lateral denticles.

Reproductive system. Diaulic. Hermaphroditic duct leads to a relatively short, swollen ampulla. Vas deferens moderately long, without a distinct prostate. Supplementary gland relatively short, inserts into the vas deferens a considerable distance from the elongated penial sheath. Penis conical, unarmed. Oviduct connects through the insemination duct into the female gland complex. Receptaculum seminis in a distal position, on a short stalk, pear-shaped (fig. 20A).

Ecology. Lives on soft bottoms with stones. Intertidal to $16 \mathrm{~m}$ depth.

Distribution. Matua Island, Middle Kuril Islands.

Remarks. The maximum intragroup distance in $C$. denbei sp. nov. is $0.30 \%$. The minimum COI intergroup distance of 9.30\% is found between $C$. denbei sp. nov. and $C$. concinna concinna (table 1). Morphological analysis reveals considerable differences in the denticulation of the central teeth between $C$. denbei sp. nov. and related species $C$. benedykti, $C$. georgstelleri sp. nov., $C$. hiemalis sp. nov., $C$. osyoro, and $C$. soboli (figs $7,11,12$, 14, 17). For a morphological comparison with other Cuthonella species, see table 2.

\section{Cuthonella elenae Martynov, 2000}

Cuthonella elenae Martynov, 2000: 5-9, Figs 1-3; Martynov, 20o6b: 290.

Remarks. Cuthonella elenae from the Chukchi Sea has been described in detail in Martynov (2000), which will not be repeated here. This species has all the diagnostic characters of the genus Cuthonella, including a supplementary gland inserted into the vas deferens, which unambiguously places this species in the genus Cuthonella, even in the absence of molecular data. At the same time, this species evidently shows several unique features, including small lobes around the penial opening, a very broad penial sheath, a relatively short supplementary gland, and flattened oral tentacles.

These characters clearly delineate this species from any other Cuthonella species, including the newly-described ones in 

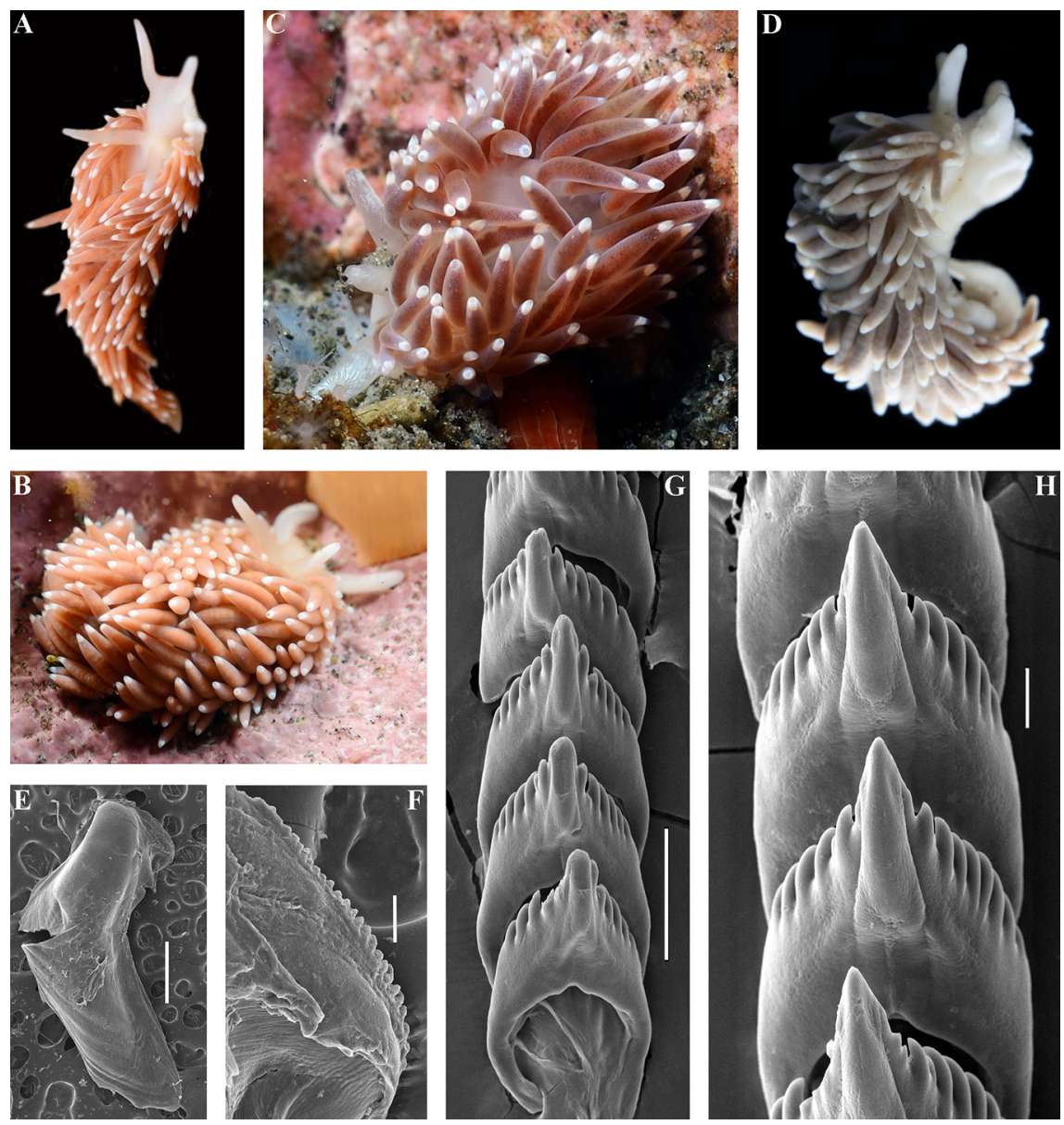

FIGURE 11 Cuthonella georgstelleri sp. nov. A, B, living holotype ZMMU Op-670, Matua Island, 14 mm (preserved length), dorsal and dorsolateral views respectively. C, Living paratype zмMU Op-731, Matua Island, $10 \mathrm{~mm}$ (preserved length), dorsal view. D, Preserved paratype ZMMU Op-731, lateral view. E, jaw, holotype (SEM). F, jaw, same, details. G, anterior part of the radula of the holotype (SEM). H, posterior part of the radula of the holotype (SEM). Scale bars: E, $500 \mu \mathrm{m} ; \mathrm{F}, 50 \mu \mathrm{m} ; \mathrm{G}, 100 \mu \mathrm{m} ; \mathrm{H}, 30 \mu \mathrm{m}$; Photos: A-C, Nadezhda Sanamyan, D-H, Alexander Martynov.

this study. By the presence of the manybranched digestive gland, this species shares a common plesiomorphic condition with the type species, $C$. abyssicola s.l. There are no additional specimens collected since the original description, and molecular phylogenetic data are not available for this species. For a morphological comparison with other Cuthonella species, see table 2.

\section{Cuthonella georgstelleri sp. nov.}

(Figs 1, 2, 11, 20B, 21)
ZooBank:

http://urn:lsid:zoobank. org:act:FF 4OFDD 4-CF8D-4758-899A6D2A548E686B

Type material. Holotype. ZMMU Op-670, 1 spec., $L=14 \mathrm{~mm}$ length (preserved), Pacific Ocean, Middle Kuril Islands, Matua Island, Klyuv Cape, $16 \mathrm{~m}$ depth, collected by N.P. Sanamyan, 28.o8.2016.

Paratypes. ZMMU Op-672, 1 specimen, $L=12 \mathrm{~mm}$ length (preserved), same locality, date and collector as holotype. ZMMU Op-731, 1 spec., $L=10 \mathrm{~mm}$ length (preserved), Pacific 

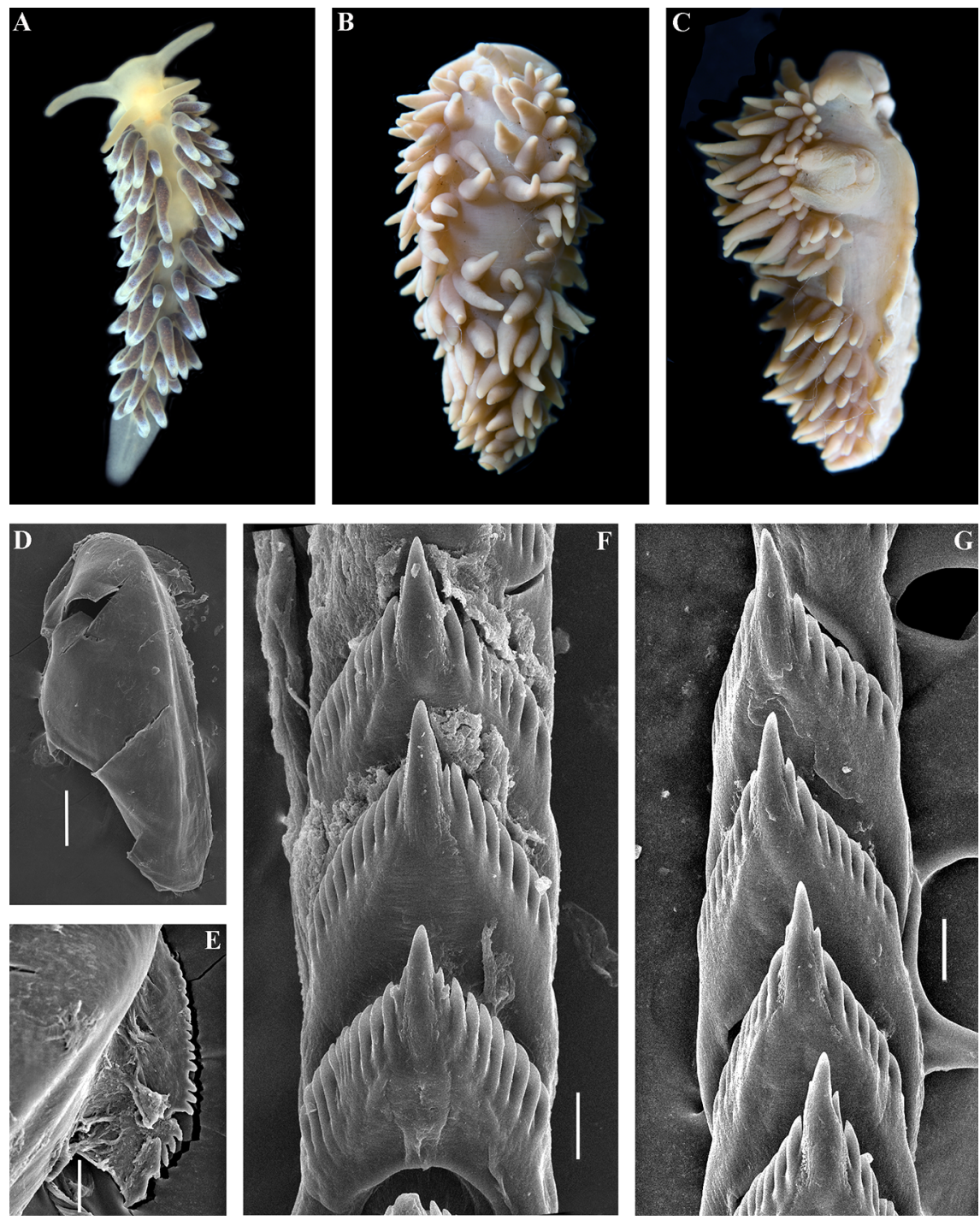

FIGURE 12

Cuthonella hiemalis (Roginskaya, 1987). A, living specimen from the type locality, White Sea, dorsal view, $c .5 \mathrm{~mm}$ (preserved length). B, C. preserved syntype collected and identified by I.S. Roginskaya, ZMMU Op-732, White Sea, $14 \mathrm{~mm}$ (preserved length), dorsal and lateral views respectively. D, jaw, zMMU Op-732 (SEM). E, jaw, same, details. F, anterior part of the radula, zMMU Op-732 (SEM). G, posterior part of the radula, same (SEM). Scale bars: D, $200 \mu \mathrm{m}$; E, $50 \mu \mathrm{m}$; F, G, $20 \mu \mathrm{m}$; Photos: A, courtesy of Anna Zhadan, B-G, Alexander Martynov.

Ocean, Middle Kuril Islands, Matua Island, Klyuv Cape, $14 \mathrm{~m}$ depth, collected by N.P. Sanamyan, 20.08.2017.

Etymology. The name is in honour of the prominent 18th-century scientist Georg Wilhelm Steller (1709-1746) of German origin who served in the Russian Empire and made substantial efforts to study the North Pacific region, and particularly the Kuril and Commander Islands, but met a very unfortunate fate. Georg Steller was the only professional scientist who saw and personally described the now extinct Steller's sea cow (Hydrodamalis gigas). Georg Steller is also 
considered the first European who stepped onto the land of Alaska (Stejneger, 1936). In 1742, Georg Steller was falsely accused of organizing a rebellion against the Russian Government in Kamchatka and was forced to return to mainland Russia, but on the way to Moscow he died in the Siberian area of Tyumen. The majority of the descriptions of his collected materials and prepared notes (in his diaries) was published after his death.

External morphology. Body moderately wide. Foot and tail broad. Oral tentacles moderate. Rhinophores similar in size to oral tentacles, smooth to slightly wrinkled. Dorsal papillae elongate, thick, arranged in continuous rows. Up to 8 pre-anal unbranched or partially branched ceratal rows. Anal opening cleioproctic.

Colour (live). Background colour whitish. Digestive gland diverticula light orangebrownish and salmon-brownish to dark, intensive brownish reddish. Ceratal tips with extended opaque white band or spot, sometimes with few white small spots. Rhinophores whitish to light yellowish with slight disperse white pigment (fig. 11A-C).

Jaws. Jaws broad, yellowish in colour. Masticatory processes of jaws covered with a single row of denticles (fig. $11 \mathrm{E}, \mathrm{F}$ ).

Radula. Radula formula $30 \times$ 0.1.0 (specimen $14 \mathrm{~mm}$ in length). Central tooth elongated with a strongly protracted, pointed non-compressed cusp (fig. $11 \mathrm{G}, \mathrm{H}$ ). Central tooth bears up to 10 lateral denticles. Cusp clearly delineated from the adjacent first lateral denticles.

\section{Reproductive system. Diaulic.} Hermaphroditic duct leads to a relatively short, swollen ampulla. Vas deferens moderate in length, without a distinct prostate. Supplementary gland long, inserts into the vas deferens at a considerable length from the elongated penial sheath. Penis conical, unarmed. Oviduct connects through the insemination duct into the female gland complex. Receptaculum seminis distal, on a long stalk, compressed (fig. 2oB).

Ecology. Lives on soft bottoms with stones at depths of 14-16 m.

Distribution. Matua Island, Middle Kuril Islands.

Remarks. The maximum intragroup distance in C. georgstelleri sp. nov. is $0.30 \%$. The minimum coI intergroup distance of $7.75 \%$ is found between $C$. georgstelleri sp. nov. and $C$. benedykti sp. nov. (table 1). Phylogenetically, C. georgstelleri sp. nov. is close to $C$. soboli, $C$. osyoro, $C$. ainu sp. nov., and $C$. benedykti sp. nov. Morphological analysis reveals considerable differences in the denticulation of the central teeth between C. georgstelleri and the related species $C$. ainu sp. nov., $C$. hiemalis, $C$. osyoro and $C$. soboli (figs $6,12,14,17)$. For a morphological comparison with other Cuthonella species, see table 2.

\section{Cuthonella hiemalis (Roginskaya, 1987)}

(Figs 1, 2, 12, 20C, 21)

Cuthona hiemalis Roginskaya, 1987: 197-199; Fig. 118 was supposed to illustrate this species in the original description, but it was omitted in the publication due to an editorial error.

Cuthonella hiemalis (Roginskaya, 1987) Martynov, 1992: 23; Martynov, 2006b: 29o; Martynov \& Korshunova, 2011: 195-197, figs.

Type material. The previously indicated (Martynov, 20o6b) syntypes series (including labelled, but not published by Roginskaya (1987) "holotype") is not traceable. A syntype was discovered, accompanied by a label written by I.S. Roginskaya. The syntype was collected over the same period of time in the same locality with the previously mentioned type series: ZMMU Op-732, $L=14 \mathrm{~mm}$ (preserved), White Sea, Rugozerskaya Bay, intertidal, collected by I.S. Roginskaya, 7.02.1962.

Other materials. ZMMU Op-186, eggmass and juveniles (preserved), White Sea, 

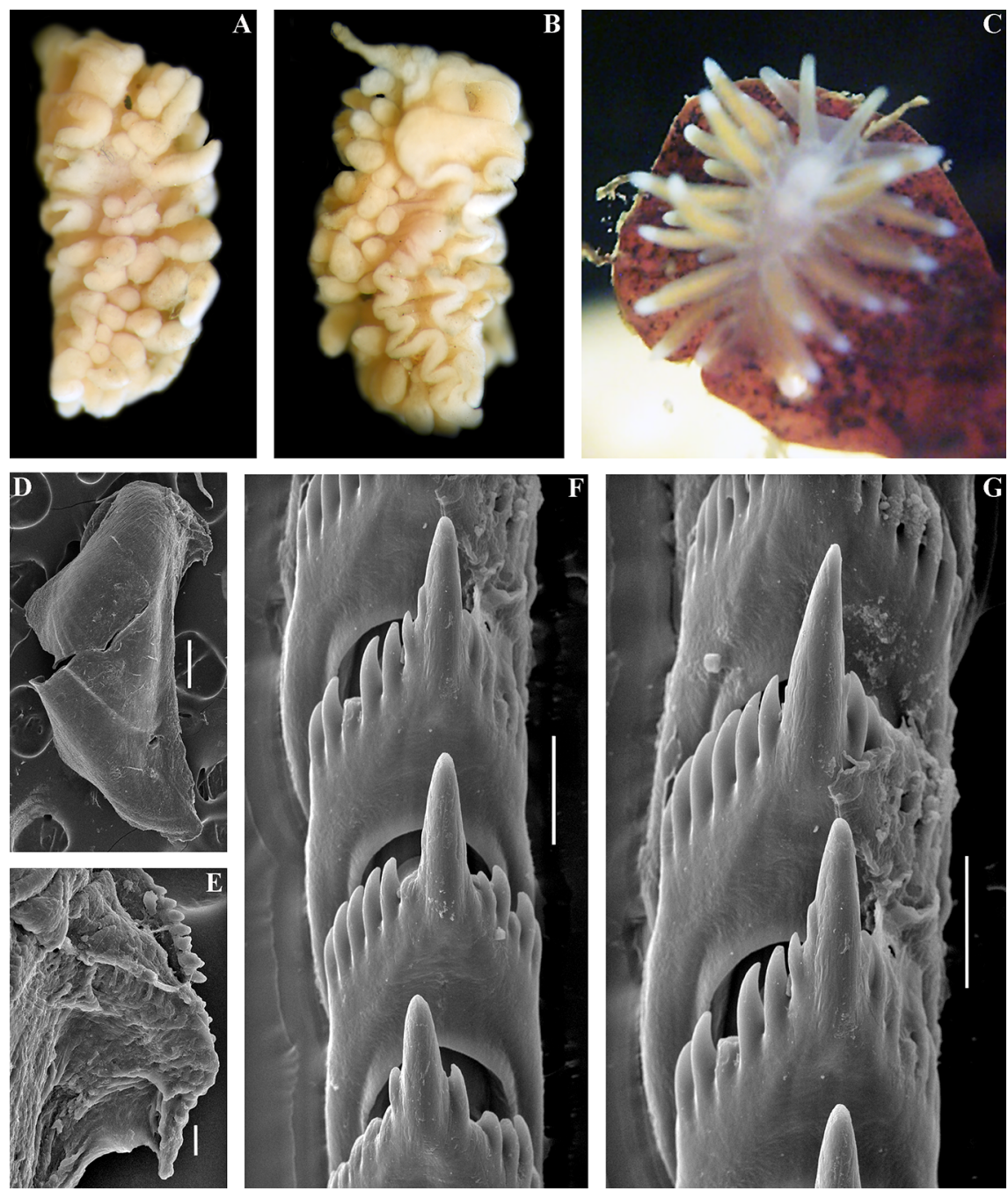

FIGURE 13 Cuthonella orientosiberica sp. nov. A, B, preserved holotype ZMMU Op-184, the East Siberian Sea, $3.5 \mathrm{~mm}$ (preserved length), dorsal and ventral views respectively. C, photograph of a living specimen (juvenile, not collected), the East Siberian Sea, c. 2-3 mm. D, jaw, paratype, zMMU Op-185, the East Siberian Sea (SEM). E, jaw, same, details. F, anterior part of the radula, ZMMU Op-185 (SEM). G, posterior part of the radula, same. Scale bars: D, $200 \mu \mathrm{m}$; E, $20 \mu \mathrm{m}$; F, G, $30 \mu \mathrm{m}$; Photos: A, B, Alexander Martynov, C, courtesy of Sergei Gagaev, D, G, Alexander Martynov.

Rugozerskaya Bay, intertidal, collected by T.A. Korshunova, and A.V. Martynov, 14.06.2009. ZMMU Op-666, 5 spec., $L=$ c. $5 \mathrm{~mm}$ each (preserved), White Sea, Rugozerskaya Bay, collected by A.E. Zhadan, 2009-2010.

Externalmorphology. Body moderately wide. Foot and tail broad. Oral tentacles moderate. Rhinophores similar in size or slightly shorter than oral tentacles, smooth to slightly wrinkled.
Dorsal cerata elongate, thick, arranged in continuous rows. Up to 7 pre-anal unbranched ceratal rows. Anal opening acleioproctic.

Colour (live). Background colour yellowish, sometimes with dispersed orange pigment. Digestive gland diverticula in cerata from dark beige to dark brown. Ceratal tips with peculiar opaque bluish to whitish subapical band or spot, without opaque white pigment. 
Rhinophores yellowish without distinct white pigment at the top (fig. 12A).

Jaws. Jaws broad, yellowish in colour. Masticatory processes of jaws covered with a single row of distinct denticles (fig. 12D, E).

Radula. Radula formula $23 \times$ 0.1.0 (specimen $14 \mathrm{~mm}$ in length). Central tooth elongated with a strongly protracted, pointed non-compressed cusp (fig. 12F, G). Central tooth bears up to 12 lateral denticles. Cusp clearly delineated from the adjacent first lateral denticles.

Reproductive

system.

Diaulic.

Hermaphroditic duct leads to a relatively long, folded, non-swollen ampulla. Vas deferens long, without a distinct prostate. Supplementary gland long, inserts into the vas deferens a considerable distance from the elongated penial sheath. Penis conical, unarmed. Oviduct connects through the insemination duct into the female gland complex. Receptaculum seminis in a distal position, on a long massive stalk, oval (fig. 2oC).

Ecology. Lives on stones and rocks. Intertidal to $5 \mathrm{~m}$ depth. Larvae exhibit direct development without a planktonic stage.

Distribution. Currently known only from the White Sea, possibly it also occurs in the Barents Sea.

Remarks. According to the molecular phylogenetic analysis, Cuthonella hiemalis forms a separate clade sister to the clade containing $C$. soboli, $C$. osyoro, $C$. benedykti sp. nov., $C$. georgstelleri sp. nov., and $C$. ainu sp. nov. (figs 1, 2). The maximum intragroup distance in $C$. hiemalis is $0.31 \%$. The minimum COI intergroup distance of $8.37 \%$ is found between $C$. hiemalis and $C$. osyoro (table 1).

Morphological analysis reveals considerable differences in the denticulation of the central teeth between $C$. hiemalis and the related species $C$. benedykti sp. nov., $C$. denbei sp. nov., C. georgstelleri sp. nov., $C$. osyoro, and C. soboli Martynov, 1992 (figs $7,10,11,14,17)$. Reproduction occurs in the wintertime. Cuthonella hiemalis feeds on the athecate hydroids Clava multicornis (Forsskål, 1775), Sarsia lovenii (M. Sars, 1846), and on the thecate Dynamena pumila (Linnaeus, 1758) (Roginskaya, 1987). For a morphological comparison with other Cuthonella species, see table 2 .

\section{Cuthonella orientosiberica sp. nov.}

(Figs 1, 2, 13, 20D, 21)

ZooBank: http://urn:lsid:zoobank.org:act:106FEoCB-1D9o-4EDC-B649-BB4AEo7932C7

Type material. Holotype. ZMMU Op-184, $L=3.5 \mathrm{~mm}$ length (preserved), East Siberian Sea, $70^{\circ}$ o9.9 $0^{\prime} \mathrm{N}, 161^{\circ} 16.18^{\prime} \mathrm{E}$, depth $9 \mathrm{~m}$, collected by A.Y. Voronkov, o6.og.2004.

Paratypes. ZMMU Op-733, $L=4 \mathrm{~mm}$ length (preserved), East Siberian Sea, $70^{\circ}$ o9.9o' $\mathrm{N}, 161^{\circ} 16.18^{\prime} \mathrm{E}$, depth $9 \mathrm{~m}$, collected by A.Y. Voronkov, o6.o9.2004. ZMMU Op-185, $L=4 \mathrm{~mm}$ length, East Siberian Sea, $69^{\circ} 10.50^{\prime}$ $\mathrm{N}, 169^{\circ} 52.87^{\prime} \mathrm{E}$, depth $15 \mathrm{~m}$, collected by A.Y. Voronkov, 07.09.2004.

Etymology. The name refers to the type locality. Oriento-, Lat. "belonging to the east" and the Siberian Sea.

External morphology. Body moderately wide. Foot and tail broad. Oral tentacles moderate. Rhinophores similar in size to oral tentacles, smooth to slightly wrinkled. Dorsal cerata elongate, thick, arranged in continuous rows. Up to 6 pre-anal unbranched ceratal rows. Anal opening acleioproctic.

Colour (live). Background colour yellowish white. Digestive gland diverticula light brownish to yellowish in juveniles and brownish to dark brown in adults. Ceratal tips whitish. Rhinophores light yellowish with white pigment at the top.

Jaws. Jaws broad, yellowish in colour. Masticatory processes of jaws covered with a single row of denticles (fig. $13 \mathrm{D}, \mathrm{E}$ ). 


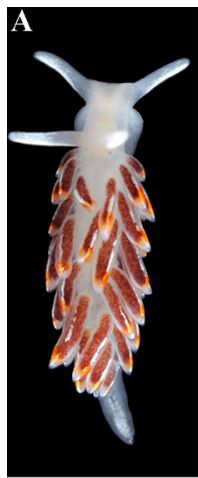

G
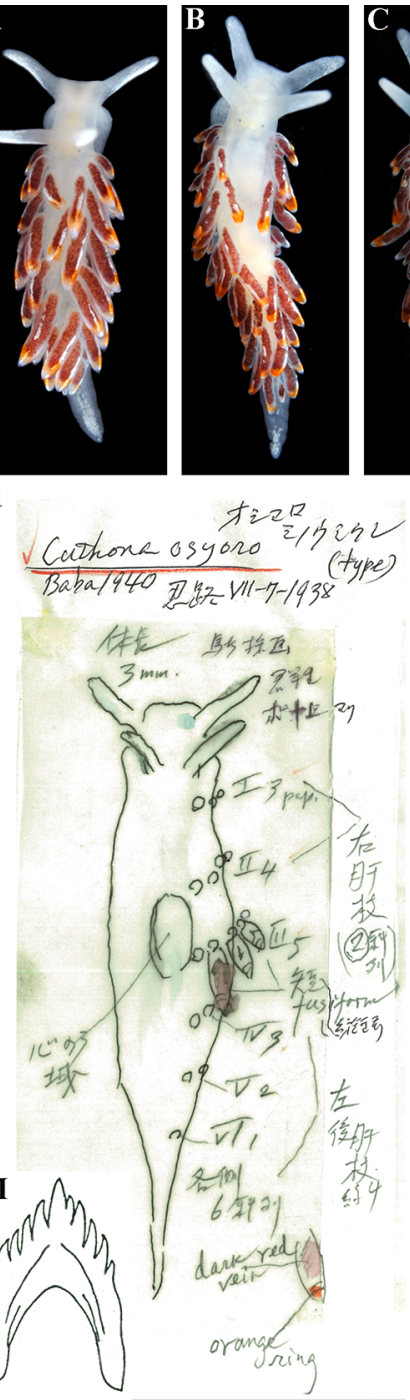
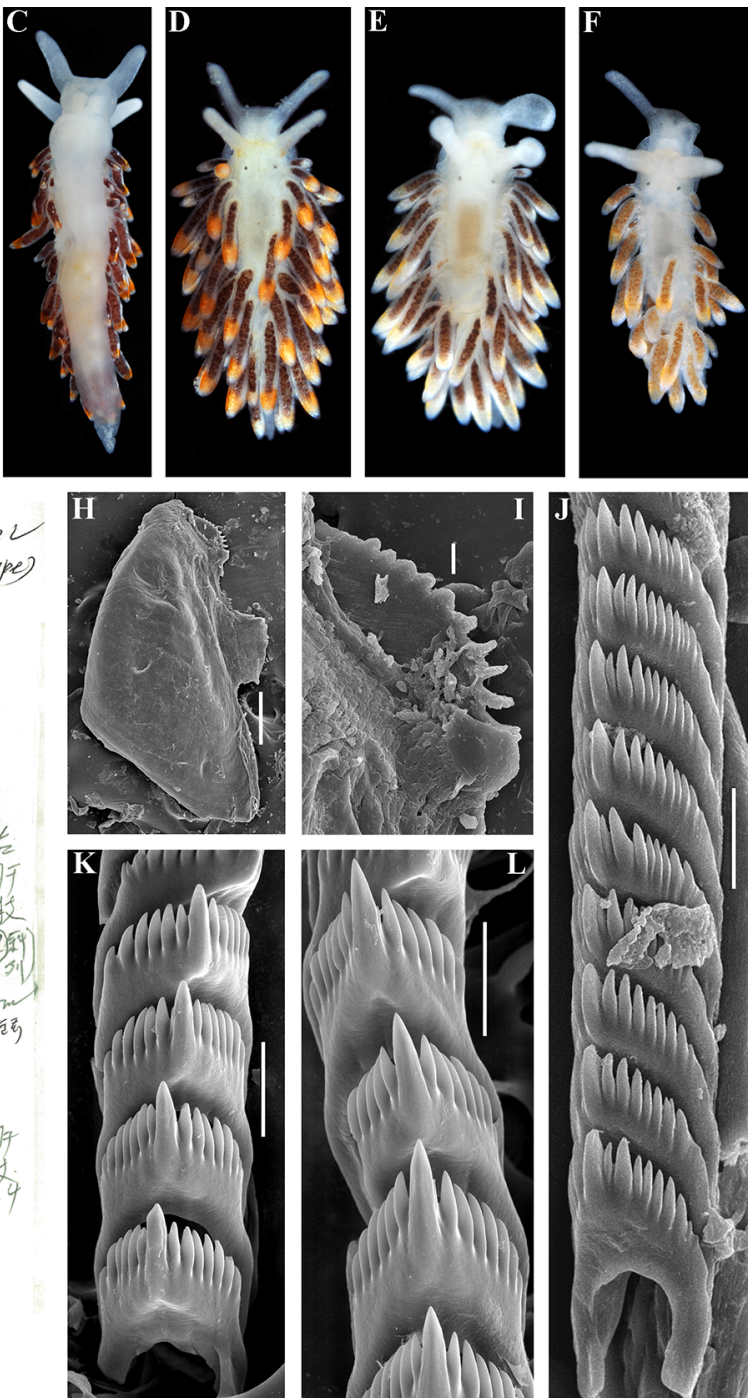

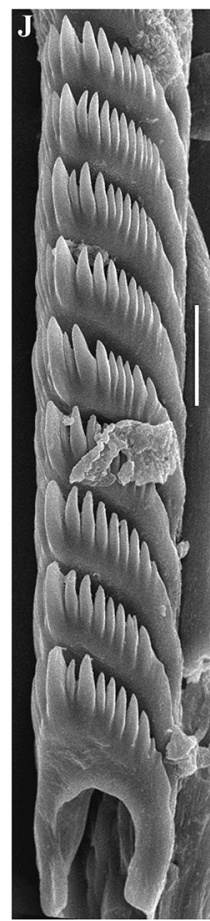

FIGURE 14 Cuthonella osyoro (Baba, 1940). A, living neotype zmmU Op-743, the Sea of Japan, $4 \mathrm{~mm}$ (live length), dorsal view. B, C, living specimen zmmu Op-613, the Sea of Japan, $9 \mathrm{~mm}$ (live length), dorsal and ventral views respectively. D, living specimen zMMU Op-6o7, the Sea of Japan, $4 \mathrm{~mm}$ (preserved length), dorsal view. E, living specimen zMmU Op-524, the Sea of Japan, $3 \mathrm{~mm}$ (preserved length), dorsal view. F, living specimen ZMMU Op-6o6, the Sea of Japan, $3 \mathrm{~mm}$ (preserved length), dorsal view. G, original drawings of external view by Kikutaro Baba, essentially similar to those used for the original description of "Cuthona" osyoro Baba, 1940. H, jaw, zMmU Op-6o7 (SEM). I, same, details. J, anterior and middle parts of the radula, zMMU Op-607 (SEM). K. anterior part of the radula, zMMU Op-6o4 (SEM). L, posterior part of the radula, ZMMU Op-604 (SEM). M, original drawings of radular teeth of "Cuthona" osyoro by Kikutaro Baba. Scale bars: G, $100 \mu \mathrm{m}$; H, J, K, $10 \mu \mathrm{m}$; I, $20 \mu \mathrm{m}$; Photos: A-F, Tatiana Korshunova, G, M, drawings by Kikutaro Baba courtesy of Yoshiaki Hirano, So Ishida and Sho Kashio, H-L, Alexander Martynov.

Radula. Radula formula $28 \times$ 0.1.o (specimen $4 \mathrm{~mm}$ in length). Central tooth elongated with a strongly protracted, pointed non-compressed cusp (fig. $13 \mathrm{~F}, \mathrm{G}$ ). Central tooth bears up to 9 lateral denticles. Cusp clearly delineated from the adjacent first lateral denticles. 
Reproductive system. Diaulic. Hermaphroditic duct leads to a relatively long, folded, swollen ampulla. Vas deferens moderately long, without a distinct prostate. Supplementary gland long, inserts into the vas deferens a considerable distance from the elongated penial sheath. Penis conical, unarmed. Oviduct connects through the insemination duct into the female gland complex. Receptaculum seminis in a distal position, on a short stalk, oval (fig. 2oD).

Ecology. Lives on stones and rocks at depths of c. 9-15 m.

Distribution. Arctic Seas - East Siberian Sea, Laptev Sea, possibly also Chukchi Sea.

Remarks. According to the morphological data, Cuthonella orientosiberica sp. nov. is similar to C. hiemalis (Roginskaya, 1987) and C. soboli Martynov, 1992. However, there are differences in the denticulation of the central teeth between $C$. orientosiberica sp. nov. and the species $C$. hiemalis and $C$. soboli (figs 12, 17). The available material was not suitable for molecular study, despite several attempts to extract DNA. For a morphological comparison with other Cuthonella species, see table 2.

\section{Cuthonella osyoro (Baba, 1940)}

(Figs 1, 2, 14, 20E, 21)

Cuthona osyoro Baba, 1940: 108, fig. 8

Cuthonella osyoro (Baba, 1940) - Martynov, 2006b: 29o; Martynov, Korshunova, 2011, partim, only the fig. on page 198 .

Type material. Holotype, lost. Neotype ZMMU Op-743, $L=4$ mm length (live), the Sea of Japan, Spokoinaya Bay, 3-5 m depth, brown algae, stones, collected by T.A. Korshunova and A.V. Martynov, 25.09.2014.

Other material. zMMU Op-734, $L=c$. $15 \mathrm{~mm}$ length (preserved, c. $25 \mathrm{~mm}$ live), the Sea of Japan, Vostok Bay, 0.2-0.4 m, stones, collected by A.V. Martynov, 18.o2.1990. ZMMU Op-6o6, 1 spec., $L=3 \mathrm{~mm}$ length (preserved), the Sea of Japan, Spaseniya Bay, 0.3-0.7 m, stones, collected by T.A. Korshunova and A.V. Martynov, 16.o9.2014. ZMMU Op-6o7, 1 spec., $L=4 \mathrm{~mm}$ length (preserved), the Sea of Japan, Spaseniya Bay, 0.3-0.7 m, stones, collected by T.A. Korshunova and A.V. Martynov, 16.o9.2014. ZMMU Op-524, 1 spec., $L=3 \mathrm{~mm}$ length (preserved), the Sea of Japan, Gornostay Bay, 0.5-0.7 m, stones, collected by T.A. Korshunova and A.V. Martynov, 18.o9.2014. ZMMU Op-6o4, 1 spec., $L=4 \mathrm{~mm}$ length (live), the Sea of Japan, Spokoinaya Bay, 3-5 m, brown algae, stones, collected by T.A. Korshunova and A.V. Martynov, 25.09.2014. ZMMU Op-613, 1 spec., $L=9 \mathrm{~mm}$ length (live), the Sea of Japan, Spokoinaya Bay, 3-5 m, brown algae, stones, collected by T.A. Korshunova and A.V. Martynov, 25.09.2014.

External morphology. Body moderately wide. Foot and tail broad. Oral tentacles moderate. Rhinophores similar in size to oral tentacles, smooth to slightly wrinkled. Dorsal papillae elongate, thick, arranged in continuous rows. Up to 6 pre-anal unbranched ceratal rows. Anal opening acleioproctic.

Colour (live). Background colour translucent whitish, sometimes slightly yellowish. Digestive gland diverticula brownish to dark red or violet. Ceratal tips with variously expressed red or orange band or spot. On cerata white streaks or dots may be present. Rhinophores semi-transparent, sometimes with white pigment at the top (fig. 14A-G).

Jaws. Jaws broad, yellowish in colour. Masticatory processes of jaws covered with a single row of distinct denticles (fig. $14 \mathrm{H}, \mathrm{I}$ ).

Radula. Radula formula $26 \times 0.1 .0$ (specimen $9 \mathrm{~mm}$ in length), $24 \times$ 0.1.o (specimen $8 \mathrm{~mm}$ in length). Central tooth elongated with a strongly protracted, pointed non-compressed cusp (fig. $14 \mathrm{~J}-\mathrm{M}$ ). Central tooth bears up to 11 lateral denticles. Cusp clearly delineated from the adjacent first lateral denticles.

Reproductive system. Diaulic. Hermaphroditic duct leads to a relatively short, 

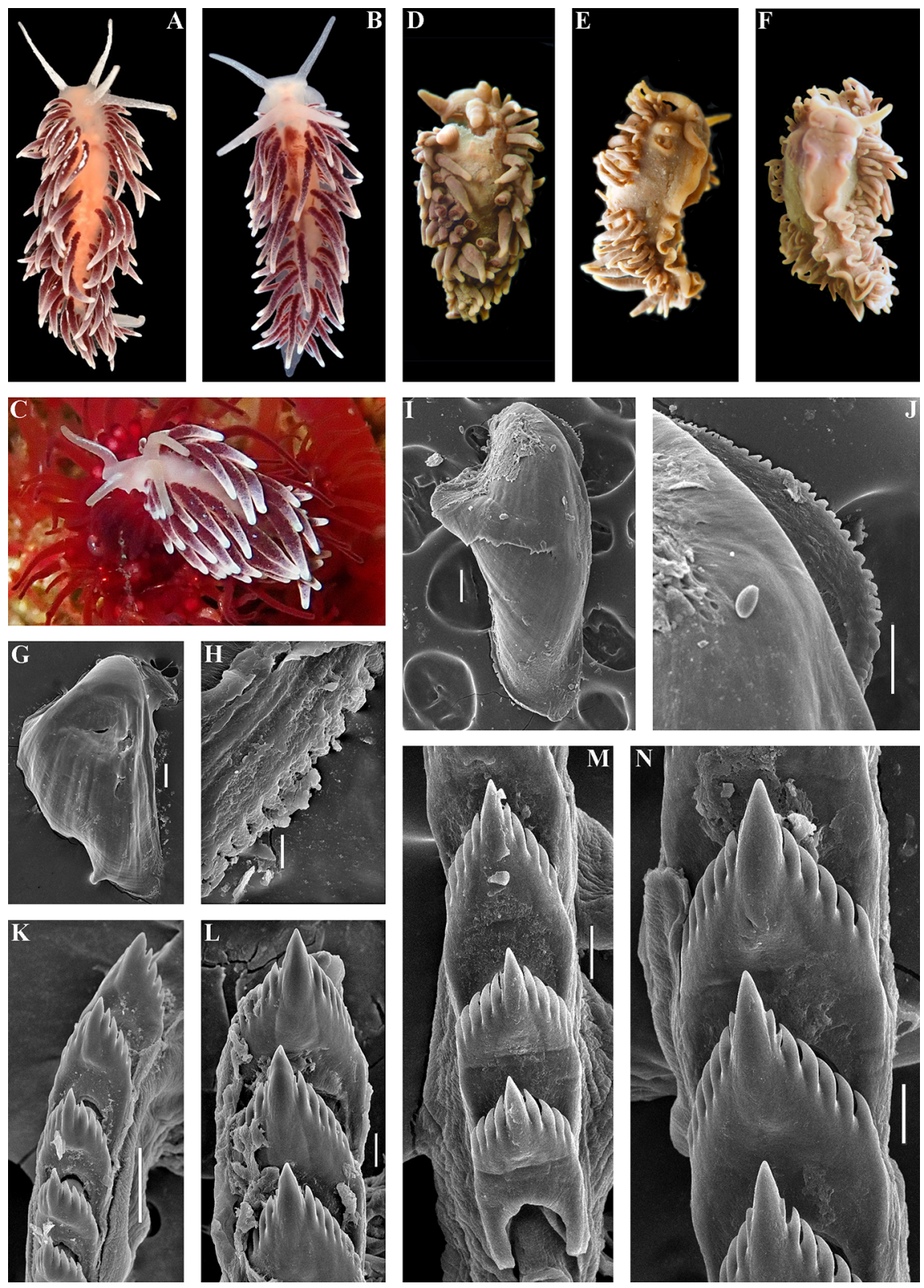

FIGURE 15 Cuthonella punicea (Millen, 1986). A, living specimen, British Columbia, Plumper Islands, $21 \mathrm{~mm}$ (live length), dorsal view. B, living specimen, British Columbia, Plumper Islands, 13 mm (live length), dorsal view. C, living specimen on the hydroid Zyzzyzus rubusidaeus, food object (specimen was not collected). D-F, topotype specimen collected and identified by Sandra Millen, British Columbia, Plumper Islands, ZMMU Op-735, 7 mm (preserved length), dorsal, lateral and ventral views respectively. G, jaw, from specimen 15 mm (SEM). H, jaw, details, same. I, jaw, ZMMU Op-735 (SEM). $\mathrm{J}$, jaw, details, same. K, anterior part of the radula from specimen $15 \mathrm{~mm}(\mathrm{SEM}) . \mathrm{L}$, posterior part of the radula, same (SEM). M, anterior part of the radula, ZMMU Op-735 (SEM). N, posterior part of the radula, same. Scale bars: G, I, $100 \mu \mathrm{m}$; H, $10 \mu \mathrm{m}$; J, K, $50 \mu \mathrm{m}$; L-N, $20 \mu \mathrm{m}$; Photos: A, B, Karin Fletcher, C, Neil McDaniel, D-N, Alexander Martynov. 
swollen, convoluted ampulla. Vas deferens moderately long, without a distinct prostate. Supplementary gland long, inserts into the vas deferens a considerable distance from the elongated penial sheath. Penis conical, unarmed. Oviduct connects through the insemination duct into the female gland complex. Receptaculum seminis in a distal position, on a short stalk, rather rounded (fig. 20E).

Ecology. Lives on stones and rocks. Intertidal to $20 \mathrm{~m}$ depth.

Distribution. The Northern part of the Sea of Japan, Hokkaido, possibly also the Southern Kuril Islands.

Remarks. According to the molecular phylogenetic analysis, Cuthonella osyoro forms a sister clade with $C$. soboli and is also a member of a larger clade which includes $C$. hiemalis, C. benedykti sp. nov., C. georgstelleri sp. nov., and $C$. ainu sp. nov. (figs. 1, 2). The maximum intragroup distance in $C$. osyoro is $1.15 \%$. The minimum COI intergroup distance of $2.89 \%$ is found between $C$. osyoro and $C$. soboli (table 1). Cuthonella osyoro differs externally from the closely related species $C$. soboli (fig. 17) in always having red or orange spots or rings on the ceratal tips. This variable-sized reddish or orange spot at the ceratal tips is present in all specimens of $C$. osyoro that we have observed, even in small juveniles, which was confirmed in the present study (fig. 14E, F). However, prior to this study $C$. osyoro specimens were sometimes mistaken for $C$. soboli because the pale orange ceratal spot on juvenile $C$. osyoro specimens that were sequenced (fig. $14 \mathrm{D}$, for example) was inadvertently overlooked (Korshunova et al., 2017b, 2018a).

In the original description, Baba (1940) described a juvenile specimen from Hokkaido which is identifiable by the presence of red markings on the ceratal apices and patterns of the radula. In the present study, we specially visited the archive of Baba's material in Osaka and have presented a copy of the original painting by Baba (fig. $14 \mathrm{G}, \mathrm{M}$ ) to confirm the identity of this species. In the summertime in the intertidal and upper subtidal zones of the Sea of Japan juveniles of $C$. osyoro are quite common, and therefore Baba (1940) described a juvenile of exactly this species from a neighbouring location at the Hokkaido coast of the Sea of Japan. In order to avoid confusion between two sympatric sister species $C$. soboli and C. osyoro, neotype is selected here for $C$. osyoro (fig. 14A). The neotype is essentially similar in colouration and size to the first description of $C$. osyoro and was collected in the Sea of Japan across from the type locality in Hokkaido. The food objects of $C$. osyoro possibly include athecate hydroids. For a morphological comparison with other Cuthonella species, see table 2.

\section{Cuthonella punicea (Millen, 1986)}

(Figs 1, 2, 15, 20F, 21)

Cuthona punicea Millen, 1986: 1356-1358, figs 1-7.

Cuthonella punicea (Millen, 1986) Martynov, 1992: 23.

Non "Tenellia" pustulata sensu Cella et al., 2016 (= Zelentia nepunicea, see discussion in Korshunova et al., 2017a, 2018b; misidentification of Zelentia nepunicea with Cuthonella punicea in Cella et al., 2016).

Type material. Holotype. CASIZ o6o327, NE Pacific, Canada, British Columbia, Plumper Islands, $50^{\circ} 36^{\prime} \mathrm{N}, 126^{\circ} 49^{\prime} \mathrm{W}, 13 \mathrm{~m}$ depth, rocks, collected by S.V. Millen, o6.05.1985.

Topotypes. ZMMU Op-735, 3 specimens, $L=7 \mathrm{~mm}, 7.2 \mathrm{~mm}$, and $4 \mathrm{~mm}$ length (preserved), NE Pacific, Canada, British Columbia, Plumper Islands, $50^{\circ} 36^{\prime} \mathrm{N}, 126^{\circ} 49^{\prime} \mathrm{W}, 2 \mathrm{O}-22 \mathrm{~m}$, rocks, collected by S.V. Millen, 07.05.1983. KM 765, 1 specimen, $L=21 \mathrm{~mm}$, NE Pacific, Canada, British Columbia, Plumper Islands, 8.2-17.7 $\mathrm{m}$, collected by Karin Fletcher, 12.04.2019. KM 766, $L=15 \mathrm{~mm}$, NE Pacific, Canada, British Columbia, Plumper Islands, 8.2-17.7 m, collected by Karin Fletcher, 12.04.2019. 

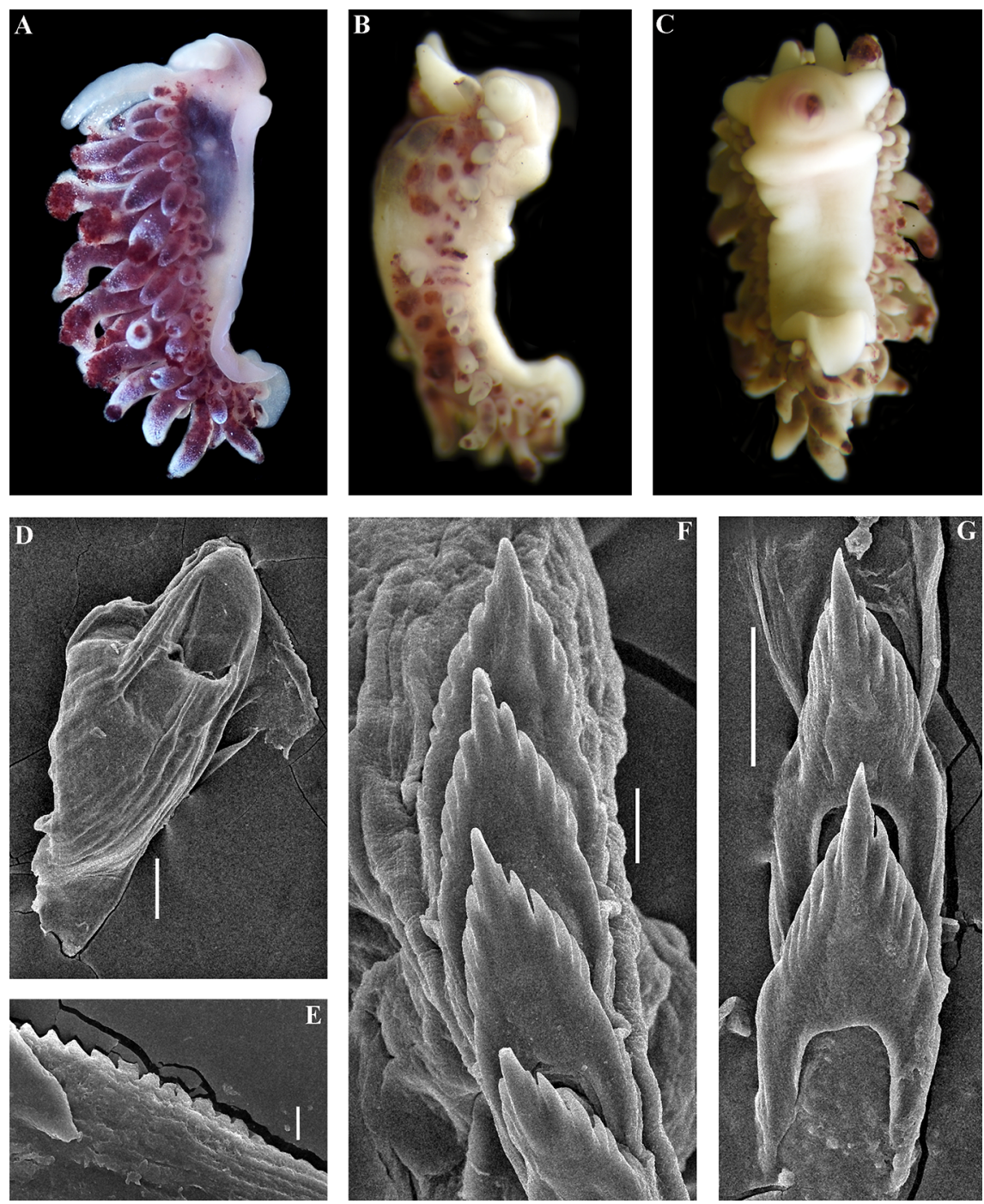

FIGURE 16 Cuthonella sandrae sp. nov. A, living holotype, Matua Island, zMmU Op-671, 4 mm (preserved length), lateral view. B, C, same, preserved holotype, lateral and ventral views respectively. D, jaw, holotype (SEM). E, jaw, details, same. F, anterior part of the radula, holotype (SEM). G, posterior part of the radula, same. Scale bars: D, $100 \mu \mathrm{m}$; E, $10 \mu \mathrm{m}$; F, $20 \mu \mathrm{m}$; G, 50 $\mu \mathrm{m}$; Photos: A, Nadezhda Sanamyan, B-G, Alexander Martynov.

External morphology. Body wider in front than behind. Foot and tail broad. Oral tentacles moderate. Rhinophores smooth and similar in size or slightly longer than the oral tentacles. Dorsal papillae elongate, arranged in continuous rows. Up to 8 pre-anal partially branched ceratal rows. Anal opening cleioproctic.

Colour (live). Background colour pinkishyellowish white to pale peach. Digestive gland diverticula from purple to dark winered,(pomegranate colour). Cerata with white spots or streaks on surface. Cerata with dispersed white tips. Rhinophores and oral tentacles semi-transparent to light yellowish and often frosted with varying amounts of white pigment for almost the entire length, or the pigment can form a line (fig. $15 \mathrm{~A}-\mathrm{C}$ ). 
Jaws. Jaws broad, yellowish in colour. Masticatory processes of jaws covered with a single row of distinct denticles (fig. $15 \mathrm{G}-\mathrm{J}$ ).

Radula. Radula formula $12 \times$ 0.1.o (specimen $7 \mathrm{~mm}$ in length), c. $18 \times$ 0.1.o (spec. $15 \mathrm{~mm}$ in length). Central tooth elongated with a strongly protracted, pointed non-compressed cusp (fig. $15 \mathrm{~K}-\mathrm{N}$ ). Central tooth bears up to 7 lateral denticles. Cusp clearly delineated from the adjacent first lateral denticles.

Reproductive system. Diaulic. Hermaphroditic duct leads to relatively short, straight, swollen ampulla. Vas deferens long, without a distinct prostate. Supplementary gland long, inserts into the vas deferens a considerable distance from the elongated penial sheath. Penis conical, narrow, unarmed. Oviduct connects through the insemination duct into the female gland complex. Tubular receptaculum seminis in a distal position, without a distinct reservoir (fig. 20F).

Ecology. Lives on soft bottoms with stones at depths of $8-33 \mathrm{~m}$, on or near its hydroid prey, the large athecate species Zyzzyzus rubusidaeus Brinckmann-Voss \& Calder, 2013 (Millen, 1986; Brinckmann-Voss \& Calder, 2013). Eggs hatch after 14-15 days as planktotrophic veligers.

Distribution. Northeast Pacific, so far only known from the Plumper Island group located on the northern end of Vancouver Island, British Columbia.

Remarks. In the present study, molecular data from recently collected Cuthonella punicea from the exact type locality of the Plumper Islands (Canada, British Columbia) is presented for the first time (figs 1, 2, 21). According to that molecular phylogenetic data, the species originally described by Millen (1986) as "Cuthona" belongs to the same subclade with the type species of Cuthonella, C. abyssicola, and to a larger clade with all other Cuthonella (figs 1, 2). We also examined topotypes originally collected by
Sandra Millen in 1983 (fig. 15D-F, I, J, M, N), and confirm their essential similarity with the recent specimens collected from the type locality (fig. 15A-C).

The profound morphological differences between this cuthonellid, Cuthonella punicea, and the trinchesiid Zelentia nepunicea have previouslybeen highlighted (see Korshunova et al., 2017a, 2018b). Those differences combined with the examination of original topotypes and fresh material for molecular analysis in this study provide irrefutable evidence that the synonymy of those two species proposed by Cella et al. (2016) is not valid.

A cuthonellid from the NW Pacific (Matua Island), Cuthonella sandrae sp. nov., with a similar purple colour is a sister species to $C$. punicea (figs 1, 2), but differs significantly according to genetic distances, molecular phylogenetic analysis, external patterns of the digestive gland branches and the shape of the radular teeth (figs 15, 16).

Cuthonella punicea forms the clade sister to the clade containing Cuthonella sandrae sp. nov. and C. abyssicola kryos subsp. nov. (fig. 1). The maximum intragroup distance in $C$. punicea is $0.76 \%$. The minimum coI intergroup distance of $6.85 \%$ is found between C. punicea and $C$. sandrae sp. nov (table 1 ). For a morphological comparison with other Cuthonella species, see table 2.

\section{Cuthonella sandrae sp. nov.}

(Figs 1, 2, 16, 21)

ZooBank: http://urn:lsid:zoobank.org:act:Fo4A4DCF-8A29-45BA-88B7-9749DA6E4C72

Type material. Holotype. ZMMU Op-671, 1 spec., $L=4 \mathrm{~mm}$ length (preserved), Pacific Ocean, Middle Kuril Islands, Matua Island, Klyuv Cape, $14 \mathrm{~m}$ depth, collected by N.P. Sanamyan, 20.08.2017.

Etymology. Named in honour of Sandra Violet Millen, a prominent nudibranch researcher of North Pacific nudibranch 

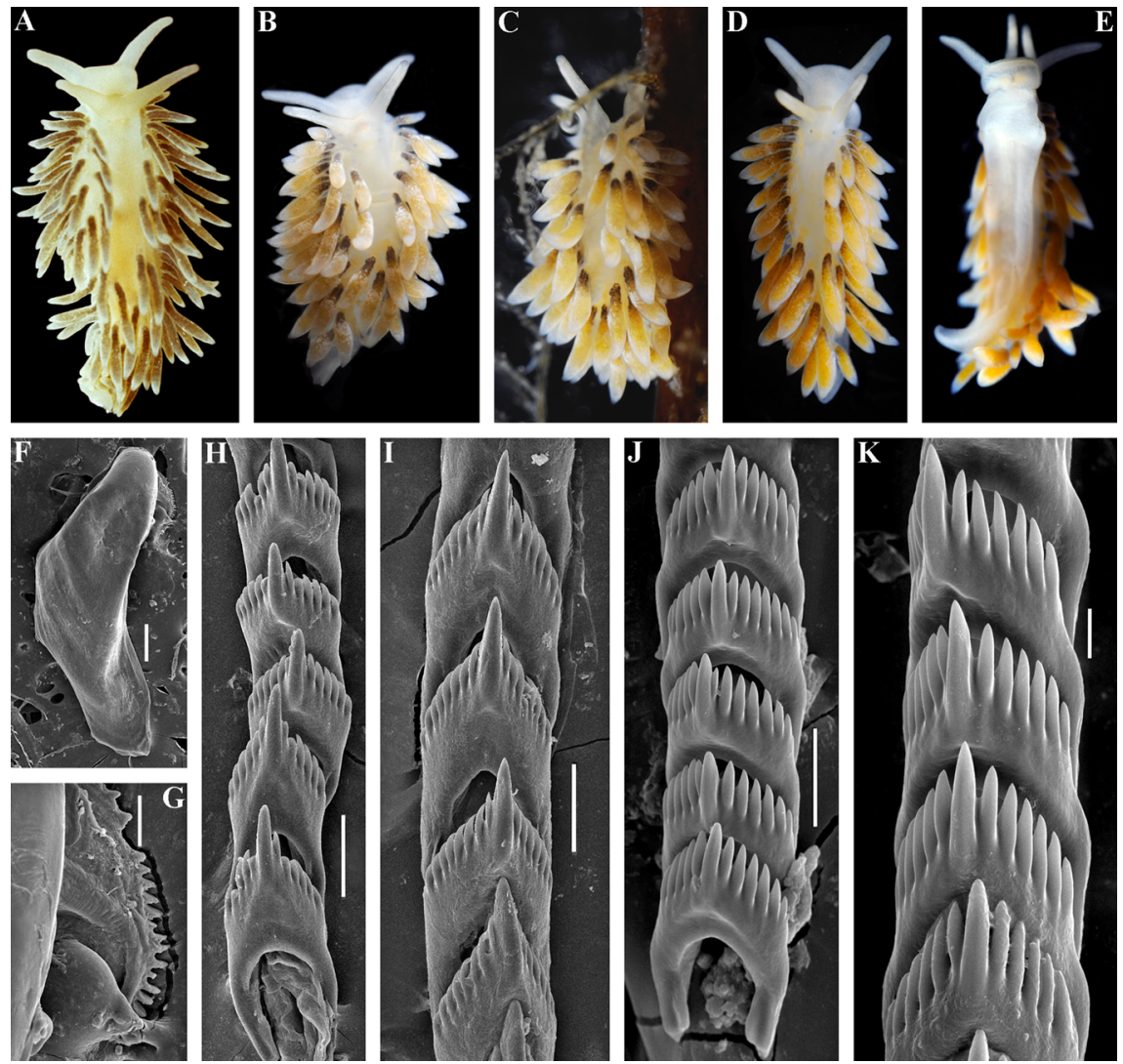

FIGURE 17

Cuthonella soboli Martynov, 1992. A, living holotype zMMU Op-736 (adult), the Sea of Japan, Sobol Bay, c. $30 \mathrm{~mm}$ (live length) dorsal view. B, living specimen zMMU Op-6o5, the Sea of Japan, Spokoinaya Bay, $8 \mathrm{~mm}$, semi-juvenile (live length), dorsal view. C, same specimen on substrate. D, E, second living specimen, from the same location and lot, dorsal and ventral views respectively. F, jaw, ZMMU Op-737 (SEM). G, jaw, details, same. H, anterior part of radula, ZMMU Op-737. I, posterior part of the radula, same. J, anterior part of radula, ZMMU Op-6o5 (SEM). K, posterior part of radula, same. Scale bars: F, 200

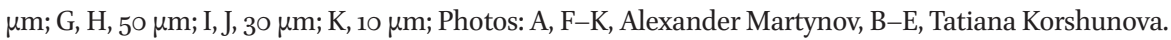

molluscs. Most remarkably, in the present study we discovered a new species from the Kuril Islands which is a sister species to Cuthonella punicea (Millen, 1986) previously described by Sandra Millen from British Columbia, and which is similar to the new species in its reddish-purple colouration (fig. $15 \mathrm{~A}-\mathrm{C}$ ) but with substantial genetic and radular differences.

External morphology. Body moderately wide. Foot and tail broad. Oral tentacles moderate. Rhinophores similar in size to oral tentacles, smooth to slightly wrinkled. Dorsal papillae elongate, thick, arranged in continuous rows. Up to $c$. 7 pre-anal branched ceratal rows. Anal opening cleioproctic.

Colour (live). Background colour semitransparent white with purple-bluish areas. Digestive gland diverticula in the cerata violet-purple. Ceratal tips with dispersed white pigment and bluish hue. Rhinophores semi-transparent with sparse white pigment at the top (fig. 16A).

Jaws. Jaws broad, yellowish in colour. Masticatory processes of jaws covered with a single row of distinct denticles (fig. 16D, E).

Radula. Radula formula $12 \times 0.1 .0$ (specimen $4 \mathrm{~mm}$ in length). Central tooth elongated 
with a strongly protracted, pointed noncompressed cusp (fig. 16F, G). Central tooth bears up to 8 lateral denticles. Cusp relatively unclearly delineated from the adjacent first lateral denticles.

Reproductive system is underdeveloped in the holotype and not suitable for a detailed study.

Ecology. Lives on soft bottoms with stones at $14 \mathrm{~m}$ depth.

Distribution. Matua Island, Middle Kuril Islands.

Remarks. According to the molecular phylogenetic analysis, Cuthonella sandrae sp. nov. is closest to $C$. punicea (Millen, 1986) and C. abyssicola kryos (figs 1, 2). The minimum COI intergroup distance of $6.85 \%$ is found between $C$. sandrae sp. nov. and $C$. punicea (Table 1). Morphological analysis and molecular analysis reveal considerable differences between $C$. sandrae sp. nov. and any other species of the genus Cuthonella, including the externally similar $C$. punicea (fig. 15). Particularly in $C$. sandrae sp. nov. a continuous series of small branches of the digestive gland forms between the anterior and posterior parts of the digestive gland even at a relatively small size. In contrast, C. punicea has a rather linear, only weakly branched digestive gland which does not form a continuous row in between the anterior and posterior parts of the digestive gland even at a considerably larger size. The radular patterns between $C$. punicea and $C$. sandrae sp. nov. are also considerably different (figs $15 \mathrm{M}, \mathrm{N}$ and 16F, G). For a morphological comparison with other Cuthonella species, see table 2.

\section{Cuthonella soboli Martynov, 1992}

(Figs 1, 2, 17, 20G, 21)

Cuthonella soboli Martynov, 1992: 18-23, figs 1-3; Martynov, 20o6b: 29o; Martynov, 2015b: 8o; Martynov \& Korshunova, 2011: 197-198, fig. on page 197, excluding the figure on page 198 (C. osyoro).

Type material. Holotype. ZMMU Op-736, $L=c .30 \mathrm{~mm}$ (live), The Sea of Japan, Sobol Bay, intertidal, stones, 03.03.1992. Paratype. ZMMU Op-737, $L=15 \mathrm{~mm}$ length (preserved), The Sea of Japan, Sobol Bay, 0.2-0.7 m depth, stones, collected by A.V. Martynov, 05.02.1992.

Other material: ZMMU Op-6o5, 2 spec., $L=8 \mathrm{~mm}$ length (live), The Sea of Japan, Spokoinaya Bay, 3-5 $\mathrm{m}$ depth, brown algae, stones, collected by T.A. Korshunova and A.V. Martynov, 25.09.2014.

External morphology Body moderately wide. Foot and tail broad. Oral tentacles moderate. Rhinophores similar in size, or slightly longer than oral tentacles, smooth to slightly wrinkled. Dorsal cerata elongate, thick, arranged in continuous rows. Up to 6 pre-anal ceratal rows. Anal opening acleioproctic.

Colour (live). Background colour yellowish white. Digestive gland diverticula in cerata from light brownish and sandy to tobacco- and dark-brown. Basal parts of cerata commonly darker. White spots or streaks on the ceratal external surface. Ceratal tips colourless or with dispersed white pigment. Rhinophores semi-transparent to light yellowish and orange ochre with indistinct to dispersed white pigment on the top (fig. $17 \mathrm{~A}-\mathrm{E}$ ).

Jaws. Jaws broad, yellowish in colour. Masticatory processes of jaws covered with a single row of distinct denticles (fig. $17 \mathrm{~F}, \mathrm{G}$ ).

Radula. Radula formula $28 \times 0.1 .0$ (specimen $15 \mathrm{~mm}$ in length), $24 \times$ 0.1.o (specimen $8 \mathrm{~mm}$ in length). Central tooth elongated with a strongly protracted, pointed non-compressed cusp (fig. ${ }_{17} \mathrm{H}-\mathrm{K}$ ). Central tooth bears up to 10 lateral denticles. Cusp clearly delineated from the adjacent first lateral denticles.

Reproductive system. Diaulic. Hermaphroditic duct leads to a moderately long, swollen ampulla. Vas deferens 

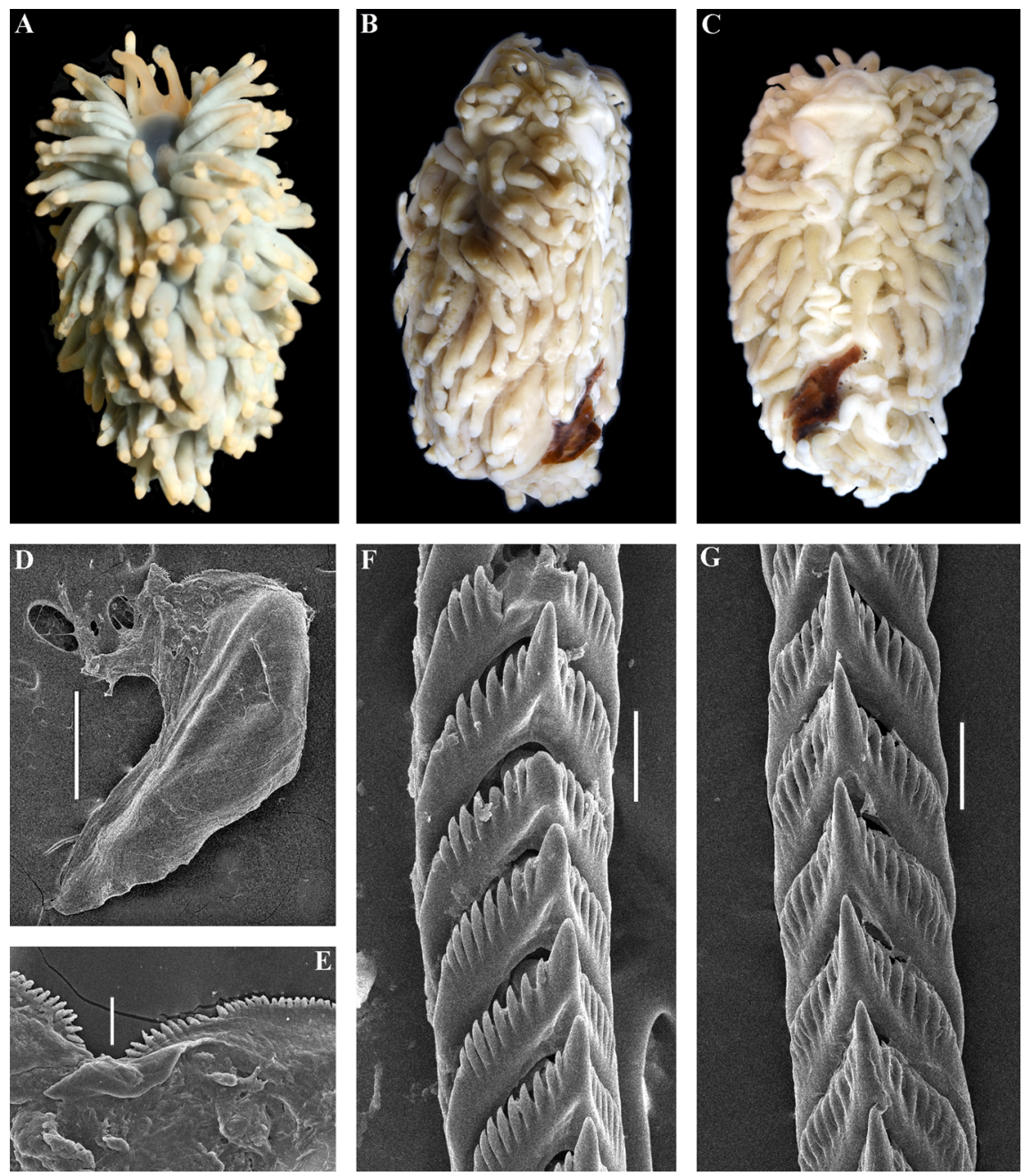

FIGURE 18 Cuthonella vasentsovichi sp. nov. A, living holotype ZMmU Op-738, Matua Island, $21 \mathrm{~mm}$ (preserved length), dorsal view. B, C, preserved holotype, lateral and ventral views respectively. D, jaw, paratype zMMU Op-739, Matua Island (SEM). E, jaw, details, same. F, anterior part of the radula, paratype (SEM). G, posterior part of the radula, same. Scale bars: D, $500 \mu \mathrm{m} ; \mathrm{E}, \mathrm{F}, \mathrm{G}, 50 \mu \mathrm{m}$; Photos: A, Nadezhda Sanamyan, B- G, Alexander Martynov.

moderately long, without a distinct prostate. Supplementary gland long, inserts into the vas deferens a considerable distance from the elongated penial sheath. Penis conical, unarmed. Oviduct connects through the insemination duct into the female gland complex. Receptaculum seminis in a distal position, on a moderately long stalk, pearshaped (fig. 2OG).
Ecology. Stones, rocks. Intertidal to c. $10 \mathrm{~m}$ depth. Veligers exhibit direct development or a shortened planktonic stage.

Distribution. The northern part of the Sea of Japan, possibly also the Southern Kuril Islands and Hokkaido.

Remarks. According to the molecular phylogenetic analysis, Cuthonella soboli Martynov, 1992 forms a separate clade sister 
to the $C$. osyoro clade (figs 1,2 ). The minimum COI intergroup distance of $2.89 \%$ is found between $C$. soboli and $C$. osyoro (Table 1). Externally $C$. soboli differs from the closely related species $C$. osyoro by the absence of any reddish or orange spots on the cerata (fig. 17). Morphological analysis reveals considerable differences in the denticulation of the central teeth between $C$. hiemalis, $C$. osyoro, C. soboli, and the type species of the genus Cuthonella, C. abyssicola s.l. (figs 4, 5, 12, 14, 17). Reproduction occurs in the wintertime. The food objects of $C$. soboli possibly include athecate hydroids (Martynov \& Korshunova, 2011). For a morphological comparison with other Cuthonella species, see table 2.

\section{Cuthonellavasentsovichi sp. nov.}

(Figs 1, 2, 18, 20H, 21)

ZooBank:

http://urn:lsid:zoobank.

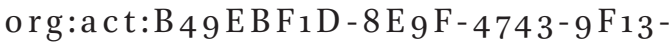
86oo63D7FA9C

Type material. Holotype. ZMMU Op-738, $L=21 \mathrm{~mm}$ length (preserved), Pacific Ocean, Middle Kuril Islands, Matua Island, Klyuv Cape, $14 \mathrm{~m}$, collected by N.P. Sanamyan, 20.08.2017.

Paratype. zMMU Op-739, $L=15 \mathrm{~mm}$ length (preserved), Pacific Ocean, Middle Kuril Islands, Matua Island, Klyuv Cape, 14 m, collected by N.P. Sanamyan, 20.08.2017.

Etymology. Named in honour of Vladislav Konstantinovich Vasentsovich (1898-1961). He was a Division Commander in the Soviet Far East before wWII and was repressed during Stalin's Great Purge, imprisoned for 15 years and freed only a few years before his death (Milbakh, 2003). Vladislav Vasentsovich is a relative of one of the authors of this article (AM). The name was also chosen because the Kuril Islands (type locality of the new species) belongs to the Russian Far East region and for the additional cultural intersection with Benedykt Dybowski, who like Vladislav Vasentsovich, was of a Polish origin and was also repressed earlier in the tsar's Russian Empire.

External morphology. Body wide. Foot and tail broad. Oral tentacles moderate. Rhinophores similar in size to oral tentacles, smooth to slightly wrinkled. Dorsal papillae numerous, elongate, thick, arranged in continuous rows. Up to 10 (or more) pre-anal branched and unbranched ceratal rows. Anal opening cleioproctic.

Colour (live). Background colour greyish. Digestive gland diverticula in cerata greyish to light greenish. Ceratal tips yellowish. Rhinophores dark yellowish, without distinct white pigment at the top (fig. 18A).

Jaws. Jaws moderately broad, yellowish in colour. Masticatory processes of jaws covered with a single row of denticles (fig. 18D, E).

Radula. Radula formula $40 \times$ 0.1.0 (specimen $15 \mathrm{~mm}$ in length). Central tooth elongated with a strongly protracted, pointed non-compressed cusp (fig. 18F, G). Central tooth bears up to 9 lateral denticles. Cusp clearly delineated from the adjacent first lateral denticles.

Reproductive system. Diaulic. Hermaphroditic duct leads to a relatively short, partially swollen, convoluted ampulla. Vas deferens moderate in length, without a distinct prostate. Supplementary gland relatively short, inserts into the vas deferens a considerable distance from the elongated penial sheath. Penis conical, unarmed. Oviduct connects through the insemination duct into the female gland complex. Receptaculum seminis in a distal position, on a short stalk, oval (fig. 20H).

at $14 \mathrm{~m}$ depth.

Distribution. Matua Island, Middle Kuril Islands.

Remarks. The maximum intragroup distance in $C$. vasentsovichi is $0.15 \%$. The minimum COI intergroup distance of $9.28 \%$ is found between $C$. vasentsovichi sp. nov. sp. nov. and $C$. concinna concinna (table 1 ). 

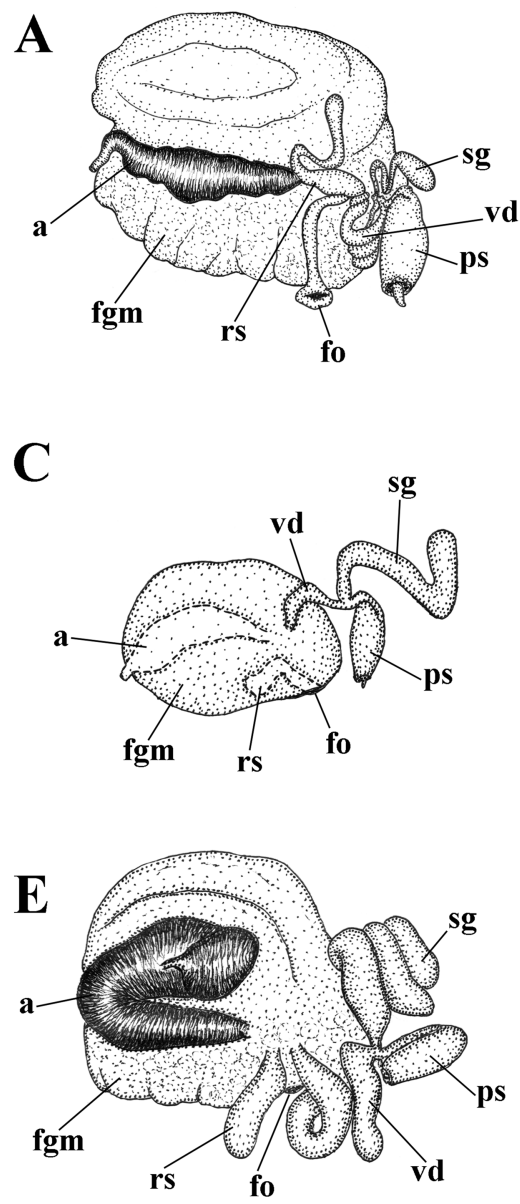

B

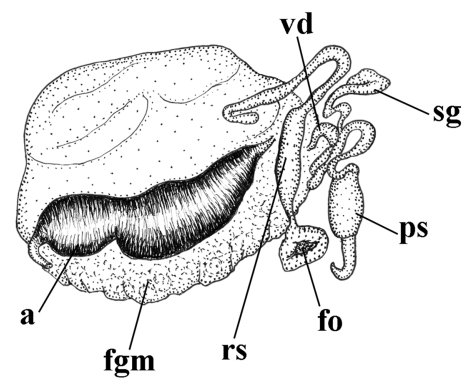

D
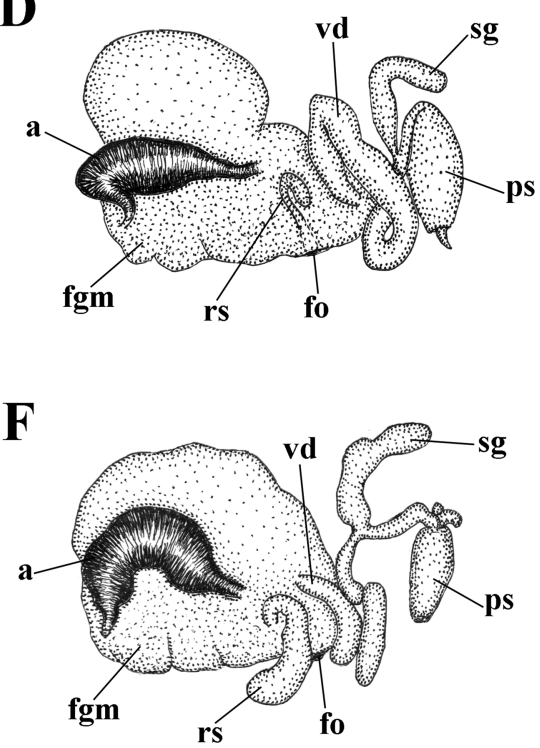

FIGURE 19 Reproductive systems of the genus Cuthonella. A, Cuthonella abyssicola abyssicola; B, Cuthonella abyssicola kryos subsp. nov.; C, Cuthonella ainu sp. nov.; D, Cuthonella benedykti sp. nov.; E, Cuthonella concinna concinna; F, Cuthonella concinna bellatula subsp. nov. Abbreviations: a, ampulla; fgm, female gland mass; fo, female opening; ps, penial sheath; rs, receptaculum seminis; sg, supplementary gland; vd, vas deferens.

By a combination of morphological characters Cuthonella vasentsovichi sp. nov. readily differs from any previously described Cuthonella species. Morphological analysis also reveals considerable differences in the denticulation of the central teeth between C. vasentsovichi sp. nov. (fig. 18) and any related species, e.g., $C$. ainu sp. nov., $C$. denbei sp.nov., $C$. hiemalis, and others from this clade (figs $6,7,10-12,14,17$ ). Externally $C$. vasentsovichi sp. nov. differs from all known species of the genus Cuthonella by a peculiar "shaggy" appearance of numerous, densely placed cerata (fig. 18A). The large number of ceratal rows makes $C$. vasentsovichi sp. nov. partially resemble Cuthonella abyssicola s.l. (figs 4, 5), but $C$. vasentsovichi differs in having a broader body with greyish to greenish colouration instead of reddish or light pinkish, and by the morphology of its radula and reproductive system. Such multilevel differences between the new species and the type species are remarkable and align well with the recently proposed scheme of multilevel organismal diversity (Korshunova et al., 2019b). For a morphological comparison with other Cuthonella species, see table 2. 

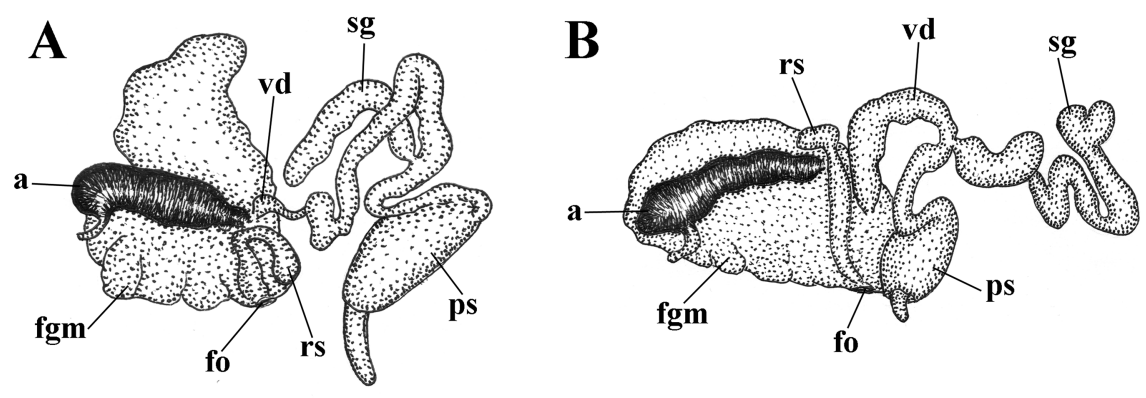

C
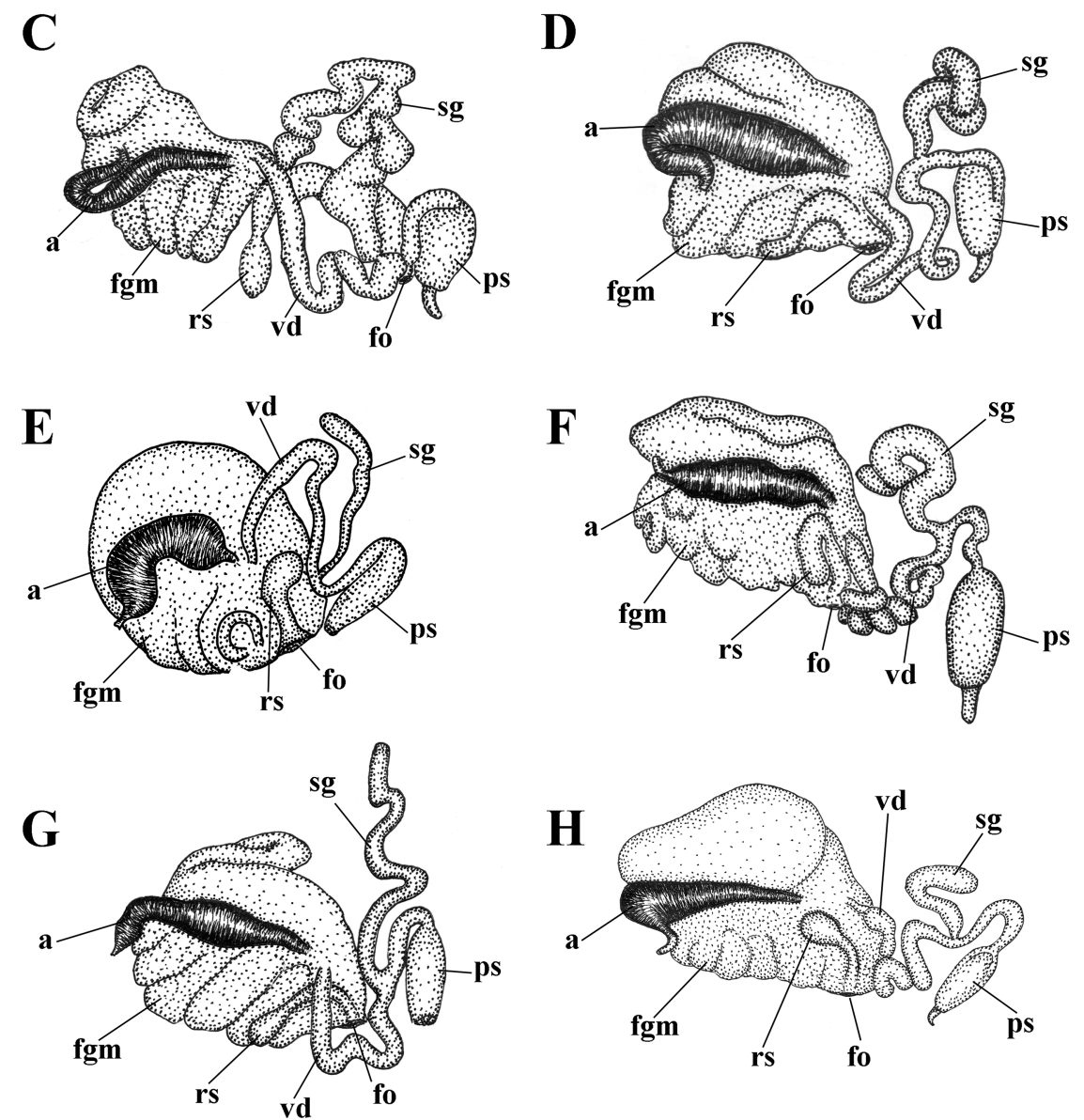

FIGURE 20 Reproductive systems of the genus Cuthonella. A, Cuthonella denbei sp. nov.; B, Cuthonella georgstelleri sp. nov.; C, Cuthonella hiemalis; D, Cuthonella orientosiberica sp. nov.; E, Cuthonella osyoro; F, Cuthonella punicea; G, Cuthonella soboli; H, Cuthonella vasentsovichi sp. nov. Abbreviations: a, ampulla; fgm, female gland mass; fo, female opening; ps, penial sheath; rs, receptaculum seminis; sg, supplementary gland; vd, vas deferens. 


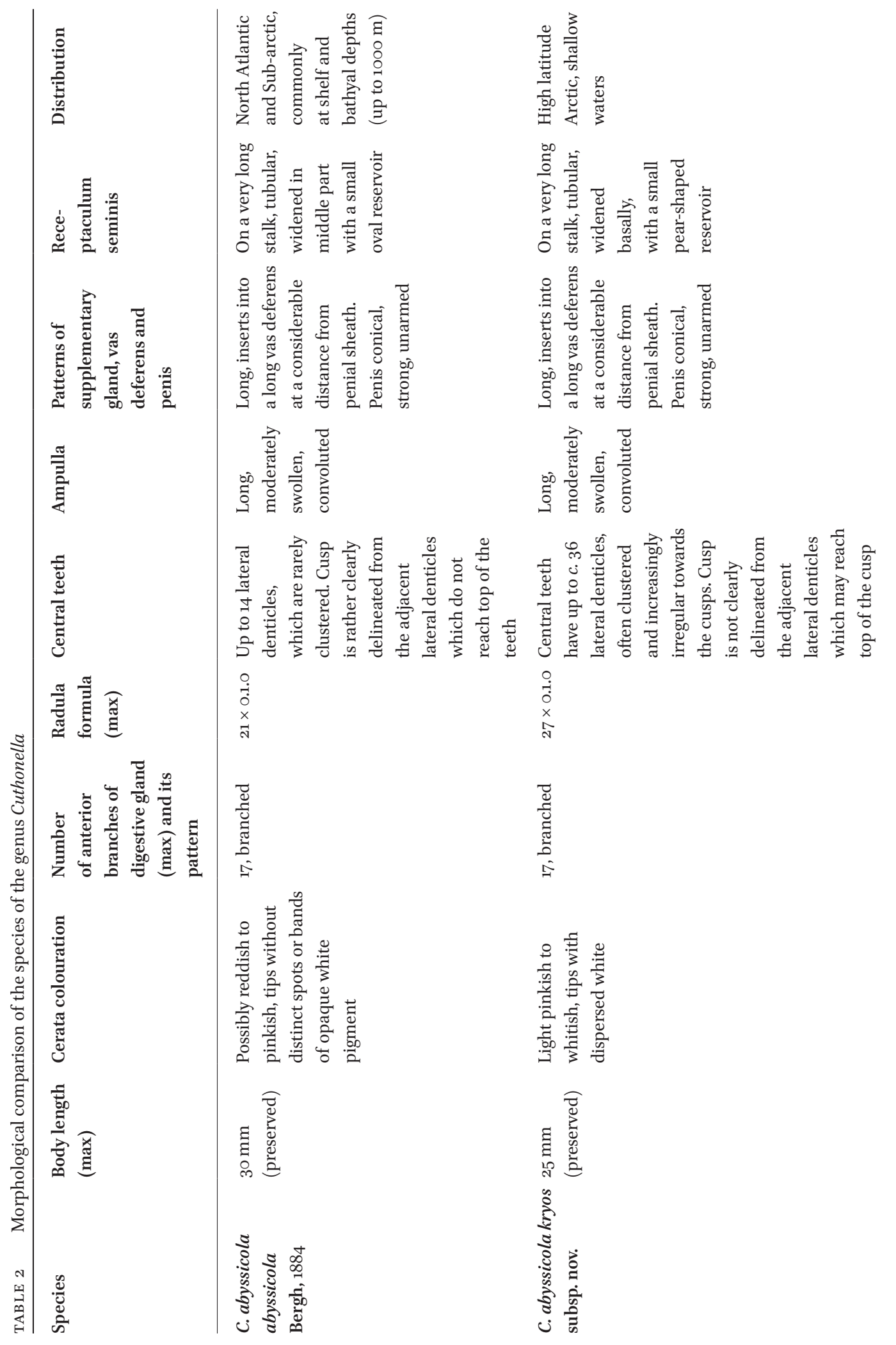




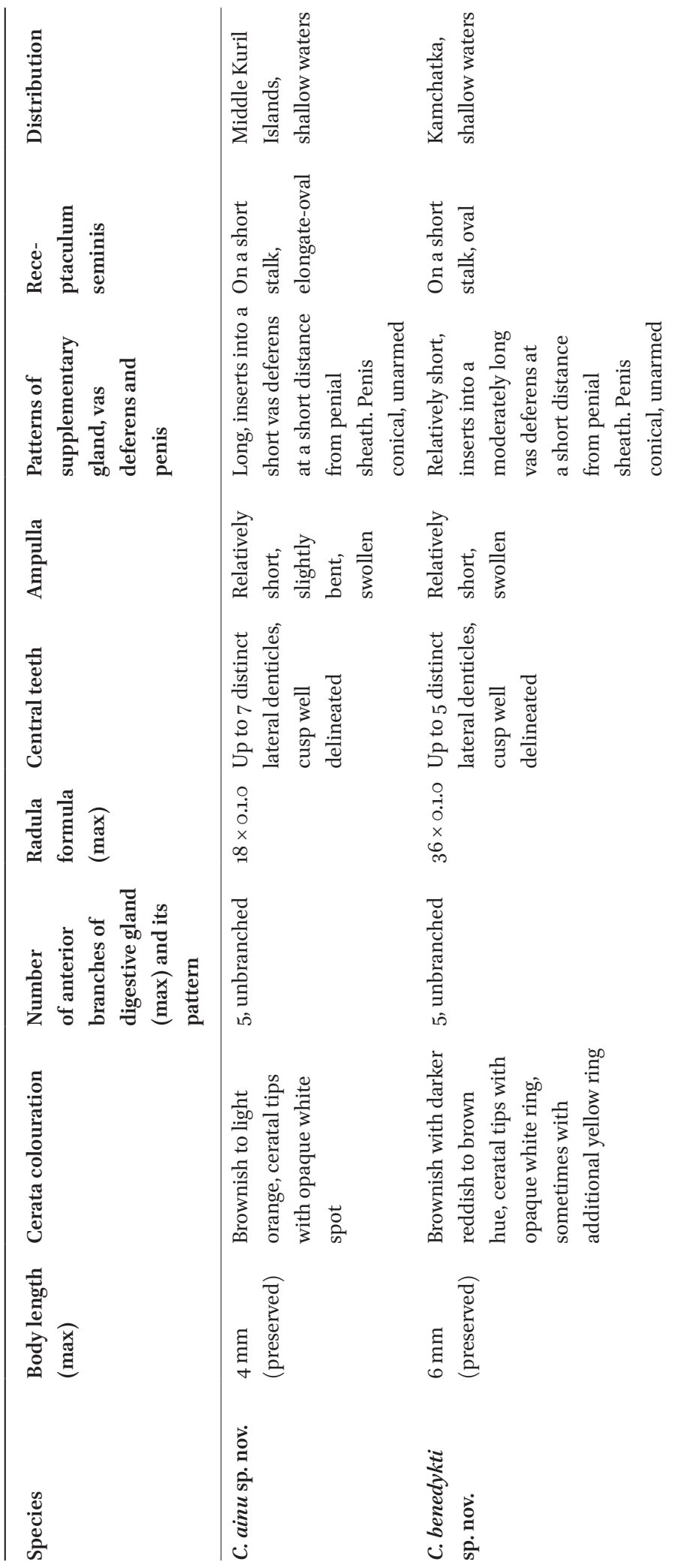









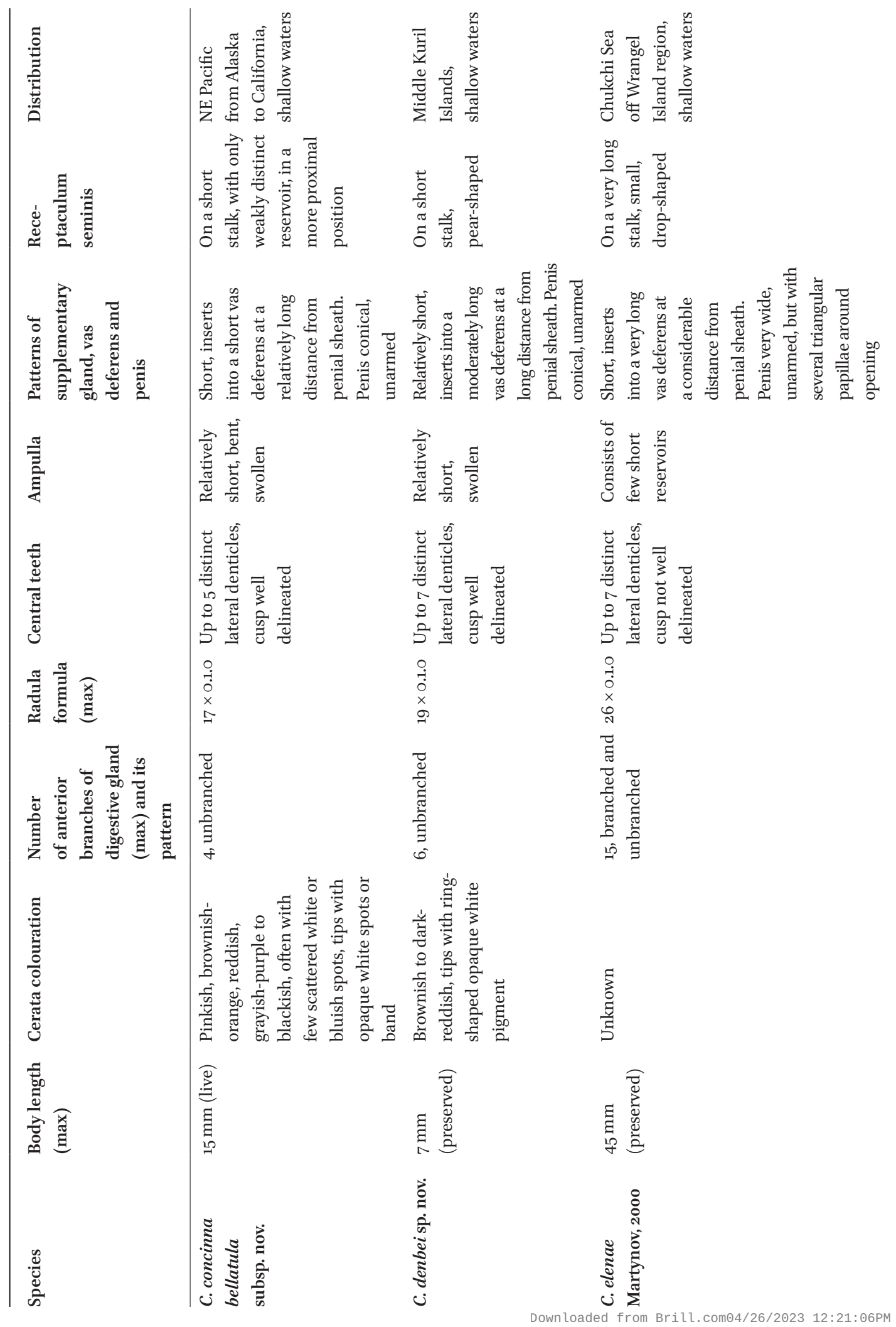




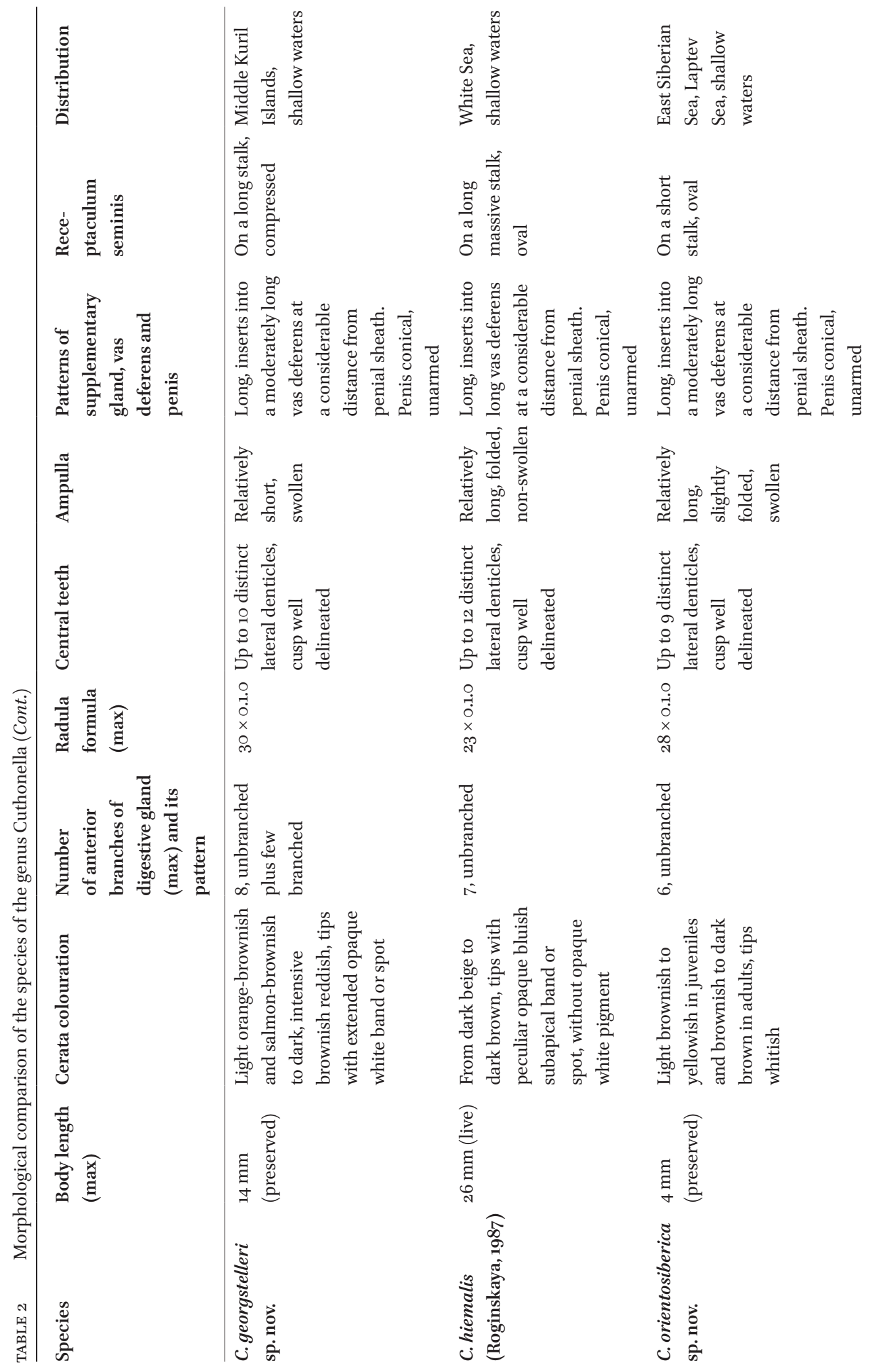




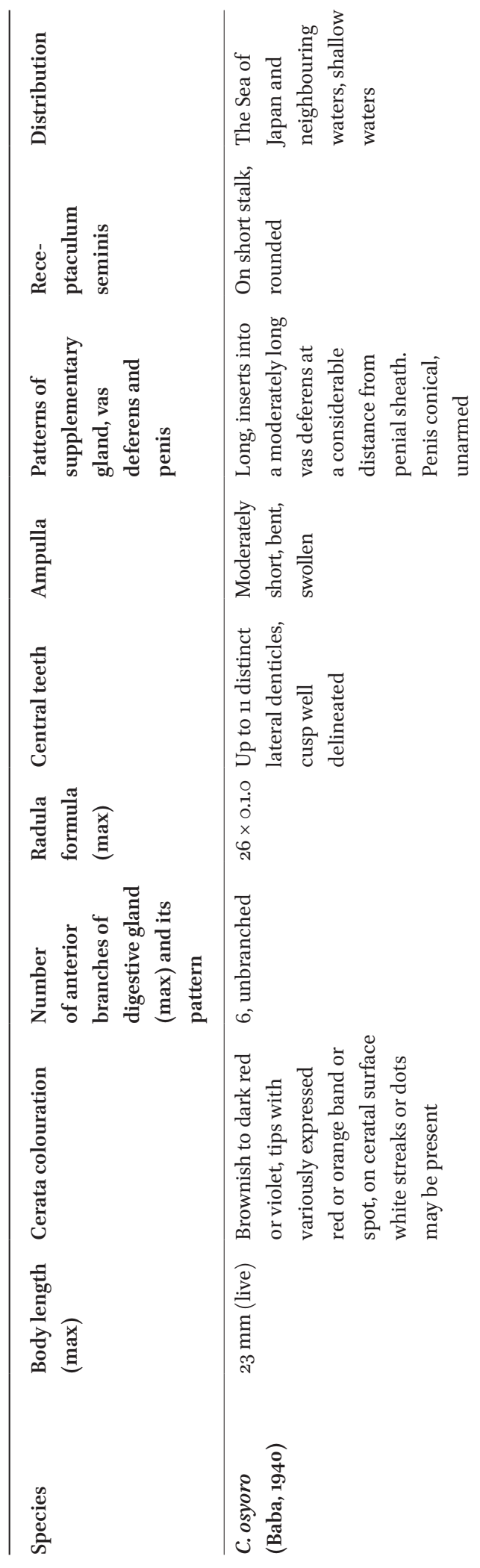

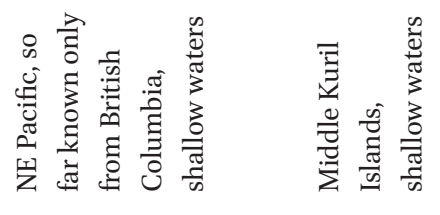

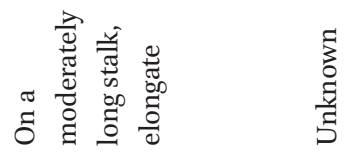

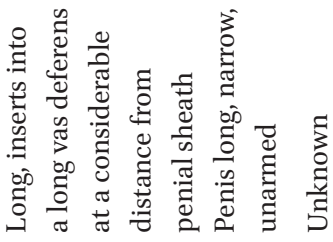

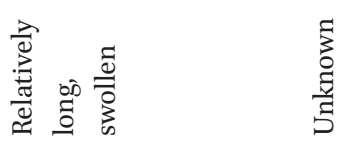

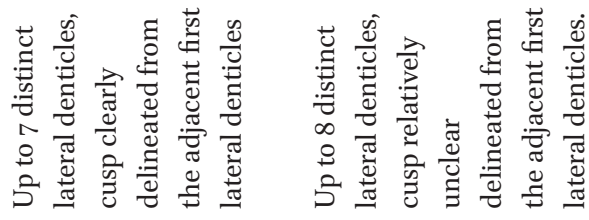

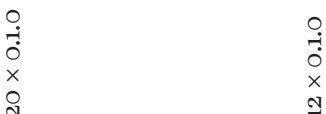

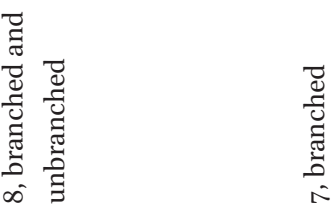

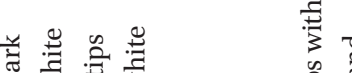

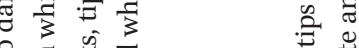

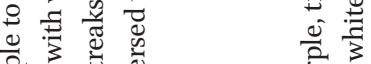

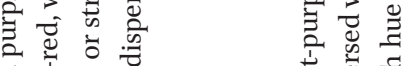

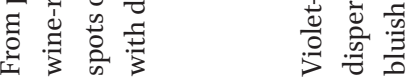

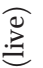

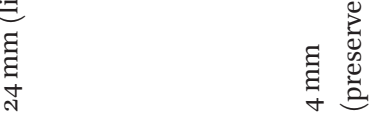

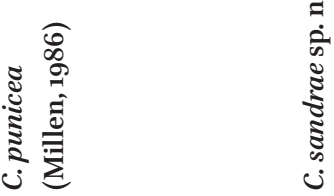




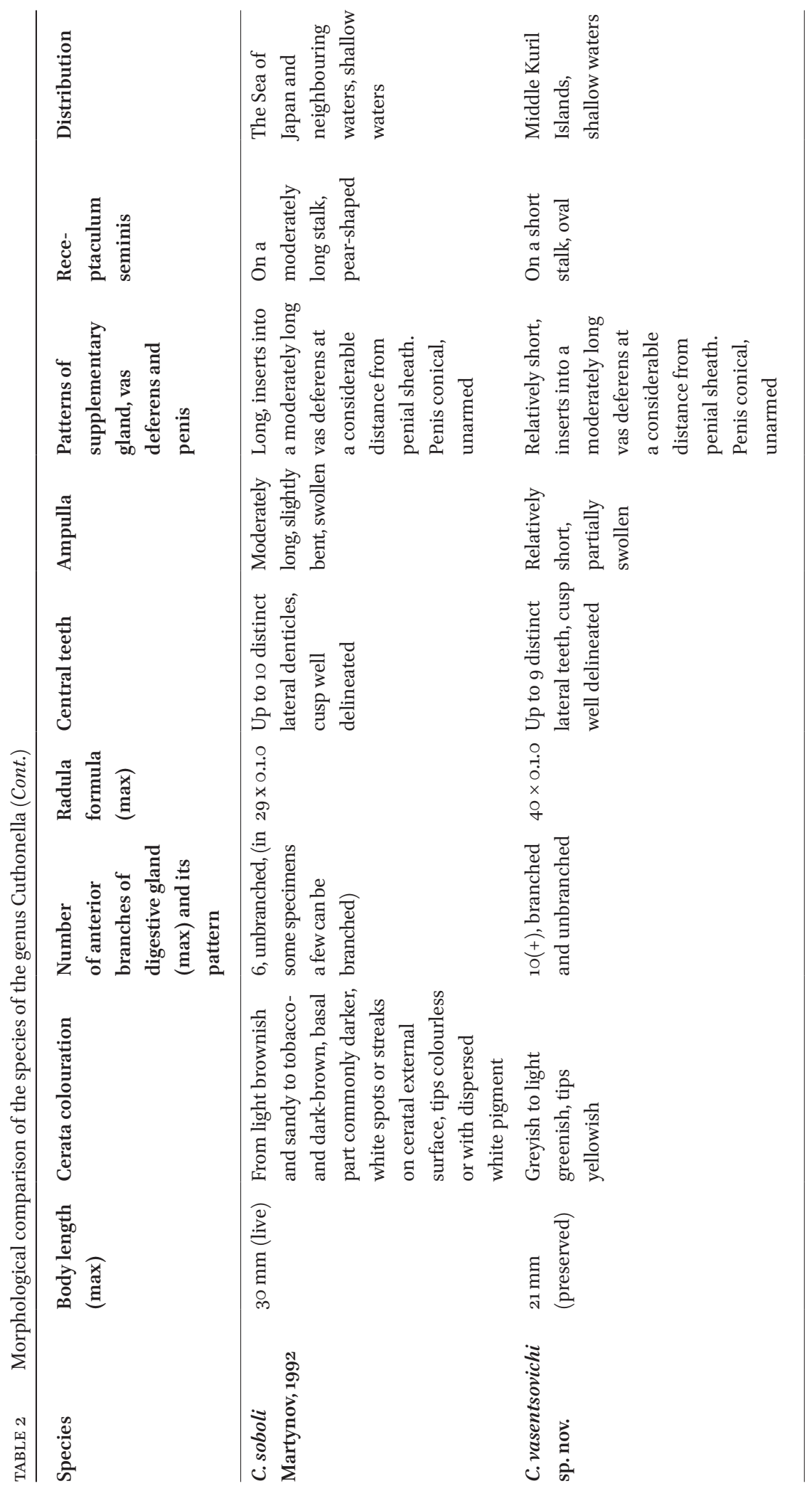




\section{Discussion}

\section{Cold-water biodiversity hotspot: the Cuthonella case}

In the past five years, our knowledge of the nudibranch fauna of the Arctic Sea and the Northwest Pacific Ocean has advanced substantially (e.g., Martynov et al., 2015a, b, 2020b; Korshunova et al., 2016a, b, 2017a, c, 2018a, b). Prior to that, Cuthonella species from these areas, such $C$. hiemalis and $C$. soboli, were shown to have direct development, i.e. without a planktonic stage (Roginskaya, 1987; Martynov, 1992). Although we have no data for the developmental patterns of our newly described species from the NW Pacific, five of them belong to the same clade as $C$. hiemalis and $C$. soboli according to our molecular data (figs 1,2). Therefore, it is plausible to suggest that these species may also have direct or a shortened planktonic development as they inhabit essentially the same cold-water environment. Direct development implies limited dispersal capabilities, and hence more opportunities to form separate species. For other marine invertebrates, an increasing rate of speciation has been linked to direct development (e.g., Hurtado et al., 2017).

Thorson (1950), in his study of the reproductive and larval ecology of marine bottom invertebrates, concluded that direct or other non-feeding development is the dominate reproductive mode in polar waters. Therefore, a higher proportion of directdevelopment nudibranch species might be found in cold-water and polar regions. Although "Thorson rule" has been contested, recent broad-scale analyses confirm its validity in several groups (e.g. Fassio et al., 2019). Alternately, planktonic development has been noted for $C$. concinna s.l., $C$. cocoachroma and C. punicea (Thompson \& Brown, 1984; Goddard, 1992; Millen, 1986), however these three species occur in relatively temperate conditions of the North Atlantic and the NE Pacific respectively, compared to the very cold NW Pacific (including the Kuril Islands), where negative sea water temperatures can occur in the wintertime. The Kuril Islands group, including Matua Island, are a chain of active volcanic islands (e.g., Blokh et al., 2018). They are located on the edge of the continental shelf and are in the confluence of the southward flowing Oyashio current and the Western Subarctic gyre (Qiu, 2001). Matua is a small island, only about $11 \times 6.5 \mathrm{~km}$, essentially just the top of a volcano.

Five new species (C. ainu sp. nov., $C$. denbei sp. nov., C. georgstelleri sp. nov., C. sandrae sp. nov. and $C$. vasentsovichi sp. nov., see descriptions above, figs $1,2,6,10,11,16,18$, 21) were discovered in the shallow waters of this island, plus the new species $C$. benedykti sp. nov was discovered from a neighbouring Kamchatka locality (figs 7,21 ). This peculiar geologic composition and the geographic position between the warm Japanese waters with abundant fauna, the Arctic sea, and the oceanic currents, supports a high abundance of marine life and active speciation.

We therefore suggest that the coldwater biodiversity hotspot exemplified by the cuthonellids is a result of the special biogeographic conditions coupled with direct development among some species. Because several Cuthonella species occur sympatrically in a restricted area, we suggest that they could have originated by a directdevelopment-driven evolution in isolated narrow areas in relatively remote parts of the middle Kuril Islands and adjacent regions. In contrast, for the North Atlantic subspecies from temperate waters such as $C$. concinna concinna, planktonic development has been documented (Roginskaya, 1987; Martynov \& Korshunova, 2011). This suggests a case of allopatric speciation between the North 


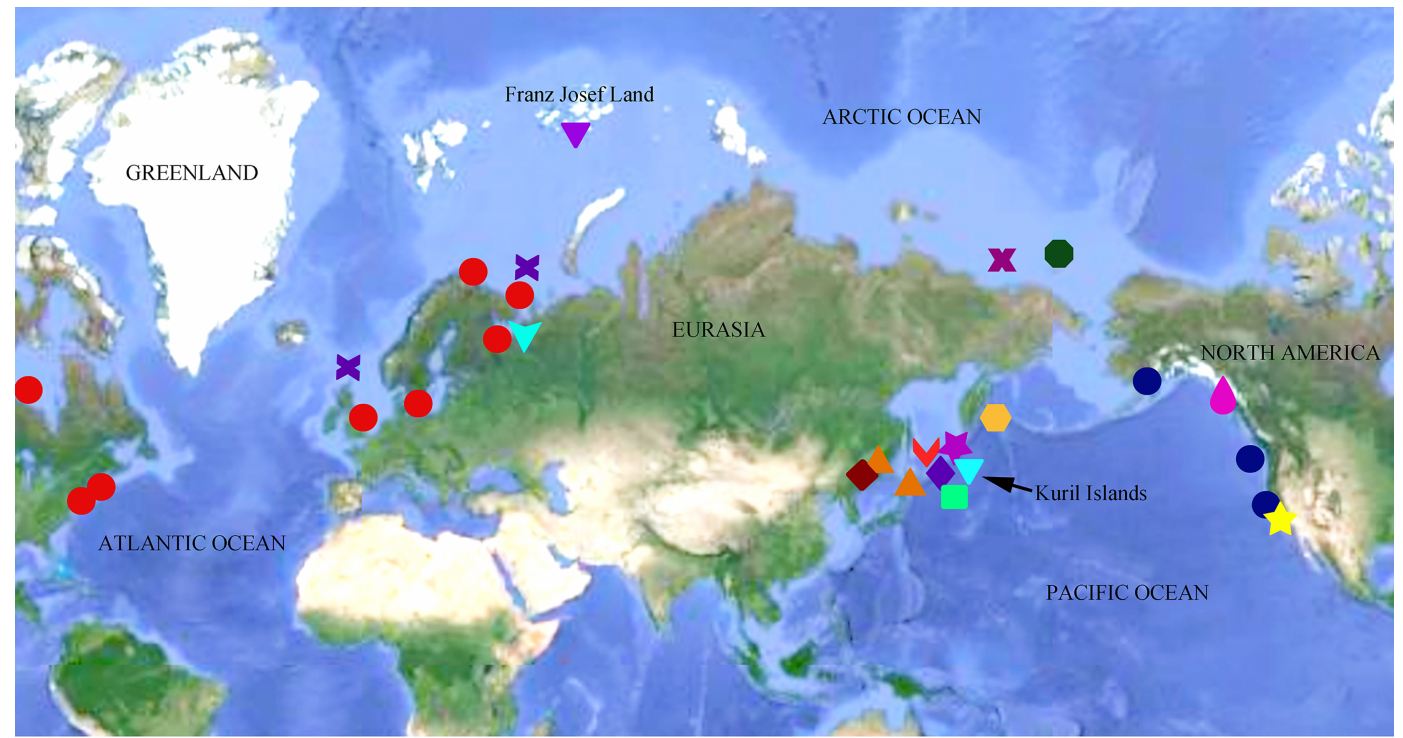

Cuthonella abyssicola abyssicola

Cuthonella cocoachroma

- Cuthonella elenae

$\checkmark$ Cuthonella hiemalis

- Cuthonella osyoro

Cuthonella punicea

- Cuthonella soboli

- Cuthonella concinna concinna $\checkmark$ Cuthonella abyssicola kryos subsp. nov. Cuthonella ainu sp. nov.

Cuthonella benedykti sp. nov.

$\checkmark$ Cuthonella denbei sp. nov.

- Cuthonella georgstelleri sp. nov.

X Cuthonella orientosiberica sp. nov.

$\checkmark$ Cuthonella sandrae sp. nov.

4 Cuthonella vasentsovichi sp. nov.

- Cuthonella concinna bellatula subsp. nov.

FIGURE 21 World map showing the distribution of Cuthonella species. Coloured symbols are indicated on the figure.

Atlantic $C$. concinna concinna and its sister NE Pacific subspecies $C$. concinna bellatula subsp. nov. Allopatric speciation has previously been well documented from various species of nudibranchs (e.g., Korshunova et al., 2018b, 2020a). The reasons why the biodiversity hotspot for cuthonellids in the Middle Kuril Islands has not been recognised before can be explained by both insufficient sampling and a deficit of taxonomic reviews for this region.

\section{Taxonomy of Cuthonella: a morphological} prediction and molecular confirmation The genus Cuthonella Bergh, 1884 was until quite recently only considered valid by a few authors (e.g., Odhner in Franc, 1968; Miller,
1977), especially after the genus Cuthonella was synonymized with the genus Cuthona (Millen, 1986). After 1986, Cuthonella was replaced by Cuthona Alder \& Hancock, 1855 in descriptive papers and guide books (e.g., Behrens \& Hermosillo, 2005). However, in 1992 it was shown that the genus Cuthonella differs considerably from the genus Cuthona and from any other genera of the traditional tergipedids according to the morphology of the reproductive system and so it was considered a valid taxon (Martynov, 1992, 2002, 2006b; Martynov \& Korshunova, 2011) (fig. 22A).

Only since the work of Martynov (1992) was a diagnosis for the genus provided which characterized the genus (fig. 22A). The genus 
Cuthonella was expanded to encompass not only the deep-sea type species, but also shallow-water species such as $C$. concinna s.l., C. hiemalis, $C$. punicea and $C$. soboli. Recently, the validity of the genus Cuthonella was supported by molecular phylogenetic studies (Korshunova et al., 2017b, 2018a; Martynov et al., 2O2Oa), albeit with few species involved. In the present study, we confirm the validity and monophyly of the genus Cuthonella by involving a considerably broader species diversity of the genus (figs 1, 2, 21). This is the largest expansion of the number of species of the genus Cuthonella since 1992 and one of the largest recent expansions of described diversity among northern nudibranchs.

Here we present novel molecular data for a species that is morphologically similar to $C$. abyssicola, the type species of the genus Cuthonella. It is separated here as $C$. abyssicola kryos subspec. nov. This subspecies clusters together with other species included in this study, forming a well-supported monophyletic group (fig. 1). In total, we obtained and analysed molecular data for 13 of the 15 currently recognised species of the genus. For all species of Cuthonella, except for C. cocoachroma (which was unavailable for our morphological study), we confirmed that the supplementary gland in the male part of the reproductive system is inserted into the vas deferens instead of the penis. Hence, this is a well-supported morphological synapomorphy for the genus Cuthonella. For $C$. cocoachroma, Williams \& Gosliner (1979) reported that the supplementary gland inserts into the penis instead of the vas deferens. Since the insertion of the supplementary gland into the vas deferens is a very stable morphological character among species in the genus Cuthonella according to our data, there are at least two possibilities for $C$. cocoachroma. The first is that in this species, a supplementary gland inserting into the penis has evolved in parallel to the families Cuthonidae and Cuthonellidae. The second is that the supplementary gland in C. cocoachroma in reality inserts into the vas deferens, but closer to the penis, and this was missed by Williams \& Gosliner (1979). Except for this detail, the genus Cuthonella appears to be very consistent internally among all examined species, with the presence of an unarmed penis and protruding radulae cusps in most of the species.

External morphological features vary considerably within the species of the genus Cuthonella. The type species, Cuthonella abyssicola s.l., and some species such as C. sandrae sp. nov. and C. punicea, possess branched anterior ceratal rows and may have a cleioproctic anus. Instead, other species, such as $C$. ainu sp. nov., $C$. benedykti sp. nov., $C$. hiemalis, C. concinna s.l., C. soboli, and C.osyoro, possess unbranched anterior ceratal rows and an acleioproctic anus. The correlation of these features with molecular phylogenetic data is quite a mosaic (figs 1, 2, 4-9, 14, 17), so at this stage we have not separated more genera, but retained just the one the genus Cuthonella within the family Cuthonellidae, though with more data more genera will most likely be necessary. Therefore, we do not synonymise the previously established subgenus Fiocuthona with the type species C. concinna s.l. (Martynov, 1992) or further differentiating the taxonomic structure of the family Cuthonellidae pending more data from other species.

In total, the species diversity within the genus Cuthonella has now increased over threefold, from five valid species (Martynov, 1992) plus two which are verified here as synonyms, C. marisalbi (Roginskaya, 1963) and C. distans (Odhner, 1922), to the current 15 species and two subspecies (figs 1, 2, 21), thus confirming the phylogenetic pattern of the almost 30-year-old prediction based on morphology (Martynov, 1992). 


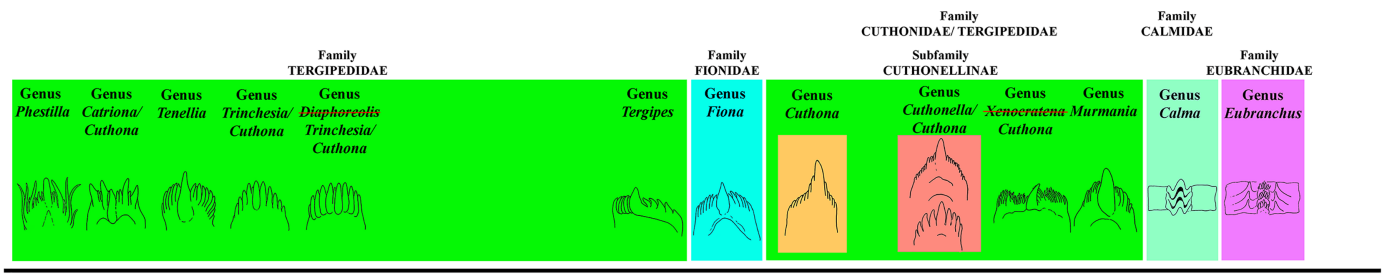

B

RATIONALE: "The range in variation in the length of the central cusp to the lateral denticles in one species proves that variation cannot be used to distinguish genera".

CONCLUSIONS: "We have opted to adopt a broader view, where the larger monophyletic group is considered a genus."

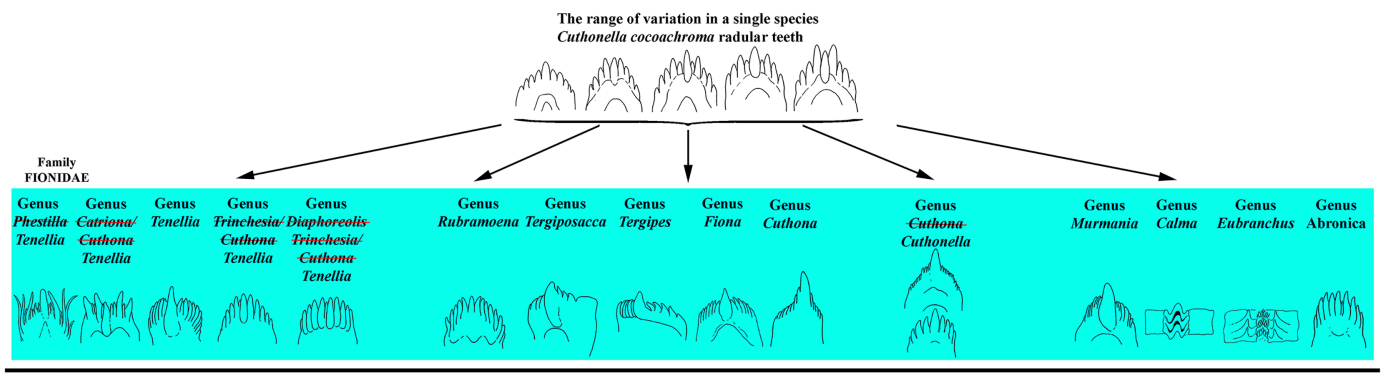

C

Since 2017 - present

RATIONALE: "The range of variation in a single species does not overlap the broad range of radula diversity within the same family."

CONCLUSIONS: "The application of the narrow-taxa concept considerably helps to uncover hidden diversity within particular clades instead of masking it in frames of large, morphologically very diverse taxa". (Korshunova et al., 2017a,b, 2018a; Martynov et al., 2020a)

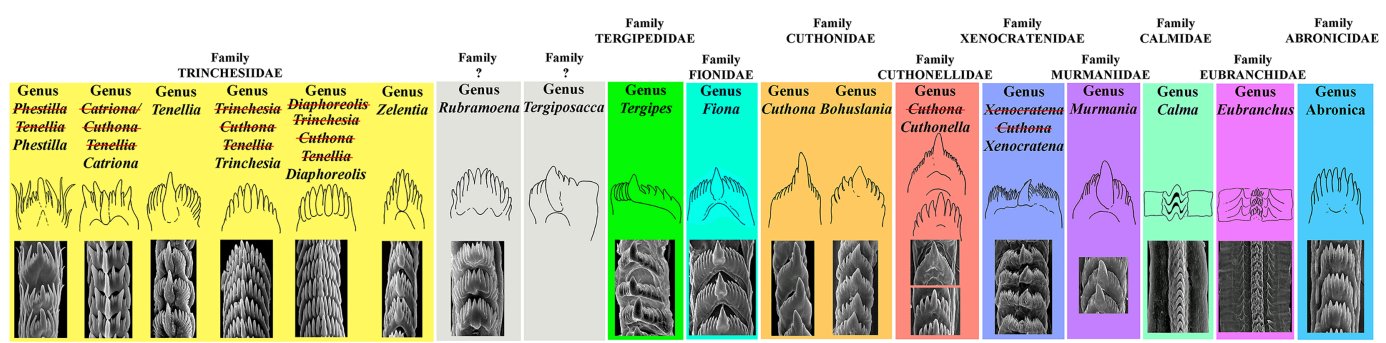

FIGURE 22 Discussion of the radula characters and fine-scale diagnostics in the taxonomy of the former "tergipedid" families. A. Taxonomic composition of the tergipedid aeolidacean nudibranchs before 2016. B. A 'superlumping' aggregation of the "family Fionidae sensu latissimo" (Cella et al., 2016; Epstein et al., 2019) lacking morphological apomorphies. C. Modern fine-scale tergipedid taxonomy that integrates molecular data and provides morphological apomorphies for several separate families and genera (Korshunova et al., 2017a, b; 2018a,b, 2019a, b; Mehrotra et al., 2020). The crossed-out taxon names signify a change in the genus status, the normally displayed names signify valid taxa at every consequential level of the history of the taxonomy of this group. All drawing schemes and SEM images are original. 


\section{Fine-scale differentiation of the family Cuthonellidae}

One practical question should be particularly addressed in respect to the revision of the genus Cuthonella. Marcus (1958) noted that the degree of protrusion of the central cusp of the radular teeth can vary within the same species among the traditional "tergipedid" group. Recently, Korshunova et al. (2017a) demonstrated that various genera or groups of genera, particularly within the family Trinchesiidae, have their own peculiar patterns of radular teeth, not just because of the degree of the relative height of the central cusp and lateral teeth, but also because of patterns that integrate several specific traits.

For example, the genera Trinchesia s.str. and Diaphoreolis have arch-shaped teeth with the central cusp similar in length to the central teeth. The genus Catriona, as another example, has a central cusp, not just lower than the lateral denticles but strongly retracted, making the general shape of the teeth a distinctive trait (fig. 22). The genus Phestilla also has a special combination of long needle-like teeth and a lower central cusp covered with smaller denticles (fig. 22). None of these trinchesiid radular patterns show similarity to those of the family Cuthonellidae and the genus Cuthonella (fig. 22B). The genus Tenellia s.str. (the family Trinchesiidae, fig. $22 \mathrm{C}$ ) has a peculiar tooth shape, displaying only little variation, contrary to the statement in Epstein et al. (2019).

According to the molecular phylogenetic data, the family Cuthonellidae forms a wellsupported clade, which is only distantly related to the Trinchesiidae (Korshunova et al., 2017b, 2018a; Martynov et al., 2019, 2020a). When more of the diversity within the essentially tropical Trinchesiidae and coldwater Cuthonellidae will be investigated, with successively finer differentiated characters and an increasing number of monophyletic subclades, it will be necessary to establish more genera. The old notion that if genera have some putative overlap of morphological patterns (Mayr, 1969; Gosliner \& Griffiths, 1981) they should be merged into a single large genus, without morphological apomorphies (fig. 22B), is counterproductive to phylogenetic investigation.

Obviously, with such an approach an integrative taxonomy involving morphology and molecular analysis will be contradictory. We have already clearly demonstrated this fact for the "superlumping" concept of the "family Fionidae" s.l. (fig. 22), which has no reliable morphological apomorphies (see discussion in Korshunova et al., 2017a). Only narrower, more finely defined taxa of genus- and family groups can be used to integrate morphological and molecular data (Korshunova et al., 2017b, 2020a, b, c) (fig. 22C).

These integrative arguments were not understood and were contradicted recently and labelled "cumbersome" and based on "dubious, minor characters" by Epstein et al. (2019).Notably,itwasareverse reiteration of the argument from our previous study (Martynov, 1992) regarding the genus Cuthona: "if (one) does not intend to create a cumbersome, unnatural genus Cuthona, it is necessary to apply a less lumping approach than what has been applied by most of the recent authors" (translated from Russian; Martynov, 1992: 23). Further molecular analysis (see discussions in Korshunova et al., 2017a, 2018a, b, c; Martynov et al., 2020a) confirmed the conclusions of that almost 30-year-old study. The "Cuthona sensu lato" was revealed as a large polyphyletic assemblage and Cuthona s.str. was then limited to only a few morphologically similar species. Importantly, the genus Cuthonella was shown to be neither closely related to Cuthona nor Trinchesia. When defining the characters of the "family Fionidae sensu latissmo" Cella et al. (2016) (fig. 22B) used characters that are not present in the type genus Fiona, like a 
penial gland, and hence the real Fionidae s.str. has a reproductive system as well as patterns of external morphology that are drastically different from any other "Fionoidea". In table 3 of our 2017 study (Korshunova et al., 2017a) we mentioned the relative height of the central cusp and formally described the differences in the shape of the teeth along with several other characters, and thus did not build a classification solely on a single character. Moreover, Eubranchidae have a triserial radula, Calmidae have radula with fused teeth, and both conditions are very different from the uniserial radula of Cuthonella (fig. $22 \mathrm{C}$ ). Furthermore, Epstein et al. (2019) based their arguments on an older drawing based on light microscopy studies in Williams \& Gosliner (1979, fig. 5) without any additional SEM study.

To present modern comparative morphological data, in this study we made a thorough SEM investigation of a majority of the species of the genus Cuthonella (figs 4-18). We specially show that in some species of Cuthonella, e.g., C. concinna s.l., C. denbei sp. nov., and C. osyoro, the relative height of the central cusp and lateral denticles can vary to some degree between the anterior and posterior teeth (figs 8O-R, $10 \mathrm{G}-\mathrm{I}, 14 \mathrm{~J}-\mathrm{L}$ ), but they never attain any similarity in the general radular pattern to any of the trinchesiid genera (fig. 22).

Furthermore, in this study we made a novel review of data for all species of the genus Cuthonella, including seven new ones (figs 1-21), and none of the species possess radular teeth that have a similar pattern to any trinchesiid genera (Korshunova et al., 2017a) (fig. $22 \mathrm{C}$ ). Therefore, the conclusion that the shape of the radular teeth cannot be used as taxonomic characters in Fionoidea (fig. 22B) is incorrect, and to the contrary, these characters are very useful for taxonomy in an integrative context. It is important to highlight that it is pointless to make a classification using only radular characters and to argue that if radulae among some taxa demonstrate some similarities or similar variabilities these taxa must automatically be synonymized.

Instead, every taxon at the family- and genus-level demonstrates a complicated multilevel mosaic of morphological characters (including potentially a big disparity between characters of different organ systems) and molecular features. Any diagnosis that professes to encompass a complex evolutionary history in a classification must be based on such multilevel differences, and not on simplistic binary alternatives such as "presence" or "absence", "lower" or "higher" or on an overestimated "variability".

Recently, the obvious problems of the 'superlumping' approach were revealed within the large aeolidacean group in which a very complex molecular pattern was shown to be aligned with an extremely mosaic distribution of morphological characters (Korshunova et al., 2017b, 2019a, b; Martynov et al., 2O2Oa). In conclusion, to have a 'superlumping' name for such a group, one has to go much further than to unite many disparate taxa into a single "family Fionidae" but to unite all order-level diversity of the Aeolidacea into a single family, Aeolidiidae. This would lead to a morphologically non finely diagnosable group, with only the most general potential apomorphy (possession of a cnidosac at the extremity of each ceras) which corresponded to the taxonomic level of order/ suborder, and not to the family level, because a majority of aeolidaceans from any family possess a cnidosac.

However, even such a potential general apomorphy would be problematic since several non-related genera lack cnidosacs, e.g., Phestilla Bergh, 1874 in the family Trinchesiidae or Phyllodesmium Ehrenberg, 1831 in the family Myrrhinidae. In contrast, when separating many finely defined 
families and genera, including Abronicidae, Calmidae, Cuthonellidae, Cuthonidae, Eubranchidae, Fionidae s.str., Tergipedidae, Trinchesiidae, Xenocratenidae, Murmaniidae, and potentially several others (fig. $22 \mathrm{C}$ ), it facilitates making complex morphological diagnoses and a list of morphological apomorphies that is maximally consistent. Importantly, it is also concordant with the molecular data. Every narrowly defined family and genus has its own set of finely scaled characters, that, if taken separately, may be incorrectly considered "overlapping" ones.

The pitfalls of the 'superlumping' approach can immediately influence practical taxonomy. For example, the maximally broad approach that evoked the single huge "family Fionidae" (which then "overlaps" by almost all possible morphological apomorphies with all other aeolid families, see Korshunova et al., 2017a, 2019a) led to the result (Cella et al., 2016) of failing to distinguish two externally similar taxa with drastically different internal morphologies: Cuthonella punicea (Millen, 1986) and Zelentia nepunicea Korshunova et al., 2018.

Thus, the maximally broad approach (e.g., Williams \& Gosliner, 1979; Epstein et al., 2019) not only "does not permit other users of the classification (largely other comparative biologists) to identify taxa readily from living examples", but clearly misleads nudibranch taxonomists per se. Alternately, the fine-scale approach of numerous narrowly-defined families and genera easily avoids such pitfalls: Cuthonella punicea belongs to the family Cuthonellidae, whereas Zelentia nepunicea belongs to the family Trinchesiidae. Both families have a minimally overlapping particular set of morphological characters (which of course are not absolutely "stable" because of the continuing evolutionary process) and show significant molecular divergence, and thus are only distantly related to each other (Korshunova et al., 2017a, b, 2018a, b, 2019b).
Most recently, our fine-scale approach was supported by an independent study of the tropical trinchesiid genus Phestilla (Mehrotra et al., 2020). The review presented here of the genus Cuthonella and the family Cuthonellidae is therefore of high relevance for demonstrating the benefits of this approach, since this is a properly narrow family and genus, whose validity has been confirmed first by using morphological data (Martynov, 1992; Martynov \& Korshunova, 2011) then recently by the application of molecular data in Korshunova et al. (2018a) and finally by the addition of seven new species and two new subspecies detailed in this study.

\section{Acknowledgements}

Sandra Millen (University of British Columbia) is thanked for providing the type specimens of Cuthonella punicea and helping to organize the collecting trip. Doug Miller and Neil McDaniel are warmly thanked for collection of specimens of $C$. punicea. Oleg Savinkin (The Institute of Ecology and Evolution RAS) is thanked for collecting and providing specimen from Franz Josef Land. B.I. Sirenko, S.Y. Gagaev, and A.Y. Voronkov (Zoological Institute RAS) are thanked for collecting and providing specimens from East Siberian Sea and images. Our gratitude goes to Bernard Picton (National Museums of North Ireland) for collection of specimens of C. concinna concinna from the British Isles and to Klas Malmberg (Universeum and Aquatilis, Gothenburg) for collection of specimens of $C$. concinna concinna from Sweden. T.A. Bakke and Kjersti Kvalsvik are thanked for the loan of specimen from the Oslo Natural History Museum. So Ishida (Osaka Museum of Natural History) and Sho Kashio (Natural History Museum of the Kishiwada City, Osaka) are thanked for help 
with access to the archived material of Dr. Kikutaro Baba. The team of Gulen Dive Resort (Christian Skauge, Ørjan Sandnes, Monica Bakkeli and Guido Schmitz) are generously thanked for their help during fieldwork in Norway, as the specimens collected there were used for comparative purposes in this study, and the \#sneglebuss project field team for assistance during field work in Finnmark, Norway. Anna Zhadan (Moscow State University) is thanked for providing some material and images on $C$. hiemalis. Reviewers are thanked for providing comments that helped to improve the paper. Electron Microscopy Laboratory MSU is thanked for support with electron microscopy. The study was supported by the Norwegian Taxonomy Initiative project \#sneglebuss Barents Sea (1918_70184240). The work of AM was supported by the research project of MSU Zoological Museum (AAAA-A16-116o2166oo77-3). The work of TK was conducted under the IDB RAS Government basic research program in 2020 No o108-2019-0002.

\section{References}

Alder, J. \& Hancock, A. (1843) Notice of a British species of Calliopaea, D'Orbigny, and of four new species of Eolis, with observations on the development and structure of the nudibranchiate Mollusca. Ann. Mag. Nat. Hist., 12, 233-238.

Alder, J. \& Hancock, A. (1845-1855) A monograph of the British nudibranchiate mollusca. pt. I-VII. Ray Society, London.

Baba, K. (1940) Some additions to the nudibranch fauna of the northern part of Japan. Bull. Biogeogr. Soc. Japan, 10,103-111.

Bakken, T., Hårsaker, K. \& Daverdin, M. (2020) Marine invertebrate collection NTNU University Museum. Version 1.574. NTNU University Museum. Occurrence dataset https://doi. org/10.15468/ddbs14 accessed via GBIF.org on 2020-08-04.

Barman, A.S., Singh, M., Singh, S.K., Saha, H., Singh, Yu. J., Laishram, M. \& Pandey, P.K. (2018) DNA barcoding of freshwater fishes of IndoMyanmar biodiversity hotspot. Sci. Rep., 8, 8579 .

Behrens, D. (1980) Pacific coast nudibranchs, a guide to the opisthobranchs of the northeastern Pacific. Los Osos, CA, Sea Challengers.

Behrens, D. \& Hermosillo, A. (2005) Eastern Pacific nudibranchs, a guide to the opisthobranchs from Alaska to Central America. Monterey, Sea Challengers.

Bergh, R. (1884). Report on the Nudibranchiata collected by H.M.S. Challenger, during the years 1873-1876. Rep. Sci. Res. Voyage of Challenger, 10, 1-154.

Bickford, D., Lohman, D.J., Sodhi, N.S., Ng, P.K.L., Meier, R., Winker, K., Ingram, K.K. \& Das, I. (2007) Cryptic species as a window on diversity and conservation. Trends Ecol. Evol., 22, $148-155$.

Blokh, Y.I., Bondarenko, V.I., Dolgal, A.S., Novikovac, P.N., Petrova, V.V., Pilipenko, O.V., Rashidova, V.A. \& Trusov, A.A. (2018) The Rikord submarine volcanic Massif, Kuril Island Arc. J. Volcanol. Seism., 12, 252-267.

Bouchet, P, \& Rocroi, J.-P. (2005). Classification and nomenclator of gastropod families. Malacologia, 47, 1-397.

Brinckmann-Voss, A., \& Calder, D. R. (2013) Zyzzyzus rubusidaeus (Cnidaria, Hydrozoa, Tubulariidae), a new species of anthoathecate hydroid from the coast of British Columbia, Canada. Zootaxa, 3666, 389-397.

Brown, G.H. (1980). The British species of the aeolidiacean family Tergipedidae (Gastropoda: Opisthobranchia) with a discussion of the genera. Zool. J. Linn. Soc., 69: 225-255.

Carmona, L., Pola M., Gosliner, T.M., \& Cervera, J.L. (2013) A tale that morphology fails to tell: a molecular phylogeny of Aeolidiidae (Aeolidida, Nudibranchia, Gastropoda). PLoS ONE, 8, e630oo. 
Cella, K., Carmona, L., Ekimova, I., Chichvarkhin, A., Schepetov, D. \& Gosliner, T.M. (2016) A Radical solution: The phylogeny of the nudibranch family Fionidae. PloS One, 11, eo16780o.

Colgan, D., Macaranas, J., Cassis, G. \& Gray, M.R. (1998) Histone $\mathrm{H}_{3}$ and U2 snRNA DNA sequences and arthropod molecular evolution. Austr. J. Zool., 4, 419-437.

Dayrat, B., Tillier, A., Lecointre, G. \& Tillier, S. (2001) New clades of euthyneuran gastropods (Mollusca) from 28S rRNA sequences. Mol. Phylogenet. Evol., 19, 225-235.

Eliot, C.N.E. (1907) Mollusca IV.—Nudibranchiata. Nat. Ant. Exped. 1901-1904. Nat. Hist. Zool., 2, (Vertebrata: Mollusca: Crustacea), 1-28.

Epstein, H.E., Hallas, J.M., Johnson, J.F., Lopez, A. \& Gosliner, T. (2019) Reading between the lines: revealing cryptic species diversity and colour patterns in Hypselodoris nudibranchs (Mollusca: Heterobranchia: Chromodorididae). Zool.J. Linn. Soc., 186, 116-189.

Fassio, G., Modica, M.V., Alvaro, M.V., Buge, B., Salvi, D., Oliverio, M. \& Schiaparelli, S. (2019) An Antarctic flock under the Thorson's rule: diversity and larval development of Antarctic Velutinidae (Mollusca: Gastropoda). Mol. Phylogenet. Evol., 132, 1-13.

Folmer, O., Black, M., Hoeh, W., Lutz, R. \& Vrijenhoek, R. (1994) DNA primers for amplification of mitochondrial cytochrome c oxidase subunit I from diverse metazoan invertebrates. Mol. Mar. Biol. Biotechnol., 3, 294-299.

Friele, H. (1903) Mollusken der ersten Nordmeerfahrt des Fischereidampfers "Michael Sars" 1900, unter der Leitung von Herrn Dr Johan Hjort. Bergens Mus. Aarbog, 3, 1-19.

Goddard, J.H.R. 1985. Food habits of some nudibranchs from Cape Arago, Oregon. Western Soc. Malacol. Ann. Rep., 17, 9-10.

Goddard, J.H.R. (1992) Patterns of development in nudibranch molluscs from the northeast Pacific Ocean, with regional comparisons. Ph.D. Dissertation, University of Oregon, Eugene, Oregon.
Gosliner, T.M. \& Griffiths, R.J. (1981) Description and revision of some South African aeolidacean Nudibranchia (Mollusca, Gastropoda). Ann. South Afr. Mus., 84, 105-150.

Grieg, J.A. (1913) Nudibranchiate Mollusker indsamlede av den norske fiskeridamper "Michael Sars". Norske Vidensk. Selsk. Skr., 13: $1-13$.

Hamond, R. (1972) The marine Mollusca of Norfolk. Trans. Norfolk Norwich Nat. Soc., 22, 271-306.

Hoeksema, B.W. (2007) Delineation of the Indo-Malayan centre of maximum marine biodiversity: The Coral Triangle. In: Renema W. (ed.) Biogeography, time and place: distributions, barriers and islands, pp 117-178. Springer, Dordrecht.

Hurtado, L.A., Mateos, M. \& Liu, S. (2017) Phylogeographic patterns of a lower intertidal isopod in the Gulf of California and the Caribbean and comparison with other intertidal isopods. Ecol. Evol., 7, 346-357.

ICZN (1999) International code of zoological nomenclature. London, The International Trust for Zoological Nomenclature.

Ikuta, M. (2008) Changing Japanese-Russian Images in the Edo Period. In: Japan and Russia. Three centuries of mutual images, Eds Mikhailova Y., Steele M.W.. Global Oriental LTD, Kent, UK, pp. 11-31.

Katoh, K., Misawa, K., Kuma, K. \& Miyata, T. (2002) MAFFT: a novel method for rapid multiple sequence alignment based on fast Fourier transform. Nucl. Acids Res., 30, 3059-3066.

Korshunova, T.A., Sanamyan, N.P., Zimina, O.L., Fletcher, K. \& Martynov, A.V. (2016a) Two new species and a remarkable record of the genus Dendronotus from the North Pacific and Arctic oceans (Nudibranchia). ZooKeys, 630, 19-42.

Korshunova, T.A., Sanamyan, N.P. \& Martynov, A.V. (2016b) Morphological and molecular evidence indicate Dendronotus primorjensis is a valid species that has priority over D. dudkai (Nudibranchia). ZooKeys, 634, 15-28. 
Korshunova, T.A., Martynov, A.V. \& Picton, B.E. (2017a) Ontogeny as an important part of integrative taxonomy in tergipedid aeolidaceans (Gastropoda: Nudibranchia) with a description of a new genus and species from the Barents Sea. Zootaxa, 4324, 1-22.

Korshunova, T.A., Martynov, A.V., Bakken, T., Evertsen. J., Fletcher, K., Mudianta, W.I., Lundin, K., Schrödl, M. \& Picton, B. (2017b) Polyphyly of the traditional family Flabellinidae affects a major group of Nudibranchia: aeolidacean taxonomic reassessment with descriptions of several new families, genera, and species (Mollusca, Gastropoda). ZooKeys, 717, 1-139.

Korshunova, T.A., Zimina, O.L. \& Martynov. A. $(2017 \mathrm{c})$ Unique pleuroproctic taxa of the nudibranch family Aeolidiidae from the Atlantic and Pacific Oceans, with description of a new genus and species.J. Moll. Stud., 83, 409-421.

Korshunova, T.A., Lundin, K., Malmberg, K., Picton, B. \& Martynov, AV. (2018a) First true brackish water nudibranch mollusc provides new insights for phylogeny and biogeography and reveals paedomorphosis driven evolution. PLoS ONE, 13, eo192177.

Korshunova, T.A., Fletcher, K., Lundin, K., Malmberg, K., Picton, B. \& Martynov, A.V. (2018b) The genus Zelentia is an amphi-boreal taxon expanded to include three new species from the North Pacific and Atlantic oceans (Gastropoda: Nudibranchia: Trinchesiidae). Zootaxa, 4482, 297-321.

Korshunova, T.A., Fujita, T. \& Martynov, A.V. (2018c) The first record of Trinchesia lenkae Martynov, 2002 from Japan: morphological and molecular comparison with the material from the type locality in Russia (Nudibranchia: Trinchesiidae). Venus, J. Malacol. Soc. Japan, 76, 19-28.

Korshunova T.A., Mehrotra R., Arnold S., Lundin K., Picton B. \& Martynov A.V. (2019a.) The formerly enigmatic Unidentiidae in the limelight again: a new species of the genus Unidentia from Thailand (Gastropoda: Nudibranchia). Zootaxa, 4551, 556-570.
Korshunova, T.A., Picton, B., Furfaro, G., Mariottini, P., Pontes, M., Prkić, J., Fletcher, K., Malmberg, K., Lundin, K. \& Martynov, A.V. (2019b) Multilevel fine-scale diversity challenges the 'cryptic species' concept. Sci. Rep., 9, 1-23.

Korshunova, T.A., Bakken, T., Grøtan, V., Johnson, K., Lundin, K. \& Martynov, A.V. (2020a). A synoptic review of the family Dendronotidae (Mollusca: Nudibranchia): a multilevel organismal diversity approach. Contrib. Zool., doi:10.1163/18759866-BJA10o14

Korshunova, T.A., Fletcher K., Picton, B., Lundin, K., Kashio, S, Sanamyan, N.P., Sanamyan, K.E., Padula, V., Schrodl, M. \& Martynov, A.V. (2020b) The Emperor Cadlina, hidden diversity and gill cavity evolution: new insights for the taxonomy and phylogeny of dorid nudibranchs (Mollusca: Gastropoda). Zool. J. Linn. Soc., 189, 762-827.

Korshunova, T.A., Malmberg, K., Prkić, J., Petani, A., Fletcher, K., Lundin, K. \& Martynov, A.V. (2O2Oc) Fine-scale species delimitation: speciation in process and periodic patterns in nudibranch diversity. ZooKeys, 917, 15-50.

Kumar, S., Stecher, G., \& Tamura, K. (2016) MEGA7: molecular evolutionary genetics analysis version 7.0 for bigger datasets. Mol. Biol. Evol., 33, 1870-1874.

Marcus, Er. (1958) On western Atlantic opisthobranchiate gastropods. Amer. Mus. Novit., 1906, 1-82.

Marshall, J.G.. \& Willan, R.C. (1999). Nudibranchs of Heron Island, Great Barrier Reef. A survey of the Opisthobranchia (Sea Slugs) of Heron and Wistari Reefs. Leiden, Backhuys Publishers.

Martin, R., Heß, M., Schrödl, M. \& Tomaschko, K.H. (2009) Cnidosac morphology in dendronotacean and aeolidacean nudibranch molluscs: from expulsion of nematocysts to use in defense? Mar. Biol., 156, 261-268.

Martynov, A.V. (1992) A new species of nudibranch molluscs of the Sea of Japan with notes on the genus Cuthonella (Gastropoda, Opisthobranchia). Zool. Zhur., 71, 18-24. 
Martynov, A.V. (1997). Opisthobranch molluscs of the coastal waters of the Commander Islands and remarks on their fauna in the Far-Eastern Seas of Russia. In: Rzhavsky A.V. (ed.) Benthic flora and fauna of the shelf zone of the Commander Islands, pp 117-178. Vladivostok, Dalnauka.

Martynov, A.V. (2000) A new species of Arctic tergipedid Cuthonella elenae sp. nov. (Opisthobranchia, Nudibranchia) off Wrangel Island. Ruthenica, 10, 5-10.

Martynov, A.V. (2002) Two new species of the genus Trinchesia Ihering, 1879 from Peter the Great Bay, Japan Sea (Nudibranchia, Tergipedidae), with notes on the taxonomy of the family. Ruthenica, 12, 45-54.

Martynov, A.V. (2006a) Archaic Tergipedidae of the Arctic and Antarctic: Murmania antiqua gen. et sp. nov. from the Barents Sea and a revision of the genus Guyvalvoria Vayssière with descriptions of two new species. Ruthenica, 16, 73-88.

Martynov, A.V. (2006b) Nudipleura. In - Marine and brackish water Gastropoda of Russia and adjacent countries: an illustrated catalogue, pp. 267-294. KMK Scientific Press Ltd., Moscow.

Martynov, A.V. \& Korshunova, TA. (2011) Opisthobranch molluscs of the seas of Russia. A colour guide to their taxonomy and biology. Moscow, Fiton Press.

Martynov, A.V., Korshunova, T.A. (2012) Opisthobranch molluscs of Vietnam (Gastropoda: Opisthobranchia). In Britayev, T.Z., Pavlov, D.S. (eds.) Benthic Fauna of the Bay of Nhatrang, Southern Vietnam, pp 142-257. KMK Scientific Press, Moscow.

Martynov, A.V. \& Korshunova, T.A. (2017) World's northenmost and rarely observed Nudibranchs: three new Onchidoridid species (Gastropoda: Doridida) from Russian seas. Zootaxa, 4299, 391-404.

Martynov, A.V., Sanamyan, N.P. \& Korshunova, T.A. (2015a) New data on the opisthobranch molluscs (Gastropoda: Opisthobranchia) of waters of Commander Islands and FarEastern seas of Russia. In: Conservation of biodiversity of Kamchatka and coastal waters - Proceedings of XV international scientific conference Petropavlovsk-Kamchatsky, pp. 5569. Petropavlovsk-Kamchatsky, Kamchat Press. Martynov, A.V., Sanamyan, N.P. \& Korshunova T.A. (2015b) Review of the opisthobranch mollusc fauna of Russian Far Eastern seas: Pleurobranchomorpha, Doridida and Nudibranchia. Bull. Kamchatka State Techn. Univ., 34, 62-87.

Martynov, A.V, Mehrotra, R., Chavanich, S., Nakano, R., Kashio, S., Lundin, K., Picton, B. \& Korshunova T. (2019) The extraordinary genus Myja is not a tergipedid, but related to the Facelinidae s. str. with the addition of two new species from Japan (Mollusca, Nudibranchia). ZooKeys, 818, 89-116.

Martynov, A.V., Lundin, K., Picton, B., Fletcher, K., Malmberg, K., \& Korshunova, T.A. (2020a) Multiple paedomorphic lineages of softsubstrate burrowing invertebrates: parallels in the origin of Xenocratena and Xenoturbella. PLoS ONE, 15, eo227173.

Martynov, A.V., Fujiwara, Y., Tsuchida, S., Nakano, R., Sanamyan, N., Sanamyan, K., Fletcher, K. \& Korshunova, T.A. (2020b) Three new species of the genus Dendronotus from Japan and Russia (Mollusca, Nudibranchia). Zootaxa, 4747, 495-513.

Mayr, E. (1969) Principles of systematic zoology. New York: McGraw-Hill.

Mehrotra, R., Arnold, S., Wang, A., Chavanich, S., Hoeksema, B.W. \& Caballer, M. (2020) A new species of coral-feeding nudibranch (Mollusca: Gastropoda) from the Gulf of Thailand. Mar. Biodivers., 50, $3^{6 .}$

Milbakh, V.S. (2003) Repression in the red army in the Far East, 1936-1939. J. Slavic Mil. Stud., 16, 58-130.

Millen, S.V. (1983) Range extensions of opisthobranchs in the northeastern Pacific. The Veliger, 25, 383-386.

Millen, S.V. (1986) Northern, primitive tergipedid nudibranchs, with a description of a new 
species from the Canadian Pacific. Can. J. Zool., $64,1356-1362$.

Miller, M.C. (1977) Aeolid nudibranchs (Gastropoda: Opisthobranchia) of the family Tergipedidae from New Zealand waters. Zool. J. Linn. Soc., 6o, 197-222.

MolluscaBase (2020). Guyvalvoria Vayssière, 1906. Accessed through: World Register of Marine Species at: https://www.marinespecies. org/aphia.php? $\mathrm{p}=$ taxdetails\&id=391305 on 2020-09-23

NHM. (2020) Eolis concinna 1858.5.28.186. Accessed through https://data.nhm. ac.uk/object/ae 7 bagbb-504e-4aa3-aa6e-

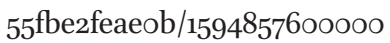

Nordsieck, F. (1972) Die europäischen Meeresschnecken (Opisthobranchia mit Pyramidellidae; Rissoacea), vom Eismeer bis Kapverden, Mittelmeer und Schwarzes Meer. Gustav Fischer Verlag, Stuttgart.

Nylander, J.A., Ronquist, F., Huelsenbeck, J.P. \& Nieves-Aldrey, J.L. (2004) Bayesian phylogenetic analysis of combined data. Syst. Biol., 53, 47-67.

Odhner, N.(1907) Northern and Arctic invertebrates in the collection of the Swedish state museum. Det Kongelige. Norske Viden. Selsk. Skrift., 41, 1-114.

Odhner, N. (1922) Norwegian opisthobranchiate Mollusca in the collections of the Zoological Museum of Kristiania. Nyt Mag. Naturvidensk., $60,1-47$.

Odhner, N. (1926) Die Opisthobranchien. Further Zool. Res. Swed. Antar. Exped. 1901-1903 under the direction of Dr. Otto Nordenskjold, 2, 1-10o.

Odhner, N. (1929) Aeolidiiden aus dem nördlichen Norwegen. Tromsø Mus. Aarsheft., 50, 1-22

Odhner, N. (1939) Opisthobranchiate Mollusca from the western and northern coasts of Norway. Det Kong. Norsk. Vidensk. Selsk. Skrift., $1,1-93$.

Odhner, N. (1944) Mollusca: Nudibranchia and Scaphopoda with zoogeographical remarks and explanations. Sci. Res. Norw. Antar. Exped. 1927-1928, 21, 1-48.
Odhner, N. [in Franc A.] (1968) Sous-classe des opisthobranches. In: Fischer E., Franc A., Martoja M., Termier G. \& Termier H. (Eds) Traite de zoologie. Anatomie, systematique, biologie. Tome V, Mollusques gasteropodes et scaphopodes, 6o8-893.

O'Donoghue, C.H. (1922) Notes on the nudibranchiate Mollusca from the Vancouver Island region. III. Records of species and distribution. Trans. R. Can. Inst., 14, 145-167.

Palumbi, S.R., Martin, A.P., Romano, S., McMillan, W.O., Stice, L. \& Grabowski, G. (2002) The simple fool's guide to PCR. Honolulu: University of Hawaii. Papu, A., Undap, N., Martinez, N.A., Segre, M.R., Datang, IG, Kuada, R.R., Perin, M., Yonow, N. \& Wägele, H. (2020). First study on marine Heterobranchia (Gastropoda, Mollusca) in Bangka Archipelago, North Sulawesi, Indonesia. Diversity, 12: 5 .

Picton, B.E. \& Morrow, C. (1994) A field guide to the nudibranchs of the British Isles. London, Immel Publishing.

Poore, G.C.B. \& Bruce, N.L. (2012) Global diversity of marine isopods (Except Asellota and crustacean symbionts). PLoS ONE, 7(8), e43529. Pruvot-Fol, A. (1954) Mollusques Opisthobranches. Faune de France, 58, 1-46o.

Puillandre, N., Lambert, A., Brouillet, S. \& Achaz, G. (2012) ABGD, Automatic barcode gap discovery for primary species delimitation. Mol. Ecol., 21, 1864-1877.

Puslednik, L. \& Serb, J.M. (2008) Molecular phylogenetics of the Pectinidae (Mollusca: Bivalvia) and effect of increased taxon sampling and outgroup selection on tree topology. Mol. Phylogenet. Evol., 48, 1178-1188.

Qiu, B. (2001) Kuroshio and Oyashio Currents. In: Encyclopedia of Ocean Sciences, pp.1413 -1425.

Roberts, C.M., McClean, C.J., Veron, J.E., Hawkins, J.P., Allen, G.R., McAllister, D.E., Mittermeier, C.G., Schueler, F.W., Spalding, M., Wells, F., Vynne, C. \& Werner, TB. (2002) Marine biodiversity hotspots and conservation priorities for tropical reefs. Science, 295, 1280-1284. 
Roginskaya, I.S. (1963) Cuthona marisalbi n. sp. - a new nudibranch mollusc from the White Sea. Proc. Kandalakshsky Nat. Reserv., 4, 258-265.

Roginskaya, I.S. (1987) Order Nudibranchia Blainville, 1814. In: Molluscs of the White Sea. Keys to the Fauna of USSR, 151, 155-201.

Ronquist, F., Teslenko, M., van der Mark, P., Ayres, D.L., Darling, A., Höhna, S., Larget, B., Liu, L., Suchard, M.A. \& Huelsenbeck, J.P. (2012) MrBayes 3.2: Efficient Bayesian phylogenetic inference and model choice across a large model space. Syst. Biol., 61, 539-542.

Stamatakis, A., Hoover, P. \& Rougemont, J. (2008) Rapid bootstrap algorithm for the RAxML webservers. Syst. Biol., 75, 758-771.

Stejneger, L. (1936) Georg Wilhelm Steller. The pioneer of Alaskan Natural History. Harvard University Press, Cambridge, Massachusets.

Swennen, C. (1961) Data on distribution, reproduction and ecology of the nudibranchiate molluscs occurring in the Netherlands. Neth.J. Sea Res., 1, 191-240.

Tanaka,T.(2017) RussianAinuleadercalls forgreater respect. Nikkei, Asian Review. Accessed through https://asia.nikkei.com/Politics/Russian-Ainuleader-calls-for-greater-respect2

Thompson, T.E. \& Brown, G.H. (1984) Biology of opisthobranch molluscs. Vol. 2. The Ray Society Publishing, London.
Thorson, G. (1950) Reproductive and larval ecology of marine bottom invertebrates. Biol. Rev. Cambr. Philos. Soc., 25, 1-45.

Tsunemoto, T. (2019) Overview of the Ainu Policy Promotion Act of 2019. Hokkaido University. Accessed through https:// fpcj.jp/wp/wp-content/uploads/2019/11/ b8102b519c7b7c4a4e129763f23ed69o.pdf

Valdés, A., Moran, A.L. \& Woods, H.A. (2012) Revision of several poorly known Antarctic aeolid nudibranch species (Mollusca, Gastropoda) with the description of a new species. J. Mar. Biol. Assoc. UK, 92, 1161-1174.

Waters, V.L. (1966) Food preference and feeding behaviour of four nudibranchs. Ann. Rep. Amer. Malacol. Union, Pacific Division, 63.

Williams, G. \& Gosliner, T. (1979) Two new species of nudibranchiate molluscs from the West Coast of North America, with a revision of the family Cuthonidae. Zool. J. Linn. Soc., 67, 203-223.

Wszolek, Z.K., Williams, D.P. \& Kyle, R.A. (1990) Benedykt Dybowski-physician, explorer, scientist, political prisoner. Mayo Clinic Proceed., 65, 1381.

RECEIVED: 11 AUGUST 2O2O | REVISED AND ACCEPTED: 28 OCTOBER 2020

EDITOR: B.W. HOEKSEMA 


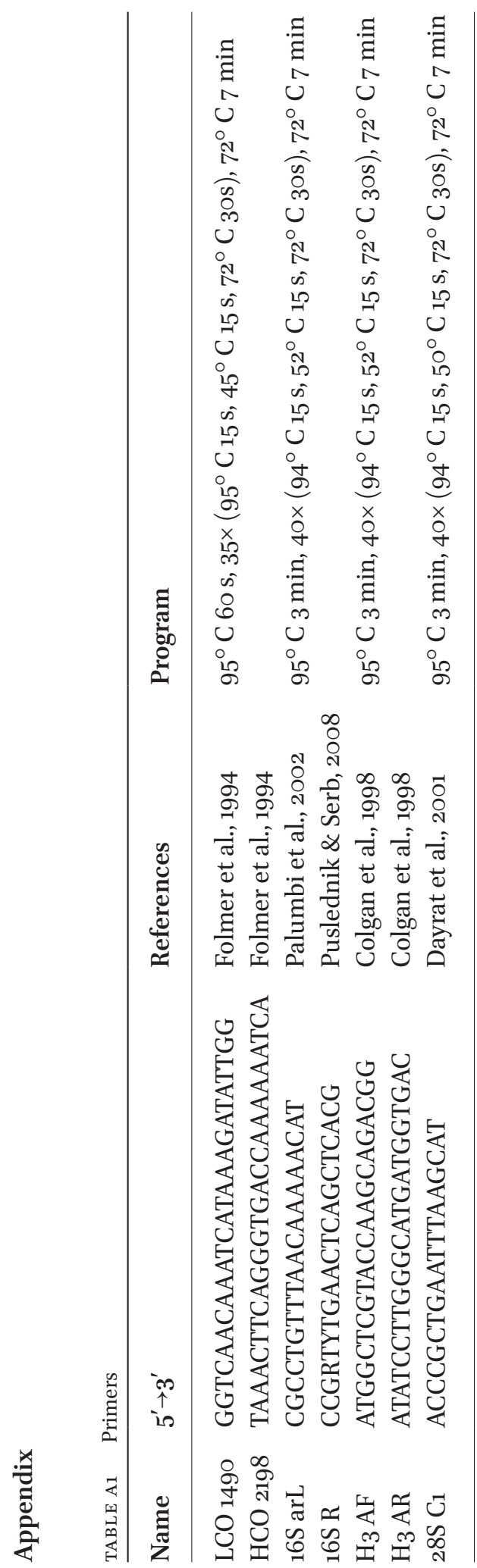




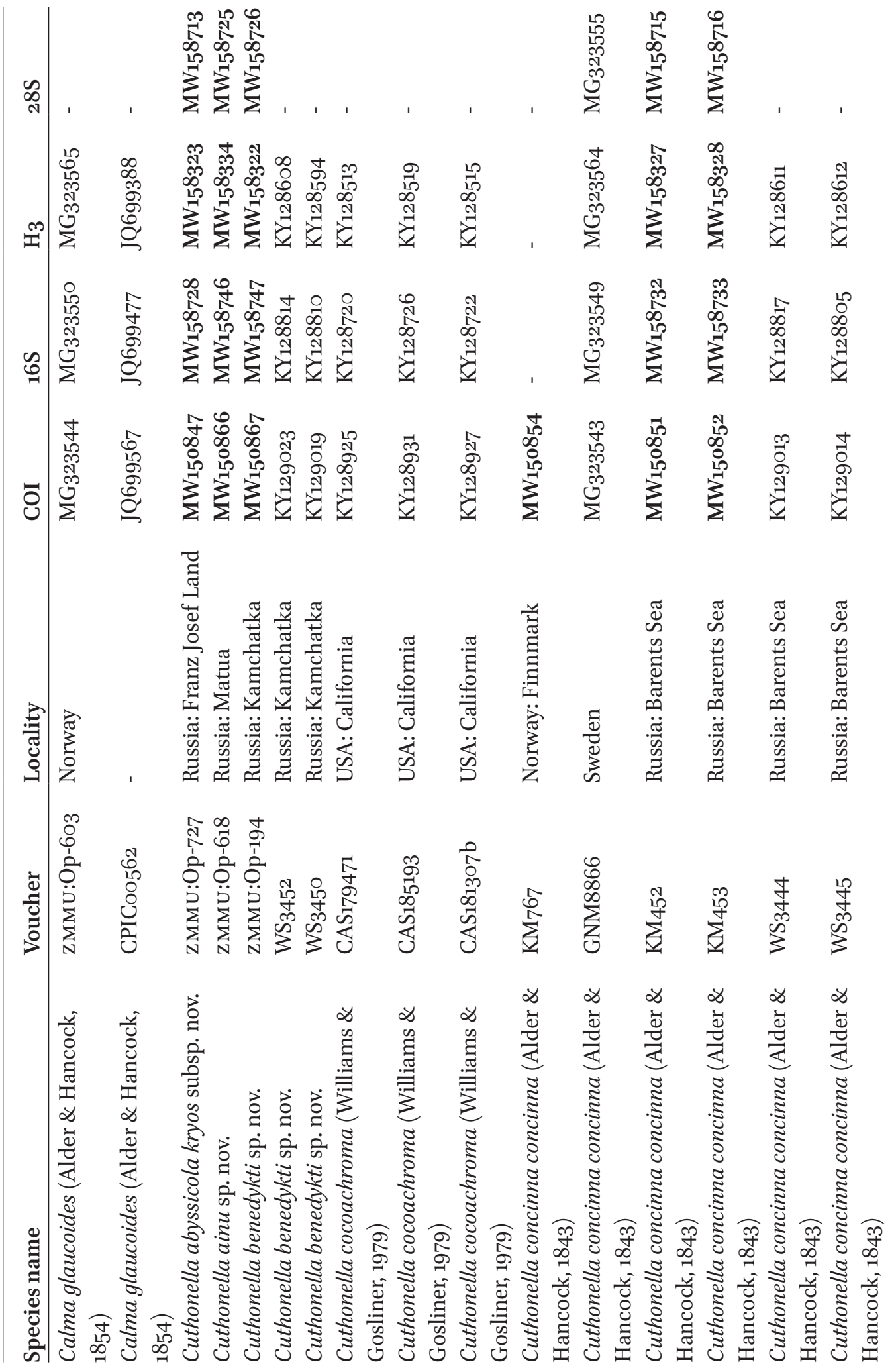




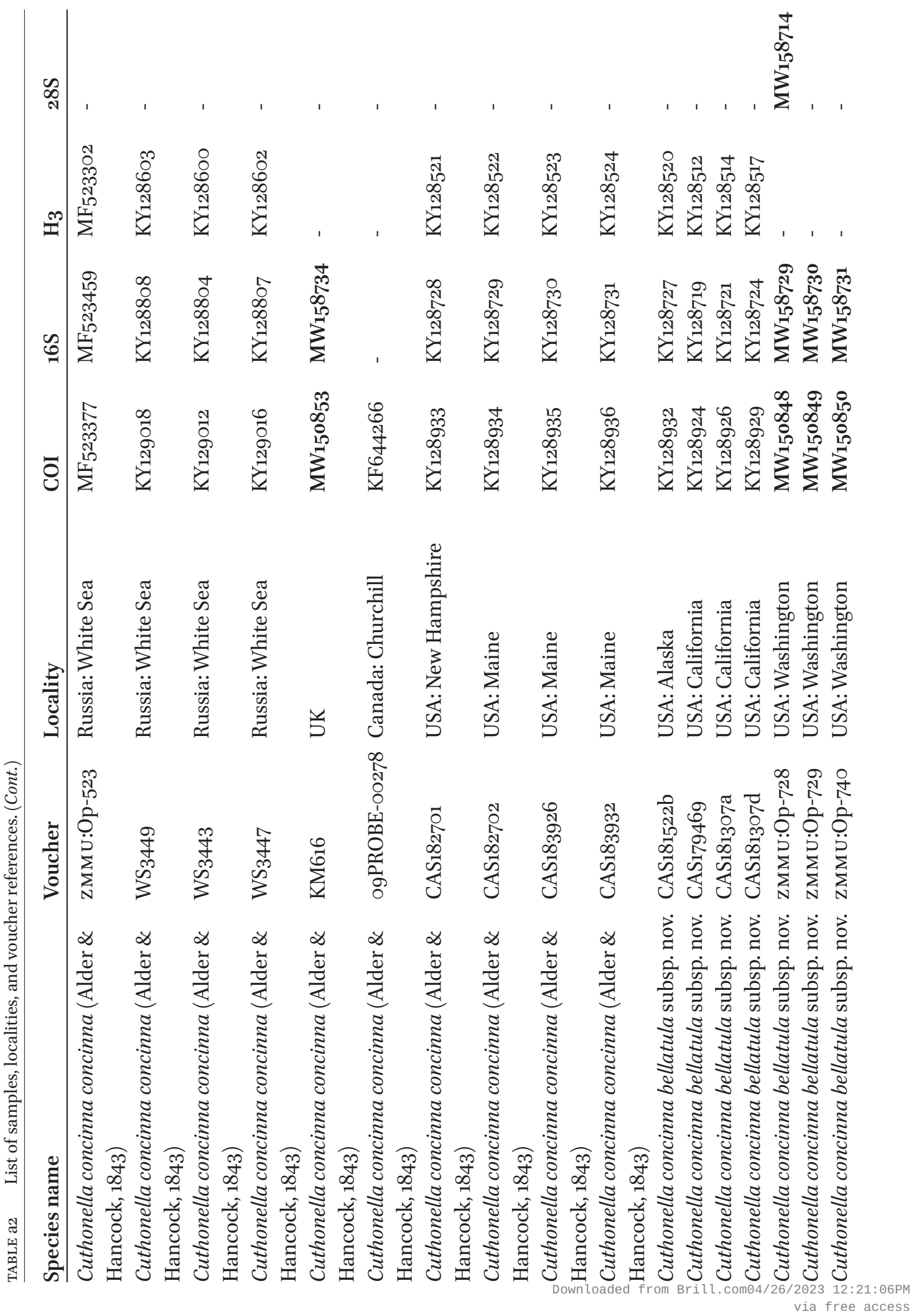




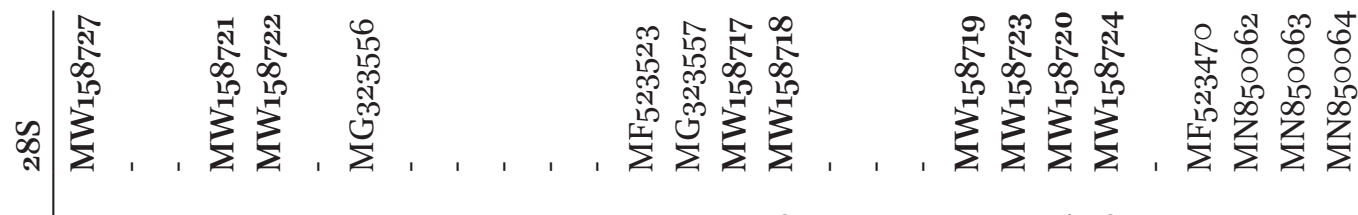

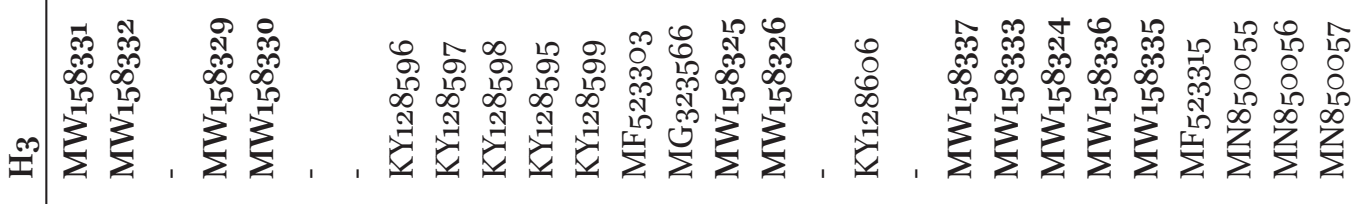

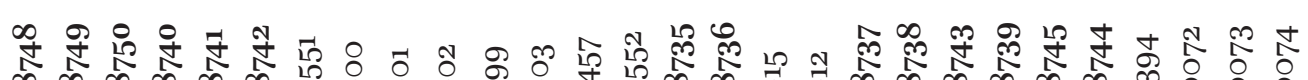

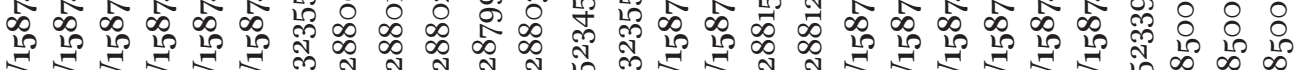

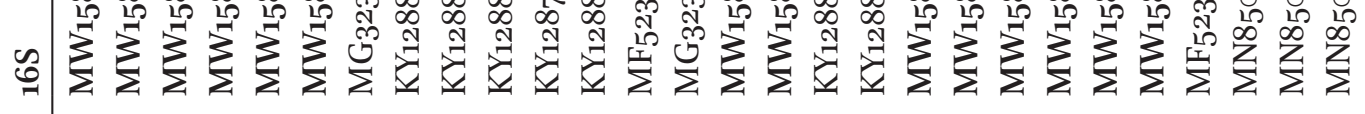

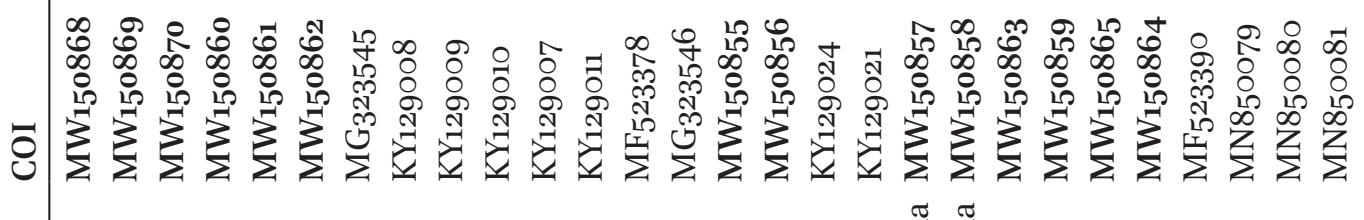

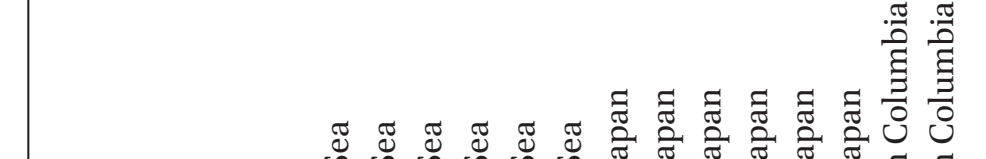

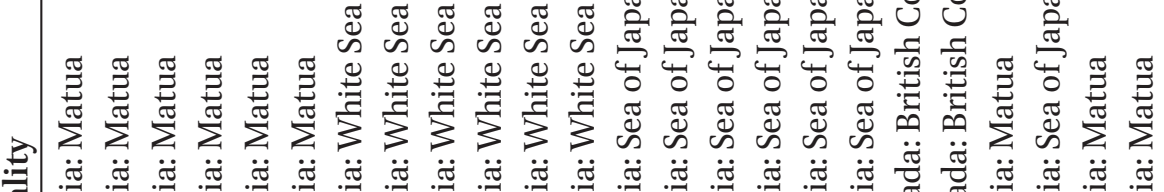

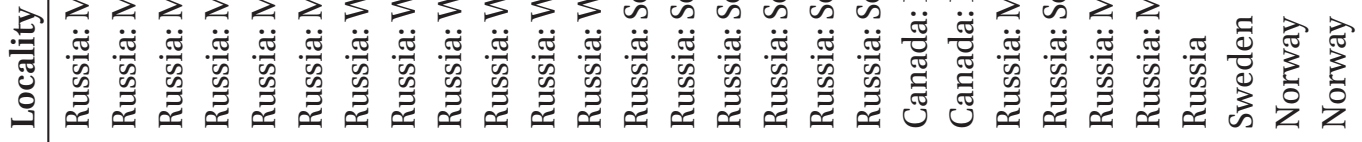

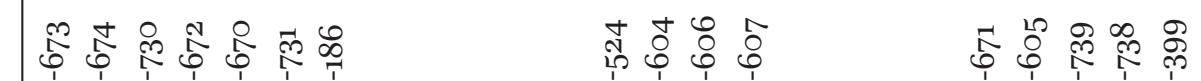

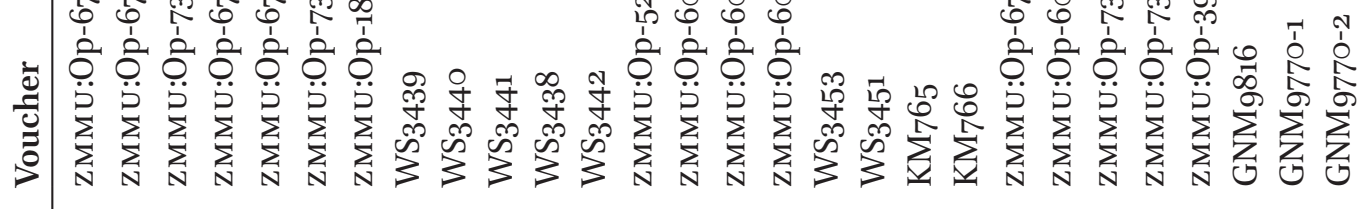

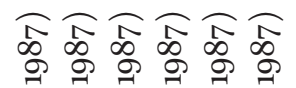

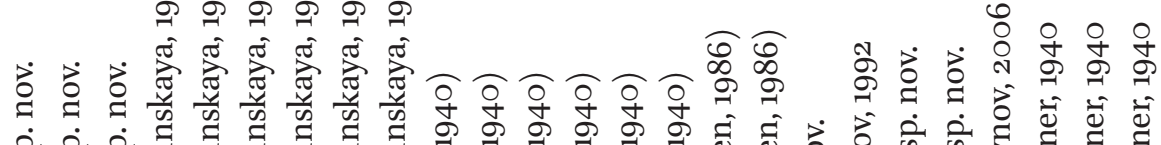

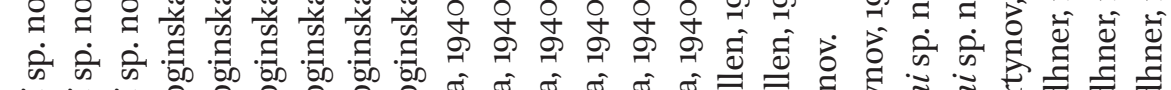

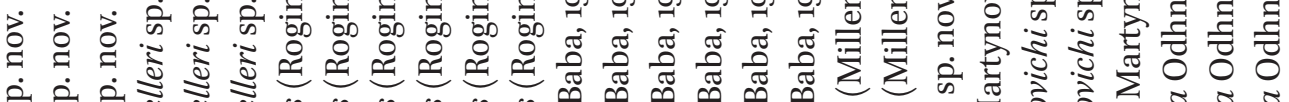
के

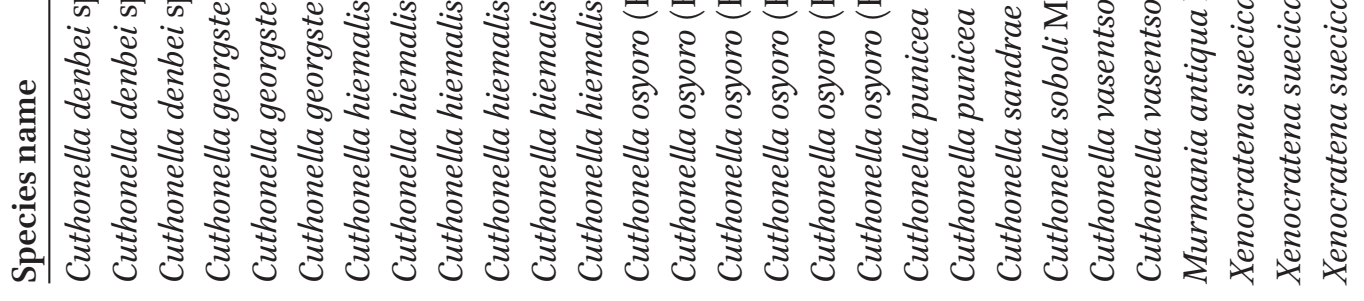

